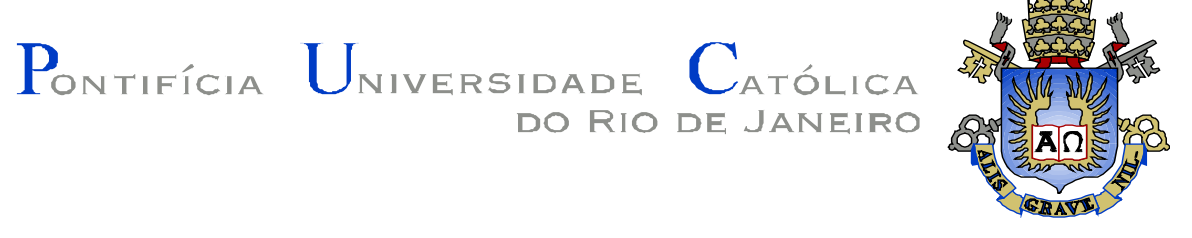

Eduarda Naidel Barboza e Barbosa

\title{
Parkinson's Disease: Innovative Perspectives in Diagnosis and Treatment
}

Thesis presented to the Programa de Pós-gradução em Psicologia of PUC-Rio in partial fulfillment of the requirements for the degree of Doutor em Psicologia Clínica.

Advisor Prof(a) Helenice Charchat-Fichman 


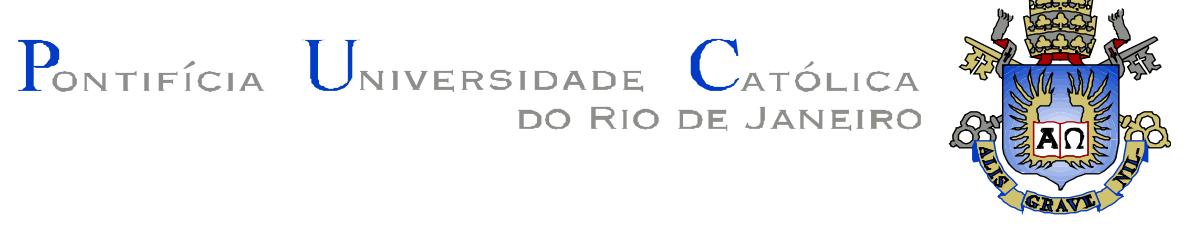

Eduarda Naidel Barboza e Barbosa

\section{Parkinson's Disease: Innovative Perspectives in Diagnosis and Treatment}

Thesis presented to the Programa de Pós-graduação em Psicologia of PUC-Rio in partial fulfillment of the requirements for the degree of Doutor em Psicologia. Approved by the Examination Committee.

Profa. Helenice Charchat Fichman

Advisor Departamento de Psicologia - PUC-Rio

Prof. Jesus Landeira Fernandez Departamento de Psicologia - PUC-Rio

Prof. Carlos Eduardo Lourenço dos S. Nórte Instituto de Psicologia - UERJ

Prof. José Augusto Nasser dos Santos INTO/RJ

Profa. Mariana Spitz Departamento de Neurologia - HSE/RJ 
All rights reserved.

\section{Eduarda Naidel Barboza e Barbosa}

$\mathrm{PhD}$ in Clinical Psychology - Pontifical Catholic University of Rio de Janeiro 03/2020 - CNPq scholarship. Specialist in Cognitive Behavioral Therapy - Pontifical Catholic University of Rio de Janeiro 08/2019. Specialist in Gerontology - Rio de Janeiro State University 12/2014. Graduated in Psychology - Federal University of Rio de Janeiro 12/2012.

Bibliografic data

Barbosa, Eduarda Naidel Barboza e

Parkinson's disease : innovative perspectives in diagnosis and treatment / Eduarda Naidel Barboza e Barbosa ; advisor: Helenice Charchat-Fichman. -2020.

102 f. : il. color. ; $30 \mathrm{~cm}$

Tese (doutorado)-Pontifícia Universidade Católica do Rio de Janeiro, Departamento de Psicologia, 2020.

Inclui bibliografia

1. Psicologia - Teses. 2. Doença de Parkinson. 3. Avaliação neuropsicológica. 4. Estimulação cerebral profunda. 5. CompCog. I. Charchat-Fichman, Helenice. II. Pontifícia Universidade Católica do Rio de Janeiro. Departamento de Psicologia. III. Título. 


\section{Acknowledgments}

Deus, agradeço por me dar a oportunidade de me dedicar à pesquisa científica e ao atendimento assistencial. Sinto-me honrada em poder oferecer à população nossos achados para auxiliar os profissionais de saúde no cuidado ambulatorial e/ou clínico.

Aos meus pais que apoiaram todas as minhas escolhas e estiveram ao meu lado torcendo pelo meu sucesso.

Aos meus amigos que foram essenciais nos momentos de folga e descanso.

Às minhas companheiras da 219: mestrandas e doutorandas, obrigada pelas conversas, almoços e trocas de mensagens - desesperadas e de conforto. Sem vocês essa jornada de 4 anos (contando apenas o doutorado) teria sido muito mais dura e difícil. Principalmente na reta final, a ajuda de vocês foi essencial para que esse trabalho fosse finalizado. Feliz por sermos um grupo que torce uma pela outra, mesmo dentro desse ambiente altamente competitivo. Que nossa amizade permaneça mesmo após cada uma seguir o seu caminho profissional.

À professora Helenice Charchat Fichman, agradeço pela disponibilidade e oportunidade em me auxiliar durante esses anos no desenvolvimento desse projeto tão interessante. Participar do grupo de pesquisa e estudo em neuropsicologia clínica desde 2012 na PUC-Rio foi essencial para o meu crescimento profissional e pessoal.

Ao doutor José Augusto Nasser dos Santos, que honra conhecê-lo. Obrigada por ceder seus pacientes, seu consultório e seus conselhos. Serei eternamente grata por me incentivar a levar meus achados a outros patamares... Conheci muitas cidades, pesquisas e profissionais graças aos congressos internacionais nos quais apresentei trabalho. Espero que continuemos trocando ideias, pacientes e projetos.

À doutora Mariana Spitz agradeço a disponibilidade e colaboração durante todo o processo de submissão do projeto no Hospital Federal dos Servidores do Estado e na seleção dos pacientes para avaliação. Além disso, fico feliz de podermos trabalhar juntas e espero que essa parceria se perpetue por muitos anos.

Aos pacientes do ambulatório de Neurologia do Hospital Federal dos Servidores do Estado e do consultório do dr José Nasser deixo o meu agradecimento por disponibilizarem seu tempo e energia para as (longas) avaliações neuropsicológicas. Muitos têm o entendimento do que é a pesquisa e, inclusive, cito um dos pacientes do ambulatório que escreveu para mim "Eu tenho a agradecer por pessoas como você se dedicar a ciência" e eu respondo devolvendo esse agradecimento aqueles que aceitaram participar e disponibilizar seus resultados à ciência.

À PUC-Rio e CNPq pela estrutura e auxílios concedidos que permitiram que o projeto saísse do papel e pudesse ser realizado. À Marcelina por ser sempre atenciosa e prestativa, aos cozinheiros do bandejão por sua criatividade e cardápio vegetariano delicioso e ao RDC onde pude imprimir boa parte do material necessário para a pesquisa. 


\section{Abstract}

Barbosa, Eduarda Naidel Barboza e; Charchat-Fichman, Helenice (Advisor). Parkinson's Disease: Innovative Perspectives in Diagnosis and Treatment. Rio de Janeiro, 2020. 102p. Tese de Doutorado - Departamento de Psicologia, Pontifícia Universidade Católica do Rio de Janeiro.

Parkinson's disease (PD) is considered the second most common neurodegenerative disease and its motor characteristics are much better known than non-motor ones, but functional impairment is present in almost all cases. Deep Brain Stimulation (DBS), which consists of electrical stimulation of subcortical structures to decrease or stop motor symptoms, has been used as a tool for greater control of motor symptoms and is gaining ground in studies with non-motor symptoms. It is for this reason that a systematic review was carried out to find out the instruments used in the neuropsychological assessment of people with PD who underwent DBS surgery in subtalamic nuclei (STN) and to investigate whether cognitive effects would arise after surgery. In addition, a computerized neuropsychological battery, the CompCog, was validated for people with PD from a public hospital in the Rio de Janeiro city and was also used to compare $\mathrm{ON}$ and $\mathrm{OFF}$ stages of 9 patients, from a private clinic, who did the implementation of the DBS-STN. With systematic reviews, it was possible to develop a neuropsychological assessment protocol, later used in empirical studies and to verify that verbal fluency was the aspect that showed the greatest difference between the ON and OFF stages of patients with ECP-NST. In the clinical validation study of CompCog it was possible to establish cutoff points for people with PD and in the comparison study between ON and OFF stages of people with PD and ECP-NST it was possible to identify that the time variables such as mean reaction time and total time, were able to differentiate the two stages, ON and OFF, of the sample of 9 people in the subtests of incidental memory, episodic memory and inhibitory control, in addition to showing a tendency to differentiate in attention, processing speed and episodic memory.

\section{Keywords}

Parkinson's Disease; Cognition; Deep Brain Stimulation; Validation of a computerized neuropsychological battery 


\section{Resumo}

Barbosa, Eduarda Naidel Barboza e; Charchat-Fichman, Helenice. Doença de Parkinson: Perspectivas Inovadoras em Diagnóstico e Tratamento. Rio de Janeiro, 2020. 102p. Tese de Doutorado - Departamento de Psicologia, Pontifícia Universidade Católica do Rio de Janeiro.

A doença de Parkinson (DP) é considerada a segunda doença neurodegenerativa mais comum e suas características motoras são muito mais conhecidas que as não motoras, mas o comprometimento funcional está presente em quase todos os casos. A Estimulação Cerebral Profunda (ECP), que consiste na estimulação elétrica de estruturas subcorticais para diminuir ou cessar os sintomas motores, tem sido usada como uma ferramenta para maior controle dos sintomas motores e está ganhando terreno em estudos com sintomas não motores. É por esse motivo que foi realizada uma revisão sistemática para conhecer os instrumentos utilizados na avaliação neuropsicológica de pessoas com DP submetidas à cirurgia ECP nos núcleus subtalâmicos (NST), além de investigar também se surgiriam efeitos cognitivos após a cirurgia. Além disso, uma bateria neuropsicológica computadorizada, a CompCog, foi validada para pessoas com DP de um hospital público da cidade do Rio de Janeiro e também foi usada para comparar os estágios ON e OFF de 9 pacientes, de uma clínica privada, que fizeram a implantação da ECP-NST. Com as revisões sistemáticas foi possível elaborar um protocolo de avaliação neuropsicológica, posteriormente utilizado nos estudos empíricos e verificar que a fluência verbal foi o aspecto que apresentou maior diferença entre os estágios ON e OFF dos pacientes com ECP-NST. No estudo de validação clínica da CompCog foi possível estabelecer pontos de corte para as pessoas com DP e no estudo de comparação entre estágios ON e OFF de pessoas com DP e ECP-NST foi possível identificar que as variáveis de tempo como tempo médio de reação e tempo total, foram capazes de diferenciar os dois estágios, ON e OFF, da amostra de 9 pessoas nos subtestes de memória incidental, memória episódica e controle inibitório, além de apresentar uma tendência à diferenciação na atenção, velocidade de processamento e memória episódica.

\section{Palavras-chave}

Doença de Parkinson, Cognição, Estimulação Cerebral Profunda, Validação de Bateria Neuropsicológica Computadorizada 


\section{Table of contents}

$\begin{array}{llr}1 & \text { Background } & 10\end{array}$

2 Objectives 12

3 Articles section 13

Article 1: Systematic review of neuropsychological instruments used in subthalamic nucleus deep brain stimulation in Parkinson's disease patients

Article 2: How Is Cognition on Subthalamic Nucleus Deep Brain Stimulation Parkinson's Disease Patients? A 2007 to 2017 Systematic Review

Article 3: CompCog has high accuracy to identify cognitive symptoms in

Article 4: What cognitive functions discriminate ON e OFF stages in people with Parkinson Disease after Subtalamic Nucleos Deep Brain Stimulation

4 Final Considerations

$5 \quad$ References 


\section{List of figures}

\section{Article 1}

Figure 1 - Articles research fluxogram

\section{Article 2}

Figure 1 - Articles research fluxogram

\section{Article 3}

Figure 1 - ROC Curve -sensibility and specificity for Choice Reaction Time Median Reaction Time and Total Time for PD versus CG

Figure 2 - ROC Curve - sensibility and specificity for Implicit Learning Test

Figure 3 - ROC Curve - sensibility and specificity for Visuospatial ShortTerm Memory, Stroop Test and Survey Median Reaction Time and Total Time for $\mathrm{PD}$ versus $\mathrm{CG}$

Figure 4 - ROC Curve - sensibility and specificity for Face Recognition and Memory Median Reaction Time and Total Time for PD versus CG 


\section{List of tables}

\section{Article 1}

Table 1 - List of articles included in the systematic review criteria

Table 2 - List and Quantity of Instruments used separated by Domains

Table 3 - Instruments most used pre and post DBS

\section{Article 2}

Table 1 - List of articles included in the systematic review criteria

Table 2 - Domains evaluated and effects found in each article

\section{Article 3}

Table 1 - CompCog subtests, variables and description

Table 2 - Socio-demographic data

Table 3 - Neuropsychological profile

Table 4 - Description and comparison of CompCog results of both groups

Table 5 - Cut-off scores of the most discriminative significant variables

\section{Article 4}

Table 1 - CompCog subtests, variables and description

Table 2 - Patients social and clinical information

Table 3 - Neuropsychological profile on ON stage 


\section{BACKGROUND}

Parkinson's disease (PD) was first described in 1817 by James Parkinson, and, just 47 years later, was called Parkinson's disease. It is considered the second most common neurodegenerative disease, preceded only by Alzheimer's Disease (AD) (Pavão, 2007; Rita, 2012; de Paixão et al, 2016). Its motor characteristics are much better known than non-motor ones, but functional impairment is present in practically all cases (Machado \& Reppold, 2015; Pavão, 2007; Werneck, 2010; Heluani, 2014). Patients with PD present, in addition to motor impairments, nonmotor impairments, such as a variety of neuropsychiatric symptoms (depression and psychotic symptoms) (Aarsland et al, 2009; Navarro-Peternella \& Marcon, 2012). When it was described, it was believed that cognition was preserved in PD, but current research (Nombela et al, 2014; Ding et al, 2015) brings reports of cognitive decline.

The PD diagnosis is made through clinical criteria by trained professionals, such as neurologists. These criteria are based on the identification of clinical manifestations, pure motor symptoms. The definitive diagnosis can only be made with necropsy. The most widely used criteria are those of the UK Parkinson's Society Brain Bank (Litvan et al, 2012) and in 2015 the Movement Disorders Society launched new criteria (MDS, 2015).

The pathological marker of this disease is deterioration in the substantia nigra pars reticulata in addition to Lewy bodies accumulation - protein aggregates (Melo et al, 2007). PD is considered the result from the degeneration of dopaminergic neurons, resulting in a consequent reduction of dopamine levels in the substantia nigra, a region located in the upper part of the brain stem, impairing the functioning of motor circuits and - implicit procedural learning (Pavão, 2007; Rita, 2012; de Paixão et al, 2016). Pathological changes take an upward path, from the brain stem to neurons of the substantia nigra and from there to cortical areas (Melo et al, 2007). The reduction in the primary motor activation, pre-motor and supplementary area are also possible causes of PD symptoms. This occurs due to an excessive excitatory discharge from the subthalamic nucleus that promotes hyperactivity of the internal pale globe and/or pars reticulata substantia nigra (Nasser, 2002). 
The occurrence of PD is more frequent in individuals aged between 85 and 90 (Driver et al, 2009), but it is also observed below 40 and above 70 years old (Silva and Nakamura, 2013), with the degenerative and the silent development start long before reaching these age groups. Silva and Nakamura (2013) estimate 1.5 to 2 individuals for every 1000 over 60 years of age will have the disease. Studies (de Lau \& Breteler, 2006; Toulouse \& Sullivan, 2008) claim that the number of cases tends to double by 2050 . As a result, it is necessary as soon as possible to develop a neuropsychological assessment protocol to establish a profile of commitment within PD.

Losses in cognitive functions such as implicit memory, executive function, visuospatial skills and language are increasingly attracting attention in the current literature (Rita, 2012). One in three PD patients has cognitive impairment at or shortly after diagnosis, with progressive worsening or even causing dementia in the later stages (Nombela et al, 2014), but cognitive changes are common in nondemented PD patients (Schneider, Sendek and Yang, 2015).

In addition to pharmacological and therapeutic treatment, there may be an indication for surgical intervention. One of these methods is deep brain stimulation (DBS), targeting the subthalamic nucleus (STN) or globus pallidus (GPi), which consists of electrical stimulation of subcortical structures. The main objective of the DBS is to control motor function (Aguilar, Soto \& Esguerra, 2011). The reason why STN is chosen is due to the possibility of decreasing the dose of medications and, consequently, reducing adverse effects, but there is controversy in the literature. A macro electrode is implanted in the STN and then a microelectrode operated by a neurostimulator that creates a closed circuit by sending electrical stimulation to specific areas of the brain that control movement, blocking the abnormal nerve signals that cause the tremor and the symptoms of PD. The DBS circuit has 3 components: the electrode that is inserted through a small opening in the skull and implanted in the brain, the extension that is a wire that runs from the stimulation area in the brain to the shoulder, under the skin, connecting to the neurostimulator that is implanted near the collarbone or, in some cases, in the abdomen. DBS works by inhibiting or blocking GPi or STN activity the latter being more advantageous - due to its high frequency, reversing its 
abnormal functionality, but without the risks and complications of bilateral ablation (Nasser, 2002).

The literature points to an evident motor and quality of life improvement after DBS in patients with PD, however studies dedicated to the relationship between STN-DBS and cognitive functioning are divergent - generating the motivation for this investigation. In this context, it becomes propitious to validate an instrument that allows a more specific neuropsychological assessment of aspects not considered for this population.

\section{OBJECTIVES}

According to the background presented, first this study wants to investigate the use of certain instruments in studies with PD patients with STNDBS to propose a protocol that addresses the cognitive functions involved in the disease, also wants to analyze the effects on cognition in people with PD and STN-DBS. The second part of this thesis is composed of two studies: the first seeks to validate a computerized neuropsychological battery, CompCog, for people with $\mathrm{PD}$ and the second one wants to compare $\mathrm{ON}$ and $\mathrm{OF}$ stages in cognitive performance on STN-DBS patients using the protocol proposed previously and CompCog. 


\title{
ARTICLES SECTION
}

\author{
ARTICLE 1 \\ Barbosa E. N. B., Charchat-Fichman H. Systematic review of neuropsychological \\ instruments used in subthalamic nucleus deep brain stimulation in Parkinson's \\ disease patients. Dementia and Neuropsychologia, 2019, v. 13, n. 2, p. 162-171.
}

\section{ABSTRACT}

Introduction: In addition to drug treatment, surgical intervention represents an alternative to PD patients with motor deficits. The most common intervention is subthalamic nucleus deep brain stimulation (STN-DBS). It is extremely important to perform a neuropsychological assessment in patients with STN-DBS, not only to identify losses related to the disease, but also to compare influence on cognition both pre and postoperatively. Objective: the objective of this systematic review was to investigate the instruments frequently used in studies related to STN-DBS in PD patients. Methods: articles were retrieved from Medline/ PubMed databases published in the 2007-2017 period using PRISMA criteria. Results: after analyzing 27 articles, the absence of a specific evaluation protocol for PD with STN-DBS was evident. Conclusion: non-motor symptoms are not given due importance in neuropsychological assessments. It is crucial to acknowledge that these symptoms have a major impact on the quality of life of patients. Greater engagement in assessing these aspects is required, in order to bridge the gaps in research.

Keywords: Parkinson's disease, deep brain stimulation, neuropsychological instruments, neuropsychological assessment. 


\section{Systematic review of neuropsychological instruments used in subthalamic nucleus deep brain stimulation in Parkinson's disease patients}

\section{INTRODUCTION}

Parkinson's disease (PD) is considered to be the second most common neurodegenerative disease, preceded only by Alzheimer's disease (AD) ${ }^{1,2}$. PD's motor characteristics are much better known than non-motor ones, but the patient also presents functional impairment ${ }^{1,3-5}$. When PD was described, it was believed that cognition was preserved, but current research ${ }^{6,7}$ brings reports of cognitive decline.

Besides drug treatment, it is possible to use surgical intervention in some cases. One of these methods is deep brain stimulation (DBS) consisting of the electrical stimulation of subcortical structures. The main objective of DBS is motor control of symptoms; however, the stimulated areas are also potentially able to stimulate some cognitive functions secondarily ${ }^{8}$.

Studies usually promote cognitive screening in patients to characterize the sample and identify the impairments to be analyzed. However, comparing cognitive data from different populations and through different tests can produce some conflicts in the literature, mainly because it is used screening instruments that do not have the sensitivity to detail cognitive functioning sufficiently ${ }^{5}$ and some of them provide different versions of the same test or use nonstandard tasks.

The objective of this review is to learn and understand the use of certain instruments in studies with PD patients with STN-DBS and to relate those findings with the literature in general. The search included articles published from January 2007 to January 2017, based on The Preferred Reporting Items for Systematic Review and Meta-Analyzes (PRISMA) criteria.

\section{METHODOLOGY}

The systematic review is a type of scientific research that aims to gather, critically evaluate and conduct a synthesis of multiple primary studies ${ }^{9}$. 
2.1 Bibliographic Survey We projected a systematic review of the literature according to the Preferred Reporting Items for Systematic Review and MetaAnalyzes (PRISMA) criteria. The following terms were used: "Deep Brain Stimulation", "DBS", "Cognitive Functions" and "Parkinson Disease" with the Boolean operator "and". We selected scientific papers published in English between January 2007 and January 2017, with comparative clinical trials in humans, in Medline / PubMed databases. Articles published before 2007, systematic reviews, case studies, books chapters and studies using animals were excluded.

2.2 Studies selection Initially, this method identified 345 responses (Figure 1). To refine the research, the following topics were selected: "Parkinson's Disease", "Subthalamic Nucleus", "Deep Brain Stimulation", "DBS", "Cognition" (263), published in the Medline / PubMed database (223) between 2007 and 2017 (195). From the material collected, we observed titles and summaries to consider studies with human clinical trials exclusively (66). Literature reviews and case studies were excluded, as well as articles containing problems in the methodology, such as not inclusion of (a) inclusion and exclusion criteria, (b) complete assessment protocol and (c) lack of pre or post-surgery assessment fulfillment (27). The researchers selected the articles independently: they considered suitable studies that (a) evaluated PD patient's cognition with STN-DBS; (b) presented the instruments and domains evaluated; and (c) presented pre and post-surgical results.

Figure 1. Articles research fluxogram 


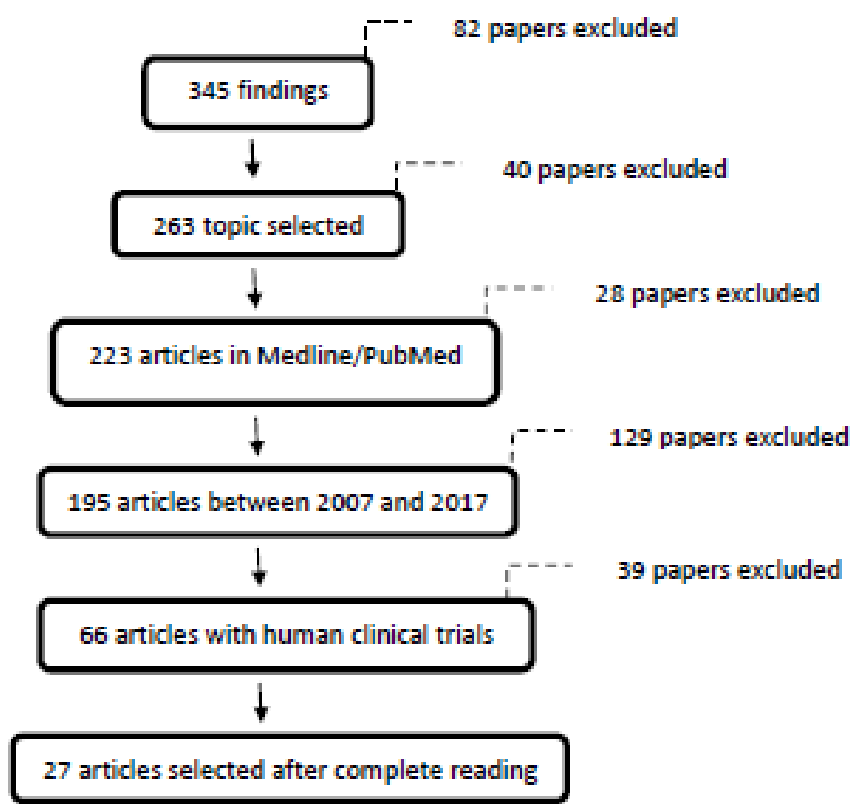

\section{RESULTS}

Following are the final list of articles that were included by the research criteria in ascending order of year, with objectives and results (Table 1), a list of instruments with quantity, separated by domains (Table 2) and a list of instruments used before and after DBS implantation to assess the cognitive aspects of the patients (Table 
Table 1. List of articles included in the systematic review criteria.

\begin{tabular}{llll}
\hline Authors and Name & Year & \multicolumn{2}{c}{ Used instruments } \\
\hline $\mathbf{1}$ Cilia et al. Brain networks 2007 & $\begin{array}{l}\text { Mini-Mental State Exam (MMSE), } \\
\text { Phonemic and Semantic Verbal Fluency } \\
\text { underlining verbal fluency decline } \\
\text { during STN-DBS in Parkinson's } \\
\text { disease: An ECD-SPECT study. }\end{array}$ & $\begin{array}{l}\text { Tasks, Wisconsin Card Sorting Test } \\
\text { (WCST), Raven's Progressive Matrices } \\
\text { (RPM) }\end{array}$ \\
&
\end{tabular}

$2 \quad$ Klempírová et al. Deep brain stimulation of the subthalamic nucleus and cognitive functions in Parkinson's disease.
2007 Mattis Dementia Rating Scale (MDRS), Weschler Memory Scale-III (WMS), Stroop Test, VFT

3 Castelli et al. Apathy and verbal 2007 RPM, Bi-Syllabic Words Repetition test fluency in STN-stimulated PD (BWR), Corsi's Block Tapping test (CBTT), patients.

WMS, Trail Making Test (TMT), Nelson Modified Card Sorting test (MCST), VTF, Beck Depression Inventory (BDI), Apathy Evaluation Scale (AES)

4 Heo et al. The effects of bilateral Subthalamic Nucleus Deep Brain Stimulation (STN-DBS) on cognition in Parkinson disease.
2008 TMT, Korean Boston Naming test (K-BNT), Rey-Kim Memory Battery, Grooved pegboard test, WCST, Stroop test, VFT, Korean Mini-Mental Status Examination (KMMSE), BDI

5 Witt et al. Neuropsychological and psychiatric changes after deep brain stimulation for Parkinson's disease: a randomised, multicentre study.
2008 UPDRS-I MDRS, German Rey's Auditory Verbal Learning Test (G-RAVLT), Weschler Adult Intelligence Scale (WAIS), Benton Visual Retention Test, Stroop test, VFT, BDI, Montgomery-Asberg Depression Rating Scale (MADRS), Beck Anxiety Inventory (BAI), Parkinson's Disease Questionnaire (PDQ-39)
6 Alberts et al. Bilateral subthalamic stimulation impairs cognitivemotor performance in Parkinson's disease patients.

\section{8 n-back task, dual task}

7 Lueken et al. Impaired performance on the Wisconsin Card Sorting Test under left- when compared to right-sided deep brain stimulation of the subthalamic nucleus in patients with Parkinson's disease.
2008 MMSE, WCST, German Hospital Anxiety and Depression Scale (HADS-D), German Apathy Evaluation Scale (AES) * 
8 Zangaglia et al. Deep brain stimulation and cognitive functions in Parkinson's disease: A three-year controlled study
2009 MMSE, long memory task, verbal span, digit span, CBTT, WCST, RPM, FVT
9 York et al. Relationship between neuropsychological outcome and DBS surgical trajectory and electrode location
2009 MMSE, RAVLT, VFT, MDRS, BDI, StateTrait Anxiety Inventory (STAI)

10 Williams et al. Deep brain stimulation plus best medical therapy versus best medical therapy alone for advanced 2009 UPDRS-I, PDQ-39, MDRS, Delis-Kaplan executive function system (D-KEFS), Weschler Abbreviate Scale Intelligence Parkinson's disease.

11 Daniels et al. Risk factors for executive dysfunction after subthalamic nucleus stimulation in Parkinson's disease
2010 MDRS, RAVLT, WAIS, BVRT, Stroop test, VFT
12 Castelli et al. Neuropsychological changes 1-year after subthalamic DBS in PD patients: A prospective controlled study
2010 RPM, Bi-Syllabix Words Repetition Test, Corsi's Block Tapping test, Paired Associate Learning, Trail Maling Test, MCST, VFT
13 Fasano et al. Motor and cognitive outcome in patients with Parkinson's disease 8 years after subthalamic implants
2010 MMSE, Corsi's Block Tapping Test, digit span forward, digit span backward, RAVLT, RPM, MWCST, VFT, Zung's depression Scale, Zung's Anxiety Scale

14 Van Wouwe et al. Deep Brain Stimulation of the Subthalamic Nucleus Improves Reward-Based Decision-Learning in Parkinson's Disease

15 Israeli-Korn et al. Subthalamic Nucleus Deep Brain Stimulation Does Not Improve Visuo-Motor Impairment in Parkinsons Disease

\section{Haruno and Kawato Task, MMSE}

2013 MMSE, BDI, VFT, Frontal Assessment Battery (FAB), Visual Analog Mood Scale, Digit Span Forward and Digit Span Backward, Finger Tapping Test, Visualmotor Coordination Task
16 Kim et al. Initial cognitive dip after subthalamic deep brain stimulation in Parkinson disease
2013 MMSE, TMT, K-BNT, Rey-Kim Memory Battery, Stroop Test, VFT, BDI 
17 Yágüez et al. Cognitive predictors of cognitive change following bilateral subthalamic nucleus deep brain stimulation in Parkinson's disease
2014 WAIS-III, Recognition Memory Test, Birt Memory and Information Processing Battery, Graded Naming Test, Visual Object and Space Perception Battery, Hayling Sentence Completion Test, Brixton Spatial Anticipation Test, VFT
18 Asahi et al. Impact of bilateral subthalamic stimulation on motor/cognitive functions in Parkinson's disease
2014 MMSE, Japanese Adult Reading Test (JART), Repeatable Battery for the Assessment of Neuropsychological Status (RBANS), WAIS-Revised
19 Rizzone et al. Long-term outcome of subthalamic nucleus DBS in Parkinson's disease: From the advanced phase towards the late stage of the disease?
2014 UPDRS-I, MMSE, RPM, Digit Span Forward, Corsi's Block Test, MWCST, VFT, RAVLT, TMT, Paired Associated Learning, Attentive Matrices, Zung's Depression Scale, Zung's Anxiety Scale, BDI, State-Trait Anxiety Inventory (STAI)

2015 MDRS, VFT, Stroop Test, TMT, MCST, MADRS, Apathy Evaluation Scale (AES)
20 Houvenaghel et al. Reduced Verbal Fluency following Subthalamic Deep Brain Stimulation: A Frontal-Related Cognitive Deficit?
21 Markser et al. Deep brain stimulation and cognitive decline in Parkinson's disease: The predictive value of electroencephalography

22 Pham et al. Self-Reported Executive Functioning in Everyday Life in Parkinson's Disease after Three Months of Subthalamic Deep Brain Stimulation
2015 MMSE, MDRS, Dem-Tech
2015 MDRS, Behavior Rating Inventory of Executive Function-Adult Version (BRIEFA), Symptom Checklist 90- Revised (SCL90-R), AES
23 Tang et al. Evidence of improved immediate verbal memory and diminished category fluency following STN-DBS in ChineseCantonese patients with idiopathic Parkinson's disease
2015 Montreal Cognitive Assessment Hong Kong version (HK-MoCA), Chinese Auditory Verbal Learning Test (CAVLT), BVRT, Chinese modified version of BNT, Hooper Visual Organization Test (HVOT), Stroop Test Chinese victoria version, VFT (semantic), BDI-II, BAI
24 Tremblay et al. The effects of subthalamic deep brain stimulation on metaphor comprehension and language abilities in Parkinson's disease
2015 MoCA, Metaphor Comprehension Task, VFT (semantic), Alternation VFT, Lexical Decision Test, Word Association Test, BDI version IA 
25 Krishnan et al. The decade after subthalamic stimulation in advanced Parkinson's disease: A balancing act.
2016 UPDRS-I, MMSE, Addenbrooke's Cognitive Examination, BDI, Parkinson's Disease Quality of Life (PDQL) Questionnaire

\section{Parkinson Neuropsychometric Dementia} Assessment (PANDA), German VFT Stimulation of the Subthalamic Nucleus Improves Lexical Switching in Parkinson's Disease Patients

27 Ventre-Dominey et al. Distinct effects of dopamine vs STN stimulation therapies in associative

2016 Conditional Associative Learning (CAL), Visual spatial Working Memory Task, Nonlearning and retention in Parkinson spatial Working Memory Task 
Table 2. List and Quantity of Instruments used separated by Domains

\begin{tabular}{|c|c|c|c|}
\hline $\mathbf{N}^{\circ}$ & $\begin{array}{l}\text { Assessed } \\
\text { Domains }\end{array}$ & Instruments & $\begin{array}{c}\mathbf{N}^{\circ} \text { of } \\
\text { articles }\end{array}$ \\
\hline 1 & $\begin{array}{l}\text { Daily Life } \\
\text { Activities }\end{array}$ & UPDRS-I Non-Motor Experiences & 3 \\
\hline \multirow[t]{2}{*}{2} & $\begin{array}{l}\text { PD Quality of } \\
\text { Life }\end{array}$ & Parkinson`s Disease Questionnaire (PDQ-39) & 2 \\
\hline & & Parkinson`s Disease Quality of Life (PDQL) & 1 \\
\hline \multirow{10}{*}{3} & & Mini-Mental State Exam (MMSE)* & 14 \\
\hline & & Mattis Dementia Rating Scale (MDRS) & 8 \\
\hline & & Raven's Progressive Matrices (RPM) & 6 \\
\hline & & Weschler Adult Intelligence Scale (WAIS-III)* & 4 \\
\hline & $\begin{array}{l}\text { Global } \\
\text { Functioning }\end{array}$ & Montreal Cognitive Assessment (MoCA)* & 2 \\
\hline & & Addenbrooke's Cognitive Examination & 1 \\
\hline & & Japanese Adult Reading Test (JART) & 1 \\
\hline & & $\begin{array}{l}\text { Repeatable Battery for the Assessment of } \\
\text { Neuropsychological Status (RBANS) }\end{array}$ & 1 \\
\hline & & Dem-Tech & 1 \\
\hline & & $\begin{array}{l}\text { Parkinson Neuropsychometric Dementia Assessment } \\
\text { (PANDA) }\end{array}$ & 1 \\
\hline
\end{tabular}

\begin{tabular}{ccc}
\hline $4 \quad \begin{array}{l}\text { Psychiatry } \\
\text { Symptoms }\end{array}$ & 1 \\
Brief Psychiatric Rating Scale (BPRS) & 1 \\
& Symptom Checklist 90- Revised (SCL-90-R) & 1 \\
\hline
\end{tabular}

Verbal Fluency Tasks - Semantic* 
$5 \quad$ Executive

Functioning

$\mathrm{N}$-back and dual task

Visual Spatial and Non-spatial Working Memory Task

Rey’s Auditory Verbal Learning Test (RAVLT)*

Corsis Block Tapping test (CBTT)

Paired Associate Learning (Wechsler Memory Scale)

4

Bi-Syllabic Words Repetition test (BWR)

2

6 Memory

$$
\text { Rey-Kim Memory Battery }
$$$$
\text { Recognition Memory Test }
$$

Birt Memory and Information Processing Battery 


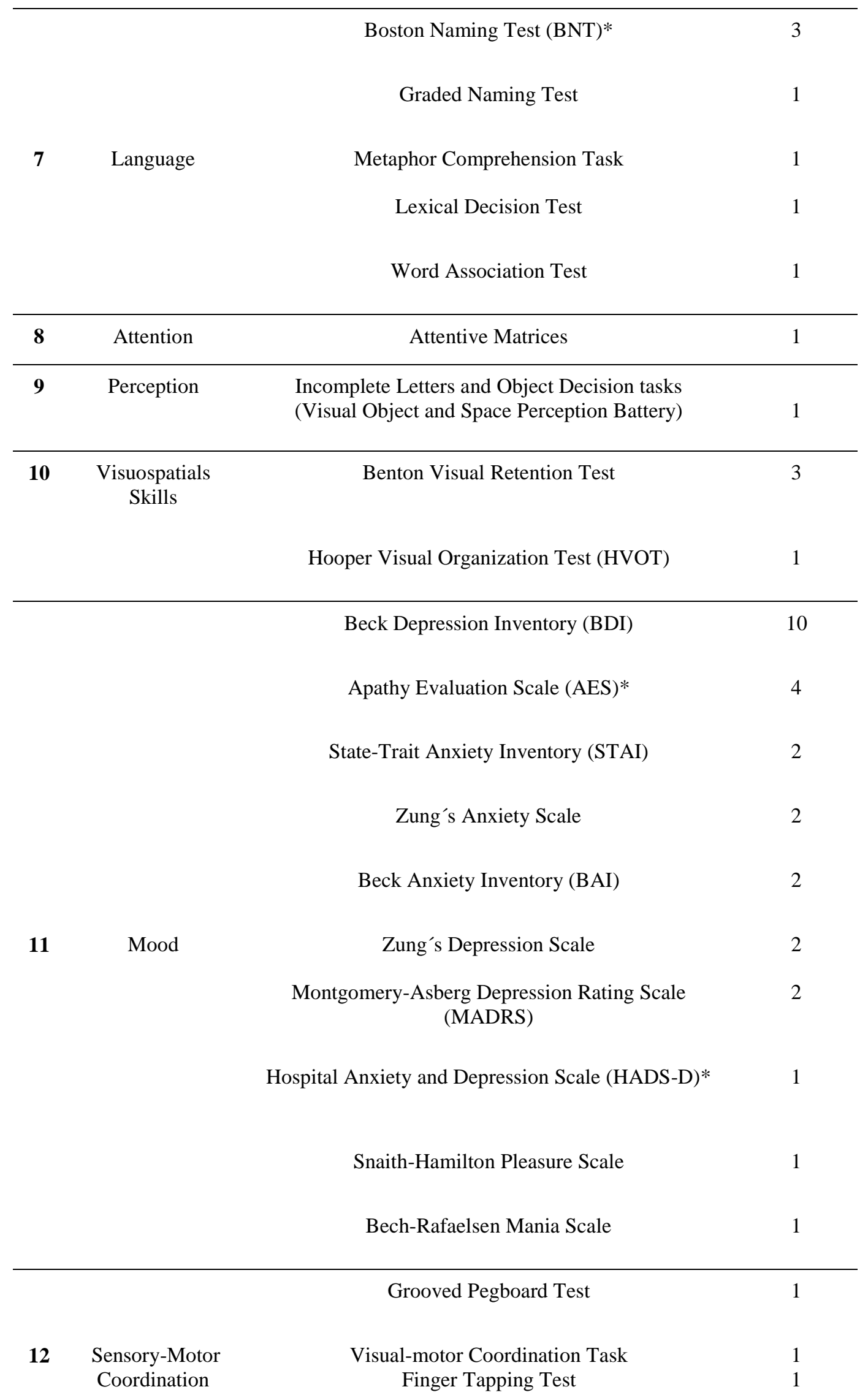


Table 3. Instruments most used pre and post DBS

\begin{tabular}{|c|}
\hline Instruments \\
\hline $\begin{array}{l}\text { Parkinson`s Disease Questionnaire (PDQ-39) } \\
\text { Parkinson`s Disease Quality of Life (PDQL) }\end{array}$ \\
\hline Mini-Mental State Exam (MMSE)* \\
\hline $\begin{array}{c}\text { Mattis Dementia Rating Scale (MDRS) } \\
\text { Raven's Progressive Matrices (RPM) }\end{array}$ \\
\hline Symptom Checklist 90- Revised (SCL-90-R) \\
\hline Verbal Fluency Tasks - Semantic* \\
\hline Verbal Fluency Tasks - Fonemic* \\
\hline Wisconsin Cards Sorting Test (WCST)* \\
\hline Stroop Test* \\
\hline Trail Making Test $(\mathrm{TMT})^{*}$ \\
\hline Digit Span Forward and Backward \\
\hline Rey's Auditory Verbal Learning test (RAVLT)* \\
\hline Corsi's Block Tapping test (CBTT) \\
\hline Rey-Kim Memory Battery \\
\hline Boston Naming Test (BNT)* \\
\hline Attentive Matrices \\
\hline $\begin{array}{l}\text { Incomplete Letters and Object Decision tasks } \\
\text { (Visual Object and Space Perception Battery) }\end{array}$ \\
\hline Benton Visual Retention Test \\
\hline Beck Depression Inventory (BDI) \\
\hline Apathy Evaluation Scale (AES)* \\
\hline State-Trait Anxiety Inventory (STAI) \\
\hline Beck Anxiety Inventory (BAI) \\
\hline
\end{tabular}

Grooved Pegboard Test

\section{DISCUSSION}

As observed in Table 2, 61 (sixty-one) instruments were used to evaluate several aspects of patients, considering batteries, subtests, scales and tasks. They can be 
ordered from the most evaluated and least contemplated: executive functions (14), global cognitive functioning (10) and mood (10), memory (9), language (5), psychiatric symptoms (3) and sensory-motor coordination (3), patients' quality of life (2) and visuoconstructive skills (2) and attention (1), perception (1) and activities of daily living (1). Early in the onset of symptoms, $24 \%$ of the patients present cognitive impairment, especially memory problems, and executive function disorders: selective attention, flexibility in reasoning and planning capacity, visuoconstructive skills and naming ability ${ }^{9}$.

What justifies the most evaluated domains in the selected articles? PD patients with mild cognitive impairment (MCI), compared with PD patients without MCI show significantly impoverished performance in almost all cognitive domains: executive functions, attention, memory, and language ${ }^{7}$. One in three patients with PD presents cognitive impairment at the time or shortly after diagnosis, progressively worsening or even causing dementia in the advanced stages ${ }^{6}$. However, cognitive alterations are common even in non-PD patients ${ }^{10}$. The cognitive impairment increases the risk of dementia, ranging from 1.7 to 5.9 and its early detection and identification of dementia risk is a major challenge due to the heterogeneity of patients' profile ${ }^{6}$. The prevalence of dementia in PD is 24 to $31 \%^{11}$, thus, evaluating the PD patient in a global and continuous way is the best path for monitoring the evolution of the effects of the disease. Comorbidity with dementia can be justified when we consider the ascending involvement of the brainstem to the cortical area. Microscopic modifications may be incorporated into its pathophysiology, including losses of neurons, gliosis and the surviving neurons may contain Lewy bodies. The loss of neurons markedly reaches the substantia nigra, though it is not restricted to it. The damage also affects the aminergic nuclei of the brainstem, Meynert's basal nucleus, hypothalamic nuclei and olfactory bulb ${ }^{12}$. For this reason, it is essential to investigate the effects of surgery such as STN-DBS on the different aspects of a subject with PD.

The MMSE was the most used instrument ${ }^{13-25}$ for the global cognitive functioning assessment among the selected studies. It was followed by MDRS ${ }^{17,24,26-31}$ and $\mathrm{RPM}^{13}, 16,18,32$. MMSE has some qualities such as fast administration, easy interpretation to be used during medical consultation; patient acceptability; cultural independence; and both language and schooling, which makes it easier to reproduce in different studies and similar performance among examiners. In 
contrast, this instrument is influenced by the application and interpretation often subjective or non-standardized by the professionals. Screening tests, such as these, known and widely used, are highly dependent on a minimal educational level and has low sensitivity and specificity ${ }^{33}$. Thus, an evaluation protocol containing only this instrument to evaluate the global cognitive functioning would have little range regarding to the patient cognitive loss.

Several instruments assessed patients EF with PD and STN-DBS, but the most recurrent were verbal fluency tasks, both semantic and phonemic 13, 14, 16-18, 20, 21, 23, 26, 27, 29, 30, 32, 34, 35, 37, 38, followed by $\mathrm{WCST}^{13-16,18,23,30,32,34}$. These tasks, in particular, presented different adaptations in each article. Evaluating EFs is a great challenge, as well as defining this concept. In general, it is understood as abilities that involve planning, organization, flexibility, monitoring and inhibitory $\operatorname{control}^{39}$, presenting an adaptive value for the subject, since their performance in activities related to personal, professional and other domains also become impaired $^{40}$. Executive dysfunction is not always associated with memory, language, visuospatial skills impairment, among others, but rather a functional decline that can often be assessed from the self-report or from a caregiver and / or family member. In patients with PD, it is a predictor of impairment, leading to ADL deficits ${ }^{8}$.

A few studies $14,16-18,21,23,27,29,32,34,35,36,41$ used 9 different types of tests to evaluate the memory and the most used ones were RAVLT (memory and verbal learning) and CBTT (memory and visual learning). The neocortex and the striatum are structures involved in implicit memory processing and dopamine is the neurotransmitter involved in the formation of these memories ${ }^{2,42}$. Therefore, with the dopaminergic deficit and the degeneration of the nuclei of the base in the PD pathology, this processing and the pre-activation of the priming and learning procedures are impaired. In the early stages of PD, there are deficits in the implicit learning of new tasks. Implicit learning is the process through which we become sensitive to certain regularities in the environment, in the absence of the intention to learn about these same regularities and in such a way that the resulting knowledge is difficult to express. In other words, implicit learning refers to the incidental or casual, and sometimes seemingly small, acquisition of a given event. It can generate significant future consequences ${ }^{42}$. 
Few articles were used to assess Language ${ }^{14,35,37}$, Attention ${ }^{23}$, Perception ${ }^{35}$ and Visuospatial Skills ${ }^{27,36}$. A study ${ }^{43}$ showed patients with PD without dementia which exhibited impairment in verbal comprehension, grammatically complex sentences identification, repetitive speech, decreased abstraction capacity, slow processing speed and attention deficit ${ }^{44}$. There is a greater impairment in naming ability and verbal fluency ${ }^{8}$. Language difficulties may be related to EF that play an important role in language. We also found difficulties in understanding grammatically complex sentences, disorders involving communication and repetitive speech ${ }^{44}$. Attention is impaired in PD, causing reduction of latency in the simple and choice reaction time. After dopaminergic replacement, there is an improvement in the identification of stimuli ${ }^{40}$. Regarding Visuospatial and Perception skills, they require the involvement of certain subcortical structures, in addition to the occipital, parietal and frontal lobes ${ }^{45}$. Deficits in this function in PD correlate with postural instability and gait difficulty ${ }^{44}$. Sensory-motor coordination also had only 2 instruments for its evaluation ${ }^{14,20}$.

Only 3 articles $^{20,31,38}$ used instruments to assess psychiatric symptoms in PD (PANDA, BPRS and Visual Analogue Mood Scale). Some authors ${ }^{46}$ investigated the existence of some information on various psychiatric conditions in patients with PD and found that more than 50\% of non-motor symptoms are not identified in clinical practice. They observed the prevalence in depression (2\% - 31\%), psychosis $(15 \%-75 \%)$, anxiety $(19 \%-67 \%)$, sleep disorder $(15 \%-87 \%)$ and cognitive deficits (MCI 18\% - 55\% and dementia reaching 31\%), among others. Psychiatric symptoms were associated with the stage of PD and cognitive impairment of the patient, but not with age, duration of illness, levodopa dose or 'ON' or 'OFF' stage. Although common, psychiatric changes in PD are not criteria for clinical diagnosis ${ }^{47}$. They may become more disabling than the motor and may be a consequence of complications of the pharmacological treatment for the motor symptoms of the disease or as an integral part of the PD clinical manifestations ${ }^{48}$.

Only 2 scales were used for PD Quality of Life (QoL): PDQ-39 $9^{49}$ and PDQL ${ }^{50}$. Regarding mood, several scales were used, having an inventory for depression appeared more often ${ }^{14,20,21,23,25,27,32,36,37}$. Together with the QoL scales, these instruments enable a more in-depth look at the individual and the impacts of the disease on his life. 
Some of the limitations of the study were the instruments used in different moments of the research, being in the inclusion and/or exclusion criteria and in the pre and postoperative evaluation of the patients. We can observe that, besides the great diversity of instruments, other aspects such as version, validation and cut points were heterogeneous as well.

As shown in Table 3, these are the instruments used before and after DBS implantation to assess the cognitive aspects of the patients. In a generic way, we could consider them as a possible battery to evaluate the effects of surgery. The literature has shown that most of the authors consider these instruments as sufficient to identify the patient's diagnostic profile. These aspects are extremely relevant to analyze the results of a study. Differences in each of them may engender results that differ from those expected. These changes range from severely compromised to slightly compromised. Another example is the use of tailored tasks, Verbal Fluency Tasks ${ }^{13}$, 14, 16-18, 20, 21, 23, 26, 27, 29, 30, 32, 34-36, 38 n-back task and dual task $^{51}$ rather than standardized tests, such as Weschler Adult Intelligence Scale ${ }^{27,35}$ and Hooper Visual Organization Test ${ }^{36}$.

The results of this review point to the absence of a specific assessment protocol for PD with STN-DBS, they display an extensive variability of instruments used in different studies. However, after analyzing each of the methodologies, we may get to a possible battery to investigate the effects of surgery from the frequency of certain instruments in the studies. The feasibility of using this battery and its findings is a suggestion for future studies that perhaps establish a standard of assessment.

Authors contributions. Eduarda Naidel Barboza e Barbosa: study concept and design, literature search, drafting and revising the manuscript; Helenice Charchat Fichman: contribution during the writing process with suggestions and corrections. 


\section{REFERENCES}

1. Pavão R. Aprendizagem Implícita e Doença de Parkinson. Dissertação de mestrado - Instituto de Biociências da Universidade de São Paulo. Departamento de Fisiologia, 2007.

2. de Paixão AO, de Jesus AVF, Silva FS, Messias GMS, Nunes TLGM, Nunes TLGM, Santos TB, Gomes MZ, Correia MGS. Doença de Parkinson: Uma Desordem Neurodegenerativa. Cadernos de Graduação - Ciências Biológicas e da Saúde. 2016; 1(16): 57-65.

3. Machado FA, Reppold CT. The effect of deep brain stimulation on motor and cognitive symptoms of Parkinson's disease - A literature review. Dementia and Neuropsychology. 2015; 9(1): 24-31, doi: 10.1590/S198057642015DN91000005.

4. Werneck ALS. Doença de Parkinson: Etiopatogenia, Clínica e Terapêutica. Revista Hospital Universitário Pedro Ernesto, 2010; 9: 10-19.

5. Heluani, AS. Cognição, humor e atividades funcionais em pacientes com doença de Parkinson submetidos à estimulação cerebral profunda bilateral em núcleo subtalâmico. Dissertação de mestrado - Faculdade de Medicina da Universidade de São Paulo, 2014.

6. Nombela C, Rowe JB, Winder-Rhodes SE, Hampshire A, Owen AM, Breen DP, Duncan GW, Khoo TK, Yarnall AJ, Firbank MJ, Chinnery PF, Robbins TW, O`Brien JT, Burn DJ, Baker RA. Genetic impact on cognition and brain function in newly diagnosed Parkinson's disease: ICICLE-PD study. Brain. 2016; 137: 2625-2631, doi: 10.1093/brain/awu201.

7. Ding W, Ding LJ, Li FF, Han Y, Mu L. Neurodegeneration and cognition in Parkinson's disease: a review. European Review for Medical and Pharmacological Sciences. 2015; 19: 2275-2281.

8. Aguilar OM, Soto CA, Esguerra M. Cambios neuropsicológicos asociados a estimulación cerebral profunda en enfermedad de parkinson: revisión teórica. Suma Psicológica. 2011; 18(2): 89-98, ISSN 0121-4381. ISSN-E 2145-9797.

9. Stella F, Gobbi LTB, Gobbi S, Oliani MM, Tanaka K, Pieruccini-Faria F. Early impairment of cognitive functions in Parkinson's disease. Arquivos de NeuroPsiquiatria. 2007; 65(2b): 406-410. https://dx.doi.org/10.1590/S0004282X2007000300008.

10.Schneider JS, Sendek S, Yang C. Relationship between Motor Symptoms, Cognition, and Demographic Characteristics in Treated Mild/Moderate Parkinson's Disease. PLoS One. 2015; 10(4): 1-11. 
11. de Oliveira MD, Machado DMS. Cognitive decline in Parkinson's disease: contributions of Neuropsychology. Revista de Medicina de Minas Gerais. 2015; 24(3): 349-354. DOI: 10.5935/2238-3182.20140103.

12. Lang AE, Lozano AM. Parkinson's disease. First of two parts. New England Journal of Medicine. 1998; 339(15): 1044-1053, DOI: 10.1056/NEJM199810083391506.

13. Cilia R, Siri C, Marotta G, Gaspari D, Landi A, Mariani CB, Benti R, Isaias IU, Vergani F, Pezzoli G, Antonini A. Brain networks underlining verbal fluency decline during STN-DBS in Parkinson's disease: An ECD-SPECT study. Parkinsonism and Related Disorders. 2007; 13(5): 290-294.

14. Heo JH, Lee KM, Paek, SH, Kim, MJ, Lee, JY, Kim,JY, Cho SY, Lim YH, Kim MR, Jeong, SY, Jeon, BS. The effects of bilateral Subthalamic Nucleus Deep Brain Stimulation (STN DBS) on cognition in Parkinson disease. Journal of the Neurological Sciences. 2008; 273(1): 19-24.

15. Lueken U, Schwarz M, Hertel F, Schweiger E, Wittling W. Impaired performance on the Wisconsin Card Sorting Test under left- when compared to right-sided deep brain stimulation of the subthalamic nucleus in patients with Parkinson's disease. Journal of Neurology. 2008; 255(12): 1940-1948.

16. Zangaglia R, Pacchetti C, Pasotti C, Mancini F, Servello D, Sinforiani E, Cristina S, Sassi M, Nappi G. Deep brain stimulation and cognitive functions in Parkinson's disease: A three-year controlled study. Movement Disorders. 2009; 24(11): 1621-1628.

17. York MK, Wilde EA, Simpson R, Jankovic J. Relationship between neuropsychological outcome and DBS surgical trajectory and electrode location. Journal of the Neurological Sciences. 2009; 287(1): 159-171.

18. Fasano A, Romito LM, Daniele A, Piano C, Zinno M, Bentivoglio AR, Albanese A. Neuropsychological changes 1-year after subthalamic DBS in PD patients: A prospective controlled study. Brain. 2010; 133(9): 2664-2676 [Periódico revisado por pares]

19. Van Wouwe NC, Ridderinkhof KR, Van Den Wildenberg WPM, Band GPH, Abisogun A, Elias WJ, Frysinger R, Wylie SA. Deep Brain Stimulation of the Subthalamic Nucleus Improves Reward-Based Decision-Learning in Parkinson's Disease. Frontiers in Human Neuroscience. 2011; 5.

20. Israeli-Korn S, Hocherman S, Hassin-Baer S, Cohen O, Inzelberg $\mathrm{R}$. Subthalamic Nucleus Deep Brain Stimulation Does Not Improve VisuoMotor Impairment in Parkinsons Disease. PLoS One. 2013; 8(6). 
21. Kim HJ, Jeon B, Yun J, Kim Y, Yang HJ, Paek S. Initial cognitive dip after subthalamic deep brain stimulation in Parkinson disease. Journal of Neurology. 2013; 260(8): 2130-2133.

22. Asahi T, Nakamichi N, Takaiwa A, Kashiwazaki D, Koh M, Dougu N, Takashima S, Tanaka K, Kuroda S. Impact of bilateral subthalamic stimulation on motor/cognitive functions in Parkinson's disease. Neurologia medicochirurgica. 2014; 54(7): 529-536.

23. Rizzone MG, Fasano A, Daniele A, Zibetti M, Merola A, Rizzi L, Piano C, Piccininni C, Romito LM, Lopiano L, Albanese A. Long-term outcome of subthalamic nucleus DBS in Parkinson's disease: From the advanced phase towards the late stage of the disease? Parkinsonism and Related Disorders. 2014; 20(4): 376-381.

24. Markser A, Maier F, Lewis C, Dembek T, Pedrosa D, Eggers C, Timmermann L, Kalbe E, Fink G, Burghaus L. Deep brain stimulation and cognitive decline in Parkinson's disease: The predictive value of electroencephalography. Journal of Neurology. 2015; 262(10): 2275-2284.

25. Krishnan S, Prasad S, Pisharady K, Sarma G, Sarma S, Kishore A. The decade after subthalamic stimulation in advanced Parkinson's disease: A balancing act. (Original Article)(Report) Neurology India. 2016; 64(1): 81 [Periódico revisado por pares].

26. Klempírová O, Jech R, Urgosík D, Klempír J, Spacková N, Roth J, Růzicka E. Deep brain stimulation of the subthalamic nucleus and cognitive functions in Parkinson's disease. Prague Medical Report. 2007; 108(4): 315-323.

27. Witt K, Daniels C, Reiff J, Krack P, Volkmann J, Pinsker MO, Krause M, Tronnier V, Kloss M, Schnitzler A, Wojtecki L, Bötzel K, Danek A, Hilker R, Sturm V, Kupsch A, Karner E, Deuschl G. Neuropsychological and psychiatric changes after deep brainstimulation for Parkinson's disease: a randomised, multicentre study. Lancet Neurology. 2008; 7(7): 605-614 [Periódico revisado por pares]

28. Hariz M. Deep brain stimulation plus best medical therapy versus best medical therapy alone for advanced Parkinson's disease. Lancet Neurology. 2009; 8(3): 223-224 [Periódico revisado por pares]

29. Daniels C, Krack P, Volkmann J, Pinsker MO, Krause M, Tronnier V, Kloss M, Schnitzler A, Wojtecki L, Bötzel K, Danek A, Hilker R, Sturm V, Kupsch A, Karner E, Deuschl G, Witt K. Risk factors for executive dysfunction after subthalamic nucleus stimulation in Parkinson's disease. Movement Disorders. 2010; 25(11): 1583-1589. 
30. Houvenaghel JF, Jeune F, Dondaine T, Esquevin A, Robert G, Péron J, Haegelen C, Drapier S, Jannin P, Lozachmeur C, Argaud S, Duprez J, Drapier D, Vérin M, Sauleau P. Reduced Verbal Fluency following Subthalamic Deep Brain Stimulation: A Frontal-Related Cognitive Deficit? PLoS One. 2015; 10(10).

31. Pham UHG, Andersson S, Toft M, Pripp AH, Konglund AE, Dietrichs E, Malt UF, Skogseid IM, Haraldsen IRH, Solbakk AK. Self-Reported Executive Functioning in Everyday Life in Parkinson's Disease after Three Months of Subthalamic Deep Brain Stimulation. Parkinson's Disease. 2015; 461453.

32. Castelli L, Lanotte M, Zibetti M, Caglio M, Rizzi L, Ducati A, Bergamasco B, Piano L. Apathy and verbal fluency in STN-stimulated PD patients. Journal of Neurology. 2007; 254(9): 1238-1243.

33. Barbosa ENB, Charchat-Fichman H. (Advisor). Neuropsychological assessment contribuition to Mild Cognitive Impairment (MCI): methodological issues. Rio de Janeiro, 2015. 144p. MSc. Dissertation - Psychological Departament, Pontifícia Universidade Católica do Rio de Janeiro.

34. Castelli L, Rizzi L, Zibetti M, Angrisano S, Lanotte M, Lopiano L. Motor and cognitive outcome in patients with Parkinson's disease 8 years after subthalamic implants. Parkinsonism and Related Disorders. 2010; 16(2): 115118.

35. Yágüez L, Costello A, Moriarty J, Hulse N, Selway R, Clough C, Samuel M, Ashkan K. Cognitive predictors of cognitive change following bilateral subthalamic nucleus deep brain stimulation in Parkinson's disease. Journal of Clinical Neuroscience. 2014; 21(3): 445-450.

36. Tang V, Zhu C, Chan D, Lau C, Chan A, Mok V, Yeung J, Poon W. Evidence of improved immediate verbal memory and diminished category fluency following STN-DBS in Chinese-Cantonese patients with idiopathic Parkinson's disease. Neurological Sciences. 2015; 36(8): 1371-1377.

37. Tremblay C, Macoir J, Langlois M, Cantin L, Prudhomme M, Monetta L. The effects of subthalamic deep brain stimulation on metaphor comprehension and language abilities in Parkinson's disease. Brain and Language. 2015; 141: 103109. [Periódico revisado por pares]

38. Vonberg I, Ehlen F, Fromm O, Kühn A, Klostermann F. Deep Brain Stimulation of the Subthalamic Nucleus Improves Lexical Switching in Parkinsons Disease Patients. PLoS One. 2016; 11(8).

39. Lourenço RA, Veras RP, Ribeiro PCC. Confiabilidade teste-reteste do miniexame do estado mental em uma população idosa assistida em uma unidade 
ambulatorial de saúde. Revista Brasileira de Geriatria e Gerontologia. 2008; 11: 7-16.

40. Macuglia GR, Rieder CRM, de Almeida RMM. Funções executivas na doença de Parkinson: Revisão da Literatura. PSICO. 2012; 43(4): 552-561.

41. Ventre-Dominey J, Mollion H, Thobois S, Broussolle E. Distinct effects of dopamine vs STN stimulation therapies in associative learning and retention in Parkinson disease. Behavioral Brain Research. 2016; 302: 131-141. [Periódico revisado por pares]

42. Rita, HJP; Reis, AI. (Advisor) Dissociação da memória explícita e implícita da Doença de Parkinson. 2012. 56p. MSc. Dissertation - Human Sciences and Social College. Universidade do Algarve.

43. Poliakoff E, Smith-Spark JH. Everyday cognitive failures and memory problems in Parkinson's patients without dementia. Brain Cognition. 2008; 67(3): 340-350. doi: 10.1016/j.bandc.2008.02.004.

44. Melo LM, Barbosa ER, Caramelli P. Declínio cognitivo e demência associados à doença de Parkinson: características clínicas e tratamento. Revista de Psiquiatria Clínica. 2007; 34(4): 176-183. ISSN 0101-6083.

45. Galhardo MMAMC, do Amaral AKFJ, Vieira ACC. Caracterização dos distúrbios cognitivos na Doença de Parkinson. Revista CEFAC. 2009; 11(2): 251-257.

46. Grover S, Somaiya M, Kumar S, Avasthi A. Psychiatric aspects of Parkinson's disease. Journal of Neuroscience Rural Practice. 2015; 6(1): 65-76. doi: 10.4103/0976-3147.143197.

47. Aarsland D, Larsen JP, Lim NG, Janvin C, Karlsen K, Tandberg E, Cummings JL. Range of neuropsychiatric disturbances in patiens with Parkinson's disease. Journal of Neurology, Neurosurgery and Pshychiatry. 2009; 67: 492-496.

48. Junior AS, Cabral ACJ. Alterações Psiquiátricas na Doença de Parkinson. In Forlenza, OV; Caramelli, P. Neuropsiquiatria geriátrica. São Paulo: Editora Atheneu, 2000.

49. Chrischilles EA, Rubenstein LM, Voelker MD, Wallace RB, Rodnitzky RL. Linking clinical variables to health-related quality of life in Parkinson's disease. Parkinsonism Related Disorders. 2003; 8: 199-209.

50. De Boer AGEM, Spruijt RJ, Sprangers MAG, de Haes JCJM. Disease-specific quality of life: is it one construct? Quality of Life Research, Oxford. 1998; 7: 135-142. 
51. Alberts JL, Voelcker-Rehage C, Hallahan K, Vitek M, Bamzai R, Vitek JL. Bilateral subthalamic stimulation impairs cognitive-motor performance in Parkinson's disease patients. Brain. 2008; 131(12): 3348-3360. 
\begin{tabular}{|l|}
\hline ARTICLE 2 \\
Barbosa E.N.B., Charchat-Fichman H. How Is Cognition on Subthalamic Nucleus \\
Deep Brain Stimulation Parkinson's Disease Patients? A 2007 to 2017 Systematic \\
Review. Dementia and Neuropsychologia, 2019, v. 13, n. 4, p. 367-377.
\end{tabular}

\begin{abstract}
Introduction: The impairments in cognitive functions such as memory, executive function, visuospatial skills and language in Parkinson's Disease (PD) are increasingly drawing attention in current literature. Studies investigaying the relationship between deep brain stimulation of the subthalamic nucleus (ECPNST) and cognitive functioning are contradictory. Objective: This systematic review aims to analyze the impact on the cognitive functioning of patients with PD and NPS-STD. Method: The articles were collected in the Medline / PubMed databases published in the 2007-2017 period, using PRISMA criteria. Results: After analyzing 27 articles, many opposite results were observed. Conclusion: It was not possible to agree on a cognitive functioning standard, which makes it difficult to establish a neuropsychological profile for patients with this disease who underwent surgery, so further studies are needed.
\end{abstract}

Keywords: Parkinson Disease, Deep Brain Stimulation, Cognitive Functions, Cognition 


\section{How Is Cognition on Subthalamic Nucleus Deep Brain Stimulation Parkinson's Disease Patients? A 2007 to 2017 Systematic Review.}

\section{INTRODUCTION}

The diagnosis of PD is performed through clinical criteria by trained professionals such as neurologists. These criteria are based on the identification of clinical manifestations, pure motor symptoms. Patients with PD present, in addition to motor impairments, non-motor impairments, as a variety of neuropsychiatric symptoms ${ }^{1,2}$ changes in sleep, behavior and $\operatorname{cognition}^{3,4}$, which may lead to dementia $^{5,6}$.

The impairments in cognitive functions such as memory, executive function, visuospatial skills and language in PD are increasingly drawing attention in current literature ${ }^{6}$. One in three patients with PD presents cognitive impairment at the time or soon after diagnosis, progressively worsening or even causing dementia in the later stages ${ }^{7}$.

Since 1940, surgical treatment of PD has been performed and, since 1998, ablation has given rise to deep brain stimulation (ECP), targeting the subthalamic nucleus $(\mathrm{STN})$ or globuspalildus $(\mathrm{GPi})^{5,8}$. The most chosen target by the centers that perform the surgery is in the STN due to the possibility of decreasing the doses of the drugs and, consequently, reducing the adverse effects.

The literature points to evident motor and QoL improvement after DBS in patients with PD, however, studies dedicated to investigating the relationship between STN-DBS and cognitive functioning are controversial, and further studies are needed to investigate this relationship.

In this context, the investigation of the cognitive effects of STN-DBS in PD becomes fundamental. The objective of this study is to analyze the effects of subthalamic nucleus (STN) DBS on cognition of PD patients through a systematic review. The Preferred Reporting Items for Systematic Review and Meta-Analyzes (PRISMA) Checklist was employed. 


\section{METHODOLOGY}

The systematic review is a type of scientific research that aims to gather, critically evaluate and conduct a synthesis of multiple primary studies ${ }^{10}$.

Bibliographic Survey We projected a systematic review of the literature according to the Preferred Reporting Items for Systematic Review and Meta-Analyzes (PRISMA) criteria. The following terms were used: "Deep Brain Stimulation", "DBS", "Cognitive Functions" and "Parkinson Disease" with the Boolean operator "and". We selected scientific papers published in English between January 2007 and January 2017, with comparative clinical trials in humans, in Medline/PubMed databases. Articles published before 2007, systematic reviews, case studies, books chapters and studies using animals were excluded.

Studies selection Initially, this method identified 345 responses (Figure 1). To refine the research, the following topics were selected: "Parkinson's Disease", "Subthalamic Nuclei", "Deep Brain Stimulation", "DBS", "Cognition" (263), published in the Medline/PubMed database (223) between 2007 and 2017 (195). From this, a title and summary analysis was performed manually to consider only the work with human clinical trials (66). Literature reviews and case studies were excluded, as well as articles containing problems in the methodology, such as not inclusion of (a) inclusion and exclusion criteria, (b) complete assessment protocol and (c) lack of pre or post-surgery assessment fulfillment (27). The researchers selected the articles independently: they considered suitable studies that (a) evaluated PD patients cognition with STN-DBS; (b) presented the instruments and domains evaluated; and (c) presented pre and post-surgical results. of articles was carried out independently by the researchers.

Figure 1. Articles research fluxogram.

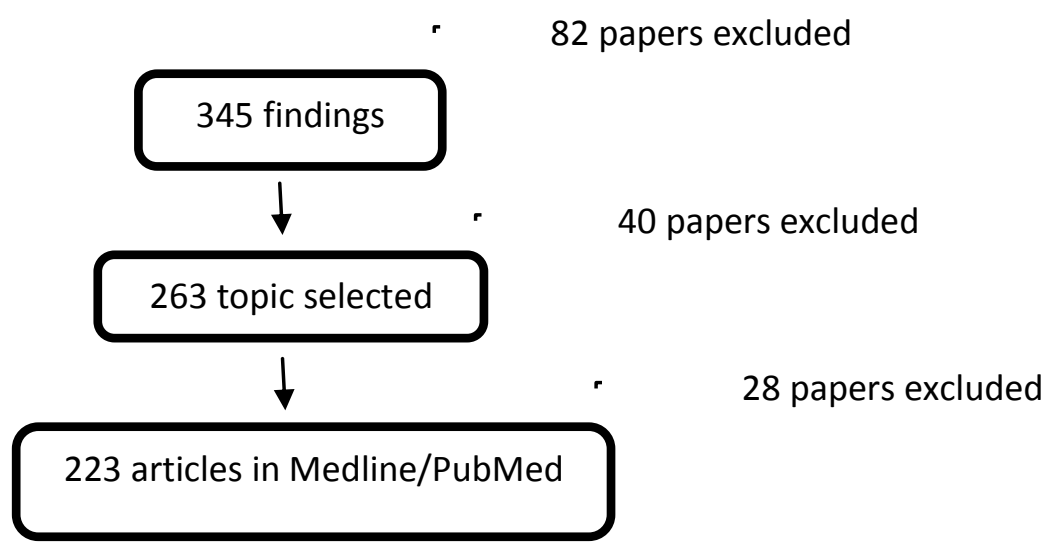


195 articles between 2007 and 2017

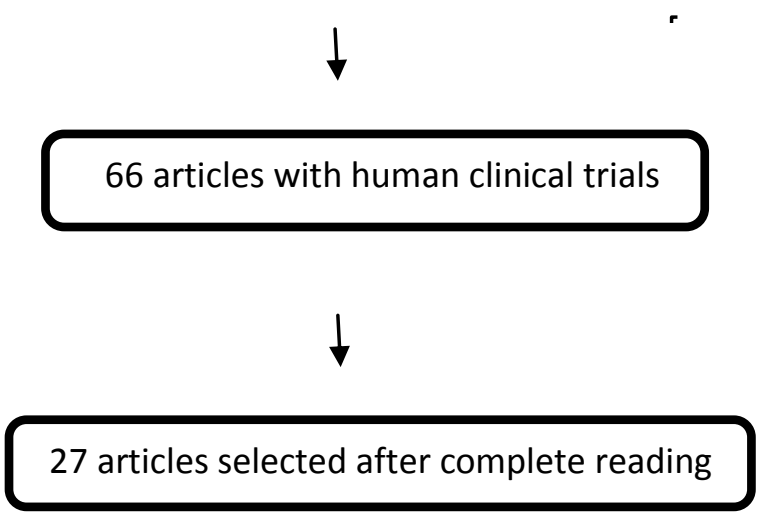

39 papers excluded

27 articles selected after complete reading

\section{RESULTS}

Following are the final list of articles that were included by the research criteria in ascending order of year, with objectives and results (Table 1) and a list of studies grouped according to the effects of DBS on specific cognitive domains with neuropsychological tasks (carried out in each of the studies taken into account) (Table 2).

There were 27 studies with a total of 832 patients with STN-DBS and 458 patients with DP and / or healthy subjects in the control group who did not undergo surgery. The age ranged from 51 to 67 years, the disease duration ranged between 9.7 and 15.75 years, schooling (when mentioned) ranged between 1.9 and 14.5 years and the pre-surgical evaluation occurred 2 weeks before surgery and postoperative up to 132 months (11 years). 
Table 1. List of articles included in the systematic review criteria.

\begin{tabular}{|c|c|c|c|c|}
\hline & Name & Year & Objective & Result \\
\hline 1 & $\begin{array}{l}\text { Cilia et al. Brain networks underlining } \\
\text { verbal fluency decline during STN-DBS in } \\
\text { Parkinson's disease: An ECD-SPECT study. }\end{array}$ & 2007 & $\begin{array}{l}\text { To evaluate changes of evaluation after a DBS- } \\
\text { STN and its possible correlation with the } \\
\text { cognitive result related to the frontal lobe. }\end{array}$ & $\begin{array}{l}\text { Patients with STN-DBS improved motor symptoms and reduced } \\
\text { medications, but they selectively decreased the fluency of the } \\
\text { categories. }\end{array}$ \\
\hline 2 & $\begin{array}{l}\text { Klempírová et al. Deep brain stimulation of } \\
\text { the subthalamic nucleus and cognitive } \\
\text { functions in Parkinson's disease. }\end{array}$ & 2007 & $\begin{array}{l}\text { To evaluate how STN-DBS affects cognitive } \\
\text { functions. }\end{array}$ & $\begin{array}{l}\text { Patients treated by STN-DBS tend to worsen executive functions } \\
\text { and logical memory. }\end{array}$ \\
\hline 3 & $\begin{array}{l}\text { Castelli et al. Apathy and verbal fluency in } \\
\text { STN-stimulated PD patients. }\end{array}$ & 2007 & $\begin{array}{l}\text { To evaluate apathy and its relationship with } \\
\text { verbal fluency tasks in patients with PD who } \\
\text { underwent STN-DBS. }\end{array}$ & $\begin{array}{l}\text { The results suggest that STN-DBS does not necessarily induce } \\
\text { apathy, even if individual patients show moderate postoperative } \\
\text { worsening of apathetic symptoms. }\end{array}$ \\
\hline 4 & 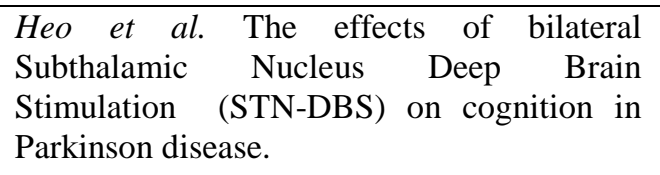 & 2008 & $\begin{array}{l}\text { Research the STN-DBS effects on cognition and } \\
\text { mood. }\end{array}$ & $\begin{array}{l}\text { Bilateral STN-DBS did not lead to a significant overall } \\
\text { deterioration in cognitive function. However, it has small, long- } \\
\text { term detrimental impacts on the memory and function of the } \\
\text { frontal lobe. }\end{array}$ \\
\hline 5 & $\begin{array}{l}\text { Witt et al. Neuropsychological and } \\
\text { psychiatric changes after deep brain } \\
\text { stimulation for Parkinson's disease: a } \\
\text { randomized, multicenter study. }\end{array}$ & 2008 & $\begin{array}{l}\text { To evaluate the DBS neuropsychiatric } \\
\text { consequences in patients with PD. }\end{array}$ & $\begin{array}{l}\text { STN-DBS does not reduce cognition or general affectivity, } \\
\text { although there is a selective decrease in frontal cognitive } \\
\text { functions and an improvement in anxiety in patients after } \\
\text { treatment, but not influencing improvements in quality of life. }\end{array}$ \\
\hline 6 & $\begin{array}{l}\text { Alberts et al. Bilateral subthalamic } \\
\text { stimulation impairs cognitive-motor } \\
\text { performance in Parkinson's disease patients. }\end{array}$ & 2008 & $\begin{array}{l}\text { To determine the effects of unilateral and } \\
\text { bilateral STN-DBS on upper extremity motor } \\
\text { function and cognitive performance in single } \\
\text { and double task conditions in patients with } \\
\text { advanced PD. }\end{array}$ & $\begin{array}{l}\text { Significant decreases in cognitive and motor function in modest } \\
\text { dual-task conditions with bilateral STN-DBS, but not unilateral. }\end{array}$ \\
\hline
\end{tabular}


$7 \quad$ Lueken et al. Impaired performance on the Wisconsin Card Sorting Test under left when compared to right-sided deep brain stimulation of the subthalamic nucleus in patients with Parkinson's disease.
2008 To evaluate whether changes in performance of executive tasks after chronic ECP may be predominantly associated with stimulation of only one hemisphere.
STN-DBS is not only involved in motor control, but also participates in functions of the cognitive domain. All patients had a significant improvement in postoperative motor symptoms. Selected aspects of executive task performance were compromised under the left - when compared to right side pacing.
8 Zangaglia et al. Deep brain stimulation and cognitive functions in Parkinson's disease: A three-year controlled study neuropsychological outcome and DBS surgical trajectory and electrode location

10 Williams et al. Deep brain stimulation plus best medical therapy versus best medical therapy alone for advanced Parkinson's disease.

11 Daniels et al. Risk factors for executive dysfunction after subthalamic nucleus stimulation in Parkinson's disease

201
Verbal fluency worsening after DBS, but relatively safe surgery
from the cognitive point of view, since the short-term worsening of the front-executive functions was transient
2009 Evaluate whether surgery and the best medical therapy have improved a self-reported quality of life better than advanced medicine.

2009 To observe if the differences in the position of the electrode and in the surgical trajectory of the ECP can lead to
neuropsychological outcome.
After 1 year, surgery and improved medical therapy improved patient self-reported quality of life, rather than the best medical therapy in patients with advanced PD - clinically significant differences.

Cognitive and emotional changes after 6 months of bilateral STNDBS may be related to the surgical trajectory and to the positioning of the electrodes.
2010 To evaluate the baseline parameters that contribute to the deterioration of cognitive functioning after DBS.

Surgical procedure, exact electrode placement or postoperative administration may be more relevant for a decline in executive functioning after STN-DBS, in addition to factors such as age, high levodopa dosages and high scores in the UPDRS III axial subset in OFF stage.

12 Castelli et al. Neuropsychological changes 1-year after subthalamic DBS in PD patients: A prospective controlled study

To investigate the neuropsychological effect advanced PD.
STN-DBS Phonemic verbal fluency decreased one year after STN-DBS, in patients with while the other cognitive domains did not change significantly. Only 4 subjects had significant cognitive decline 1 year after surgery. 
13 Fasano et al. Motor and cognitive outcome in patients with Parkinson's disease 8 years after subthalamic implants

14 Van Wouwe et al. Deep Brain Stimulation of the Subthalamic Nucleus Improves RewardBased Decision-Learning in Parkinson's Disease

15 Israeli-Korn et al. Subthalamic Nucleus Deep Brain Stimulation Does Not Improve Visuo-Motor Impairment in Parkinsons Disease

16 Kim et al. Initial cognitive dip after subthalamic deep brain stimulation in Parkinson disease

17 Yágüez et al. Cognitive predictors of cognitive change following bilateral subthalamic nucleus deep brain stimulation in Parkinson's disease

18 Asahi et al. Impact of bilateral subthalamic stimulation on motor/cognitive functions in Parkinson's disease
2010 To assess long-term PD patients undergoing STN-DBS 8 years previously: long-term motor outcome of symptoms that improve in the short and medium term with STN-DBS; identification of predictors of long-term motor outcome; an long-term cognitive and behavioral outcome.
2011 To investigate the effect of STN-DBS on reward-based learning in patients diagnosed with PD.

2013 To evaluate how STN-DBS affects visuomotor coordination in patients with PD.

2013 To examine whether the rate of change in overall cognitive functioning during the initial 6 months after STN-DBS was different from the mean change of 6 months that occurred between

6 and 36 months after surgery.

2014

Specifically establish a detailed neuropsychological profile before and after STN-DBS and identify any pre-surgical cognitive profile that can predict cognitive outcomes after stimulation.
STN-DBS is a safe procedure for cognitive and behavioral morbidity in relation to long-term follow-up. However, the overall benefit decreases later in the course of the disease due to the progression of PD and to the appearance of stimulant-resistant medications and symptoms.

The DBS cognitive effects have benefited a subset of relatively younger patients with relatively less disease duration in daily association learning situations.

Clinically measured "low-level" motor function responds to STNDBS, but cognitive and "high-level" functions related to VMC may not respond to STN-DBS.

The decline in overall cognitive function was faster in the first 6 months after surgery, compared to 6 months between 6 and 36 months post surgery.

Non-dementia patients with mild impairment, both in general intellectual functions and in list learning, may be at a greater risk of decline in other aspects of verbal memory after STN-DBS.

2014 Systemically assess the impact of bilateral STNDBS on motor and cognitive functions in patients with PD. ilateral NST-DBS can significantly improve cognitive function in a given subgroup of patients whose therapeutic effects on motor function are prominent. 
19 Rizzone et al. Long-term outcome of subthalamic nucleus DBS in Parkinson's disease: From the advanced phase towards the late stage of the disease?
2014 To report the results of a long-term follow-up of patients implanted with DBS bilaterally in two centers.

Despite the NST-DBS long-term safety and efficacy in PD, the patients functionality worsened over time, mainly for the onset and progression of levodopa and non-motor-resistant symptoms.

20 Houvenaghel et al. Reduced Verbal Fluency following Subthalamic Deep Brain Stimulation: A Frontal-Related Cognitive Deficit?

2015 Explore the mechanisms underlying DBS.

Cognitive deceleration and apathy seem to have a more decisive influence on the impairment of phonemic verbal fluency after DBS.

21 Markser et al. Deep brain stimulation and cognitive decline in Parkinson's disease: The predictive value electroencephalography

2015 To examine whether clinical recordings of EEG can be used to predict cognitive impairment in PD patients undergoing STN-DBS.

The GTE preoperative score can be used to identify patients with PD who are at high risk of developing cognitive impairment after STN-DBS surgery even though their preoperative cognitive status is normal.

22 Pham et al. Self-Reported Executive Functioning in Everyday Life in Parkinson's Disease after Three Months of Subthalamic Deep Brain Stimulation

To compare self-reported daily executive functioning in patients with PD before and after three months of NTS-DBS.

Patients with PD showed significant improvement in executive functioning of daily life 3 months after surgery, anxiety indexes decreased significantly and psychiatric symptoms, including apathy, remained unchanged. Only the preoperative depressive mood presented predictive value for the improvement of the executive function and seems to prevent potentially favorable results of the NST-DBS in some aspects of the executive function.

23 Tang et al. Evidence of improved immediate verbal memory and diminished category fluency following STN-DBS in ChineseCantonese patients with idiopathic

2015 To investigate the neuropsychological effects Cantonese patients with PD.

STN-DBS A diminished performance of verbal fluency was observed, on the other hand, an improvement of the immediate verbal memory, besides anxiety level

Parkinson's disease

24 Tremblay et al. The effects of subthalamic deep brain stimulation on metaphor comprehension and language abilities in Parkinson's disease

To determine the STN-DBS effects on the comprehension of metaphor and linguistic abilities such as lexical and semantic abilities.
STN-DBS had a significant beneficial effect on motor symptoms in PD, but such stimulation had no effect on the understanding of the metaphor or any other cognitive ability assessed in this study. 
25 Krishnan et al. The decade after subthalamic stimulation in advanced Parkinson's disease: A balancing act. Improves Lexical Switching in Parkinson's Disease Patients. Parkinson disease.
2016 To we examined the long-term quality of life, motor and cognitive outcomes of bilateral subthalamic nucleus STN DBS and the pre-DBS factors that predict sustained motor benefits at or beyond 7 years from surgery.

\section{Outline the nature of verbal fluency} dysfunction.

27 Ventre-Dominey et al. Distinct effects of dopamine vs STN stimulation therapies in associative learning and retention in

2016 To investigate and to compare the results of the treatment with dopamine versus DBS in the capacity of the patient with PD to acquire and to maintain over the successive days their performance in the visual work memory.
Improvements in severity of motor fluctuations, stiffness, and tremor are the long-lasting STN-DBS benefits, which can last for a decade. However, these are compensated by the higher evodopa requirement, worsening of cognitive and axial functions, such as bradykinesia and dyskinesias.

The STN-DBS group tasks performance was lower than that of healthy controls. In addition to affecting motor symptoms, surgery seems to influence the dynamics of cognitive procedures.

While STN-DBS patients demonstrate more accurate and faster responses in the ON stage than in the OFF stage, regardless of the day of the test, patients with dopamine replacement therapy had a more accurate and faster ON response compared to OFF during the first day of learning and then maintained or even improved their performance on the second day after consolidation in both the OFF and $\mathrm{ON}$ stages. 
Table 2. Domains evaluated and effects found in each article.

\begin{tabular}{|c|c|c|}
\hline Domain & STN DBS cognitive effects & Articles by \\
\hline $\begin{array}{l}\text { Global Cognitive } \\
\text { Functioning / Reasoning }\end{array}$ & $\begin{array}{l}\uparrow(\text { MMSE) } \\
\uparrow(\text { DemTect) } \\
\uparrow \text { Addenbrooke } \\
=(\text { MDRS) } \\
=(\text { MMSE) } \\
=\text { (Repeatable Battery For The Assessment of Neuropsychological Status) } \\
=\text { (Wechsler Adult Inteligence Scale) } \\
=(\text { Japanese Adult Reading Test) } \\
=\text { abstract reasoning (Raven Colour Matrices) } \\
=(\text { MoCA*) } \\
\downarrow \text { MMSE } \\
\downarrow \text { MDRS } \\
\downarrow \text { Raven }\end{array}$ & $\begin{array}{l}\text { Lueken et al, 2008; Wouwe et al, } 2011 \\
\text { Markser et al, 2015 } \\
\text { Krishnan et al, 2016 } \\
\text { Klempírova et al, 2007; Witt et al, 2008; } \\
\text { Daniels et al, 2010 } \\
\text { Cilia et al, 2007; Heo et al, 2008; } \\
\text { Zanglagia et al, 2009; Israeli-Korn et al, } \\
\text { 2013; Asahi et al, 2014 } \\
\text { Asahi et al, 2014 } \\
\text { Asahi et al, 2014 } \\
\text { Asahi et al, 2014 } \\
\text { Castelli et al, 2007; Castelli et al, 2010; } \\
\text { Rizzone et al, 2014 } \\
\text { Tang et al, 2015; Tremblay et al, 2015 } \\
\text { York et al, 2009; Kim et al, 2013; } \\
\text { Markser et al, 2015; Krishnan et al, 2016 } \\
\text { Williams et al, 2010; York et al, 2009; } \\
\text { Markser et al, 2015 } \\
\text { Fasano et al, 2010 }\end{array}$ \\
\hline
\end{tabular}




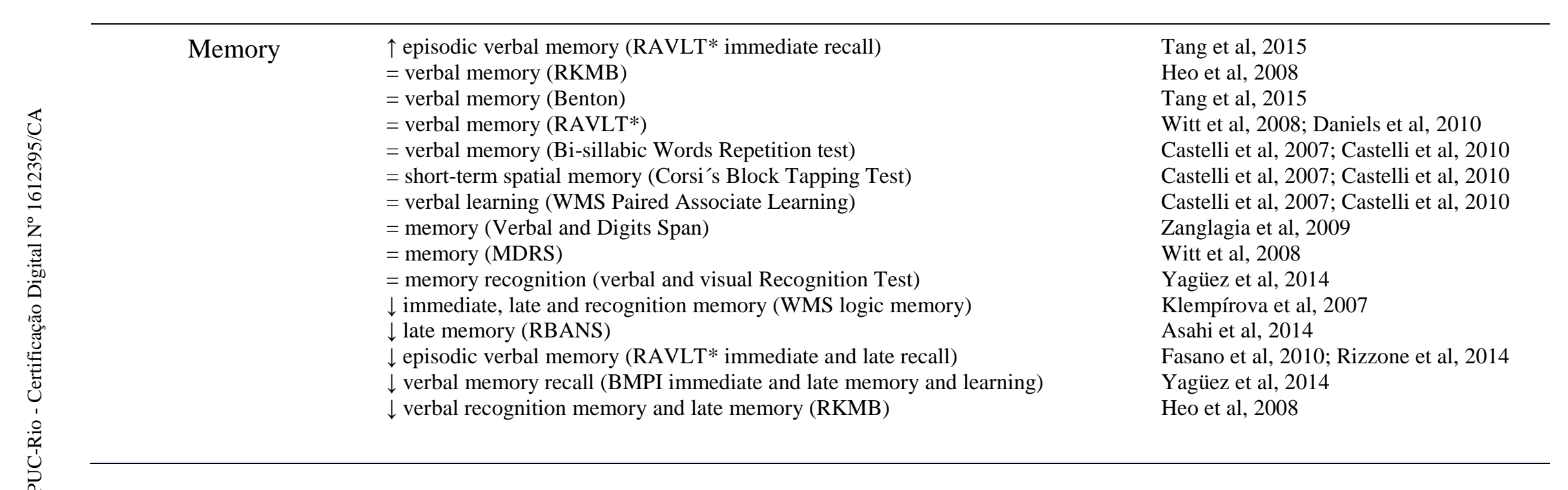




\begin{tabular}{|c|c|c|}
\hline Executive Functions & $\begin{array}{l}\uparrow \text { (WCST right categories, right answers, errors } n^{\circ} \text { and non perseveratives errors) } \\
\uparrow \text { (Stroop effect) } \\
\uparrow \text { executive functioning (BRIEF-A) } \\
\uparrow \text { visuoespacial working memory (working memory tasks) } \\
\uparrow \text { stimulus-action-reward association (Haruno and Kawato task) } \\
=\text { regulation behavior (BRIEF-A) } \\
=\text { semantic verbal fluency (tasks) } \\
=\text { fonemic verbal fluency (tasks) } \\
=\text { cognitive flexibility (alternate verbal fluency tasks) } \\
=\text { cognitive flexibility (Trail Test B) } \\
=\text { abstracts concepts development and cognitive flexibility (WCST*) } \\
=\text { abstracts concepts development (metaphor comprehension) } \\
=\text { response initiation and response inhibition (Hayling Sentence Completion Test) } \\
=\text { working memory (Span Dígitos) } \\
=\text { (Stroop effect) } \\
=\text { executive functions (Frontal Assessment Battery) } \\
=\text { processing of outcome errors (Haruno e Kawato task) } \\
=\text { working memory (n-back DBS STN unilateral task) } \\
\downarrow \text { logic executive functions (WCST* e Raven) } \\
\downarrow \text { semantic verbal fluency (category task) } \\
\end{array}$ & $\begin{array}{l}\text { Lueken et al, } 2008 \\
\text { Houvenaghel et al, } 2015 \\
\text { Pham et al, 2015 } \\
\text { Ventre-Dominey et al, } 2016 \\
\text { Wouwe et al, 2011 } \\
\text { Pham et al, 2015 } \\
\text { Castelli et al, 2007; Castelli et al, 2010; } \\
\text { Tremblay et al, 2015 } \\
\text { Cilia et al, 2007 } \\
\text { Tremblay et al, 2015 } \\
\text { Castelli et al, 2007 } \\
\text { Cilia et al, 2007; Castelli et al, 2007; } \\
\text { Castelli et al, 2010; Houvenaghel et al, } \\
2015 \\
\text { Tremblay et al, 2015 } \\
\text { Yagüez et al, 2014 } \\
\text { Daniels et al, 2010; Tang et al, 2015 } \\
\text { Tang et al, 2015 } \\
\text { Israeli-Korn et al, 2013 } \\
\text { Wouwe et al, 2011 } \\
\text { Alberts et al, 2008 } \\
\text { Zanglagia et al, 2009 } \\
\text { Cilia et al, 2007; Witt et al, 2008; York et } \\
\text { al, 2009; Daniels et al, 2010; } \\
\text { Houvenaghel et al, 2015; Tang et al, } \\
\text { 2015; Vonberg et al, 2016 } \\
\text { Castelli et al, 2007; Klempírova et al, } \\
\text { 2007; Witt et al, 2008; Zanglagia et al, } \\
\text { 2009; York et al, 2009; Daniels et al, } \\
\text { 2010; Castelli et al, 2010; Fasano et al, } \\
\text { 2010; Kim et al, 2013; Yagüez et al, } \\
\text { 2014; Houvenaghel et al, 2015; Vonberg }\end{array}$ \\
\hline
\end{tabular}




\author{
$\downarrow$ (Stroop effect) \\ $\downarrow$ interference (Trail Test B form) \\ $\downarrow$ planning skills (London Tower) \\ $\downarrow$ working memory (n-back DBS STN bilateral tasks)
}

et al, 2016

Williams et al, 2010

Witt et al, 2008

Witt et al, 2008

Heo et al, 2008; Lueken et al, 2008;

Fasano et al, 2010; Rizzone et al, 2014

Klempírova et al, 2007; Heo et al, 2008;

Kim et al, 2013

Klempírova et al, 2007; Kim et al, 2013; Rizzone et al, 2014; Houvenaghel et al, 2015

Klempírova et al, 2007

Alberts et al, 2008 


\begin{tabular}{|c|c|c|}
\hline Attention & $\begin{array}{l}=(\text { Trail Test } \mathrm{A} \text { and } \mathrm{B} \text { forms }) \\
=(\text { Stroop }) \\
=(\text { MDRS attention }) \\
=\left(\text { WCST }^{*}\right) \\
=(\text { Span Digits }) \\
\downarrow(\text { WCST } *) \\
\downarrow(\text { RBANS })\end{array}$ & $\begin{array}{l}\text { Heo et al, 2008; Castelli et al, 2010; } \\
\text { Houvenaghel et al, } 2015 \\
\text { Witt et al, 2008; Daniels et al, 2010; Tang } \\
\text { et al, 2015 } \\
\text { Witt et al, 2008; } \\
\text { Castelli et al, 2010 } \\
\text { Tang et al, 2015 } \\
\text { Rizzone et al, } 2014 \\
\text { Asahi et al, } 2014\end{array}$ \\
\hline Perception & $\begin{array}{l}=(\text { Visual Object and Space Perception Battery Object Decision task }) \\
=(\text { Visual Object and Space Perception Incomplete Letters task })\end{array}$ & $\begin{array}{l}\text { Yagüez et al, } 2014 \\
\text { Yagüez et al, } 2014\end{array}$ \\
\hline Language & $\begin{array}{l}\uparrow \text { lexical changing and word production } \\
=(\text { Boston Naming Test } *) \\
=(\text { Graded Naming Test }) \\
=(\text { lexical decision task and words association task) } \\
\downarrow \text { word production } \\
\downarrow \text { Vocabulary (WASI) } \\
\downarrow \text { fluency tasks (Fonemic and Semantic Verbal Fluency Test) }\end{array}$ & $\begin{array}{l}\text { Vonberg et al, } 2016 \\
\text { Heo et al, 2008; Tang et al, } 2015 \\
\text { Yagüez et al, } 2014 \\
\text { Tremblay et al, } 2015 \\
\text { Cilia et al, 2007 } \\
\text { Williams et al, } 2010 \\
\text { Rizzone et al, } 2014\end{array}$ \\
\hline $\begin{array}{l}\text { Visuoconstructive and } \\
\text { visuospacial skills }\end{array}$ & $\begin{array}{l}=(\text { MDRS }) \\
=\text { visuoespacial reasoning (Raven) } \\
=(\text { Benton }) \\
=\text { visuospacial organization capacity (Hooper Test) } \\
\downarrow \text { (Corsi's Block Tappint Test forward and backward) } \\
\downarrow \text { visuoconstructive skills (RBANS) }\end{array}$ & $\begin{array}{l}\text { Witt et al, } 2008 \\
\text { Cilia et al, } 2007 \\
\text { Witt et al, } 2008 \\
\text { Tang et al, } 2015 \\
\text { Rizzone et al, } 2014 \\
\text { Asahi et al, } 2014\end{array}$ \\
\hline
\end{tabular}




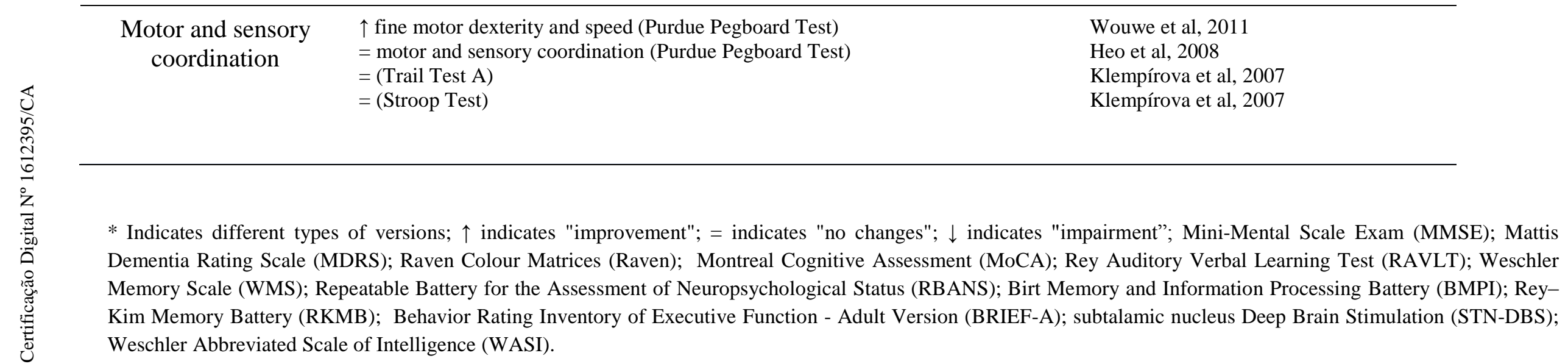


Global cognitive functioning Most studies $^{9-21}$ evaluated global cognitive functioning with 3 different instruments and did not observe a significant change in subjects performance. Only 3 articles $^{22-24}$ presented impairment in the overall cognitive functioning on their sample.

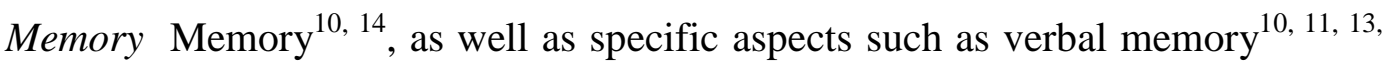
20, 17, 18 , verbal learning ${ }^{17,18}$, recognition ${ }^{27}$ and spatial memory ${ }^{17,18}$ didn't show significant difference before and after surgery. Although there was a decline in specific aspects in 6 articles $9,13,16,19,23,27$.

Executive function Several EFs aspects were evaluated: visuoespacial working memory, stimulus-action-reward association, behavior regulation, semantic and phonemic verbal fluency, cognitive flexibility, abstracts concepts development,

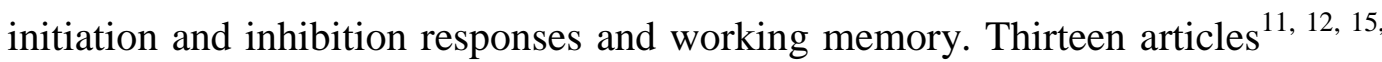
$17,18,20,21,25-30$ presented stability or improvement in their result. However, the most part of articles ${ }^{9-14}, 17-19,22-25,27,28,31-35$ presented opposite results to those observed above in verbal semantic and phonemic verbal fluency, working memory, planning and cognitive flexibility.

Perception and Attention In these two cognitive functions, only two articles ${ }^{16,19}$

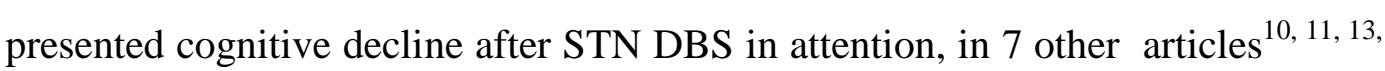
$18,20,27,28$ there were no significant changes.

Language Five articles ${ }^{13,20,21,27,33}$ showed a better or stable performance in language, in production of words ${ }^{12}$, tasks of semantic and phonemic verbal fluency $^{19}$ and vocabulary subtest from Weschler Abbreviated Scale ${ }^{24}$ worse postoperative performance.

Visuoconstructive and visuospacial skills Two articles ${ }^{16,19}$ presented decline in Visuoconstructive and visuospacial skills, while 3 articles $^{10,12,20}$ didn't show any difference pre and postoperative.

Motor and sensory coordination There was no decline $e^{9,13,26 .}$

\section{DISCUSSION}


This systematic review wanted to investigate the cognitive functions most affected by STN-DBS according to studies published in the last 10 years.

After analyzing the results of all 27 articles, it was observed that there was no consensus among studies on the effect of this surgery on patients. In most articles that evaluated global cognitive functioning, it was noticed that it improved or did not worsen, which is a good finding, since it does not have a direct purpose in non-motor symptoms. However, it can exert an improvement in cognition indirectly: once the subject has reduced or eliminated motor symptoms, his quality of life (QoL) improves, allowing him to return to previously abandoned tasks and habits. This behavior change can bring both cognitive and mood benefits. To confirm this hypothesis, it would be interesting to carry out a study comparing mood (anxiety, depression) before and after stimulation.

In general, we can relate this variance of results due to several factors that will be discussed below. The aggravation of cognitive disorders can be strongly predicted by neuropsychological tests in the early stage of the disease, with or without timely medical treatment. On average, $25-50 \%$ of PD patients develop MCI or dementia or progress from MCI to dementia within 5 years of diagnosis ${ }^{36}$. Thus, the selection of instruments is of paramount importance and needs to be accompanied by certain precautions. There is no specific protocol established with the most appropriate instruments for this evaluation, but knowing which functions are influenced by $\mathrm{PD}$, choosing the tests becomes easier. By establishing a protocol to be used by different studies and research centers, it would be easier to access, understand and compare results, leading to further investigation of the impaired aspects ${ }^{37}$. Any change indicated by the tests becomes subtle, as cognitive impairment detected in specialized tests is not commonly reported by patients, caregivers or health professionals. As stated above, QoL assessments in these patients show improvement, even when cognitive impairment is detected. In memory impairment, for example, there are several associated factors, such as the subject's age, duration of illness, and even executive functioning. In the case of the articles, the recognition memory ${ }^{9,13}$ and recall ${ }^{18,19,27,28}$ were impaired and this is observed in the literature, indicating a possible evolution to dementia in $\mathrm{PD}^{36}$. EFs are an umbrella concept that cover several aspects and, consequently, appear as the most evaluated functions and with the most discrepant results. Commonly, 
it appears to be impaired functions earlier in the disease and are directly associated with daily activities, which interferes with patients' QoL $^{38}$. Verbal fluency has worsened in many articles ${ }^{9-12,14-16,22-24,27,28,31,35}$ In fact, the worsening in the fluency task category is the most frequent cognitive sequela reported after DBS-STN. This is in accordance with recent evidence suggesting that STN is a potent regulator of basal ganglia and talamocortical limbic and associative circuits. Frontal lobe-related cognitive changes after DBS may be determined by the modulation of these distinct neural networks ${ }^{39}$. Impairment of visuospatial skills, in which motor involvement is the main criteria, even in the early stages of the disease, is already expected in PD and this contrasts with the fact that only 5 articles evaluated this function ${ }^{10,12,16,19,20}$.

One of the inclusion criteria was surgery to STN target and this was one of the limitations found in the studies. STNs are considered to produce more cognitive side effects in patients than when electrodes are implanted in the $\mathrm{GPi}^{39}$. Patients' ages ranged from 51 to 67 years at the time of surgery and the literature indicates a higher risk of cognitive decline associated with older age. The medication or stimulation parameters in the studies participants were not controlled, and there may be influence of a reduction in postoperative medication or the difference in DBS parameters. Added to this, we have the variation regarding follow-ups, making it difficult to understand and establish "specific milestones", in which we could predict an improvement or worsening of effects over the months / years. Thus, while certain articles had follow-up effects of $36^{22,24}, 84^{22,26}$ or up to $132^{19}$ months, others had data of $12^{24.26}, 6^{13,15,20,24}$ and up to $3^{17,22,31}$ months. This discrepancy makes a fair comparison and reliable analysis of the data unfeasible. Using the same battery of tests at such varying time intervals may give the impression of an improvement simply by the learning effect of a short-term reassessment and a marked worsening as the disease progresses naturally over a long-term reassessment ${ }^{37}$.

There was an absence of records of the daily cognitive decline subjective impact of the subjects associated with the motor symptoms ${ }^{28}$ and preoperative follow-up on cognitive function ${ }^{33}$. There was no further evaluation of impairments of daily life activities associated with the disease, which interfere with the subjective perspective of patients' abilities. These aspects are directly influenced when the 
motor improvement occurs. Thus, from the recovery of skills, new perspectives are idealized, which can have a repercussion on non-motor symptoms, such as cognitive ones. The angle of the surgical trajectory and the proximity of the STNDBS electrodes greatly influence the results that will be seen after the surgery: these aspects may be related to the changes in the cognitive and emotional functioning of the patients ${ }^{12,33}$. Therefore, the results are expected to vary from each other - as it has been seen, mainly due to variations in the characteristics of patients selected for surgery between different centers $\left(\operatorname{age}^{21,26}\right.$, preoperative state $^{10,24}$ and comorbidity with other conditions such as psychiatric disorders ${ }^{11,12}$ ) and, therefore, the conclusions are difficult to compare and to be analyzed.

Thus, it was not possible to establish a neuropsychological profile of the patient with PD and STN-DBS. This is quite worrying since patients with MCI in PD are more likely to progress to dementia as the disease progresses and it is necessary to understand which cognitive functions become impaired in this disease after DBS implantation to avoid miscalculating normal with worsening evolution. Much of this also occurs due to the lack of a specific PD assessment protocol ${ }^{37}$.

From the results of this review it became clear the need to establish a neuropsychological profile of PD patients to understand and investigate the effects on cognitive non-motor symptoms after the implantation of STN-DBS. In the next studies, it is intended to develop a neuropsychological battery and evaluate patients with PD and STN-DBS to discriminate the affected or not aspects of this subjects and to understand which factors contribute to the result.

Authors contributions. Eduarda Naidel Barboza e Barbosa: study concept and design, literature search, drafting and revising the manuscript; Helenice CharchatFichman: contribution during the writing process with suggestions and corrections. 


\section{REFERENCES}

1. Aarsland D, Larsen JP, Lim NG, Janvin C, Karlsen K, Tandberg E et al. Range of neuropsychiatric disturbances in patiens with Parkinson's disease. Journal of Neurology, Neurosurgery and Pshychiatry. 2009; 67, pp. 492-6.

2. Navarro-Peternella FM, Marcon SS. Qualidade de vida de indivíduos com Parkinson e sua relação com tempo de evolução e gravidade da doença. Revista Latino-Americana de Enfermagem. 2012; 20(2), pp. 384-391.

3. Cardoso F. Tratamento da Doença de Parkinson. Arquivos de Neuropsiquiatria. 2015; 53(1), pp. 1-10.

4. Machado FA, Reppold, CT. The effect of deep brain stimulation on motor and cognitive symptoms of Parkinson's disease - A literature review. Dementia and Neuropsychology. 2015; 9(1), pp. 24-31. doi: 10.1590/S198057642015DN91000005.

5. Pavão R. Aprendizagem Implícita e Doença de Parkinson. Dissertação de mestrado - Instituto de Biociências da Universidade de São Paulo. Departamento de Fisiologia, 2007.

6. Rita HJP, Reis AI. (Advisor) Dissociação da memória explícita e implícita da Doença de Parkinson. 2012. 56p. MSc. Dissertation - Human Sciences and Social College. Universidade do Algarve.

7. Nombela C, Rowe JB, Winder-Rhodes SE, Hampshire A, Owen AM, Breen DP et al. Genetic impact on cognition and brain function in newly diagnosed Parkinson's disease: ICICLE-PD study. Brain. 2014; 137: 2625-2631. doi: 10.1093/brain/awu201.

8. Lewis, CJ; Maier, F; Eggers, C; Pelzer, EA; Maarouf, M; Moro, E et al. Parkinson's disease patients with subthalamic stimulation and carers judge quality of life differently. Parkinsonism Related Disorders. 2014; 20(5): 514519. doi: 10.1016/j.parkreldis.2014.02.009. 
9. Klempírová O, Jech R, Urgosík D, Klempír J, Spacková N, Roth J et al. Deep brain stimulation of the subthalamic nucleus and cognitive functions in Parkinson's disease. Prague medical report, 2007; 108(4): 315-23.

10. Cilia R, Siri C, Marotta G, Gaspari D, Landi A, Mariani CB et al. Brain networks underlining verbal fluency decline during STN-DBS in Parkinson's disease: An ECD-SPECT study. Parkinsonism and Related Disorders. 2007; 13(5): 290-294.

11. Castelli L, Lanotte M, Zibetti M, Caglio M, Rizzi L, Ducati A, et al. Apathy and verbal fluency in STN-stimulated PD patients. Journal of Neurology. 2007; 254(9): 1238-1243.

12. Witt K, Daniels C, Reiff J, Krack P, Volkmann J, Pinsker MO, et al. Neuropsychological and psychiatric changes after deep brain stimulation for Parkinson's disease: a randomised, multicentre study. Lancet Neurology. 2008; 7(7): 605-614.

13. Heo JH, Lee KM, Paek SH, Kim MJ, Lee JY, Kim JY et al. The effects of bilateral Subthalamic Nucleus Deep Brain Stimulation (STN DBS) on cognition in Parkinson disease. Journal of the Neurological Sciences. 2008; 273(1): 19-24.

14. R. Zangaglia, C. Pacchetti, C. Pasotti, F. Mancini, D. Servello, E. Sinforiani, S. Cristina, M. Sassi, G. Nappi, Deep brain stimulation and cognitive functions in Parkinson's disease: A three-year controlled study. Movement Disorders, 2009; 11: 1621-1628.

15. Daniels C, Krack P, Volkmann J, Pinsker MO, Krause M, Tronnier V et al. Risk factors for executive dysfunction after subthalamic nucleus stimulation in Parkinson's disease. Movement Disorders. 2010; 25(11): 1583-1589.

16. Castelli L, Rizzi L, Zibetti M, Angrisano S, Lanotte M, Lopiano L. Motor and cognitive outcome in patients with Parkinson's disease 8 years after subthalamic implants. Parkinsonism and Related Disorders. 2010; 16(2): 115118. 
17. Israeli-Korn $\mathrm{S}$, Hocherman $\mathrm{S}$, Hassin-Baer $\mathrm{O}$, Cohen $\mathrm{R}$, Inzelberg $\mathrm{R}$. Subthalamic Nucleus Deep Brain Stimulation Does Not Improve VisuoMotor Impairment in Parkinsons Disease. PLoS One. 2013; 8(6): e65270. doi:10.1371/journal.pone.0065270.

18. Asahi T, Nakamichi N, Takaiwa A, Kashiwazaki D, Koh M, Dougu N et al. Impact of bilateral subthalamic stimulation on motor / cognitive functions in Parkinson's disease. Neurologia medico-chirurgica. 2014; 54(7): 529-536.

19. Rizzone MG, Fasano A, Daniele A, Zibetti M, Merola A, Rizzi L et al. Longterm outcome of subthalamic nucleus DBS in Parkinson's disease: From the advanced phase towards the late stage of the disease? Parkinsonism and Related Disorders. 2014; 20(4): 376-381.

20. Tang V, Zhu C, Cannon C, Chan D, Lau C, Chan A et al. Evidence of improved immediate verbal memory and diminished category fluency following STN-DBS in Chinese-Cantonese patients with idiopathic Parkinson's disease. Neurological Sciences. 2015; 36(8): 1371-1377.

21. Tremblay C, Macoir J, Langlois M, Cantin L, Prud'homme M, Monetta L. The effects of subthalamic deep brain stimulation on metaphor comprehension and language abilities in Parkinson's disease. Brain and Language. 2015; 141: 103-109.

22. York MK, Wilde EA, Simpson R, Jankovic J. Relationship between neuropsychological outcome and DBS surgical trajectory and electrode location. Journal of the Neurological Sciences. 2009; 287(1): 159-171.

23. Williams A, Gill S, Varma T, Jenkinson C, Quinn N, Mitchell R et al. Deep brain stimulation plus best medical therapy versus best medical therapy alone for advanced Parkinson's disease (PD SURG trial): a randomised, open-label trial. Lancet Neurology. 2010; 9: 581-591.

24. Kim WJ, Jeon BS, Yun WY, Kim YE, Yang HJ, Paek SH. Initial cognitive dip after subthalamic deep brain stimulation in Parkinson disease. Journal of Neurology. 2013; 260(8): 2130-2133. 
25. Markser A, Maier F, Lewis C, Dembek T, Pedrosa D, Eggers C et al. Deep brain stimulation and cognitive decline in Parkinson's disease: The predictive value of electroencephalography. Journal of Neurology. 2015; 262(10): 22752284.

26. Krishnan S, Prasad S, Pisharady K, Sarma G, Sarma S, Kishore A. The decade after subthalamic stimulation in advanced Parkinson's disease: A balancing act. (Original Article) (Report) Neurology India. 2016; 64(1): 81.

27. Yágüez L, Costello A, Moriarty J, Hulse N, Selway R, Clough C. Cognitive predictors of cognitive change following bilateral subthalamic nucleus deep brain stimulation in Parkinson's disease. Journal of Clinical Neuroscience. 2014; 21(3): 445-450.

28. Fasano A, Romito LM, Daniele A, Piano C, Zinno M, Bentivoglio AR Neuropsychological changes 1-year after subthalamic DBS in PD patients: A prospective controlled study. Brain. 2010; 133(9): 2664-2676.

29. Lueken U, Schwarz M, Hertel F, Schweiger E, Wittling W, Impaired performance on the Wisconsin Card Sorting Test under left- when compared to right-sided deep brain stimulation of the subthalamic nucleus in patients with Parkinson's disease. Journal of Neurology. 2008; 255(12): 1940-1948.

30 van Wouwe NC, Ridderinkhof KR, van ven Wildenberg WPM, Band GPH, Abisogun A, Elias WJ et al. Deep Brain Stimulation of the Subthalamic Nucleus Improves Reward-Based Decision-Learning in Parkinson's Disease. Frontiers in Human Neuroscience. 2011; 5.

31. Houvenaghel JF,Jeune F, Dondaine T, Esquevin A, Robert G, Péron J, et al. Reduced Verbal Fluency following Subthalamic Deep Brain Stimulation: A Frontal-Related Cognitive Deficit? PLoS One. 2015; 10(10).

32. Pham UHG, Andersson, Toft M, Pripp AH, Konglund AE, Dietrichs. SelfReported Executive Functioning in Everyday Life in Parkinson's Disease after Three Months of Subthalamic Deep Brain Stimulation. Parkinson's Disease. 2015; 2015, Article ID 461453, dx.doi.org/10.1155/2015/461453. 
33. Ventre-Dominey J, Mollion H, Thobois S, Broussolle E. Distinct effects of dopamine vs STN stimulation therapies in associative learning and retention in Parkinson disease. Behavioural Brain Research. 2016; 302, 131-141.

34. Alberts JL, Voelcker - Rehage C, Hallahan K, Vitek M, Bamzai, Vitek JL. Bilateral subthalamic stimulation impairs cognitive-motor performance in Parkinson's disease patients. Brain. 2008; 131(12): 3348-3360.

35. Vonberg I, Ehlen F, Fromm O, Kühn A, Klostermann F. Deep Brain Stimulation of the Subthalamic Nucleus Improves Lexical Switching in Parkinsons Disease Patients. PLoS One. 2006; 11(8).

36. Massano J, Garret C. Deep brain stimulation and cognitive decline in Parkinon's disease: a clinical review. Frontiers in Neurology. 2012; 3(66).

37. Barbosa ENB, Charchat-Fichman H. Systematic review of neuropsychological instruments used in subthalamic nucleus deep brain stimulation in Parkinson's disease patients. Dement Neuropsychol. 2019; 13(2): 162-171.

38. Ding W, Ding JL, Li FF, Han Y, Mu L. Neurodegeneration and cognition in Parkinson's disease: a review. Eur Rev med Pharmacol Sci. 2015; 19: 22752281.

39. Temel Y, Blokland, Steinbusch HMW, Visser-Vander V. The functional role of the subthalamic nucleus in cognitive and limbic circuits. Progress in Neurobiology. 2005; 76(6): 393-413. 


\section{ARTICLE 3}

Eduarda Naidel Barboza e Barbosa, Larissa Marques Francisco, Mariana Spitz and Helenice Charchat-Fichman. CompCog has high accuracy to identify cognitive symptoms in Parkinson's Disease patients. (in preparation).

\section{ABSTRACT}

Introduction: Currently, we can observe the help of technology in the diagnosis and treatment of several diseases. In clinical neuropsychology, we have computerized neuropsychological batteries aimed at both neuropsychological assessment and rehabilitation. CompCog is one of those instruments that uses the iPad as an interface. Objective: The aim of this study is to investigate the accuracy of the CompCog to screen Parkinson Disease among patients assisted in a neurology outpatient clinic at a public hospital in Rio de Janeiro city and develop cutoff points for this disease. Method: There was 32 patients with PD from a public hospital in Rio de Janeiro city and 32 healthy subjects from a social program that is offered by the government of Rio de Janeiro city (Casas de Convivência e Lazer para Idosos). It was used several instruments (Brief Cognitive Screening Battery that includes Mini-Mental State Examination, Figure Memory Tests, Clock Drawing Test and Animal Verbal Fluency Test, besides Beck Depression Inventory) for the neuropsychological assessment and CompCog for clinical validation. Results: The results showed that time variables, like choice reaction time and total time, were good to discriminate the sample of healthy subjects from the sample of people with PD, mainly in tasks of choice of stimulus, implicit learning, visuospatial memory, memory and recognition of faces and inhibitory control. Conclusion: These findings suggest that time variables are good measures to evaluate PD patients and CompCog is a useful tool for screen PD cognitive impairments.

Keywords: Neuropsychological Assessment; Neuropsychology Computadorized Battery; CompCog; Parkinson Disease 


\section{CompCog has high accuracy to identify cognitive symptoms in Parkinson's Disease patients}

Parkinson's disease (PD), being the second most common neurodegenerative disease today, needs to have all its aspects well investigated, including non-motor symptoms: cognition. It is increasingly important to develop and clinically validate instruments that improve the neuropsychological assessment of these conditions. To characterize a sample and identify the compromises to be analyzed, a screening of the patient's cognitive functioning is performed. However, comparing cognitive data from different populations and using different tests generates conflicts in the literature, mainly because they use screening instruments that do not have the sensitivity to detail cognitive functioning sufficiently (Heluani, 2014). Computerized tests batteries have been applied in several clinical populations, helping in diagnoses, drug, and psych educative interventions. These studies appear in both international and national literature, however more frequently in international studies. This evidence corroborates the relevance regarding the validation of computerized batteries benefiting from the new technologies applied to Psychology (Charchat et al, 2001).

CompCog is a computerized neuropsychological battery consisting of 8 subtests (Simple Reaction Time, Choice Reaction Time, Implicit Learning Test, Visuospatial Short-Term Memory, Face Recognition and Memory, Stroop Test, Inhibitory Control and Survey), which assesses different cognitive domains: attention, memory, executive functions, perception and processing time information. It was initially called the Bateria de Testes Neuropsicológicos Computadorizados (BTNC) and evaluated visual perception, attention, anterograde episodic memory, short-term memory and processing time information in 6 subtests (Charchat, 1999). The MEL Professional version 2.0 program (Schneider, 1995) was used and Charchat et al (2001) carried out an initial study to investigate clinical markers of early Alzheimer's Disease (AD). It was found that both episodic memory, short-term memory, and choice reaction time substances were sensitive and specific to discriminate between groups of people with probable mild AD and healthy people. Subsequently, a screening 
version called Computerized Cognitive Screening test (CompCogs) was created with the same characteristics as the initial version, but reducing the application time by 25 minutes, requiring only 15 minutes for its administration. Its validity for the early diagnosis of $\mathrm{AD}$ was investigated and proved to be highly sensitive and specific for this diagnosis (Fichman et al, 2008). Since 2011, CompCog has been administered via a portable computing device that operates on iOS operating system - iPad. The iPad is a small tablet and easily transported to different places, making its use even more practical. The use of tablets, especially the iPad, has increased considerably in recent years.

The validation of this neuropsychological instrument that assess the main cognitive functions (attention, memory, perception, speed of information processing) is a great achievement for PD patients who previously only had access to instruments that required capacities that were not compatible with impairments resulting from the disease, but not related to cognitive functioning motor symptoms. This equipment uses only the touchscreen, which makes the automation of commands accessible to individuals who do not normally use traditional computers.

In the context of neuropsychology, especially in Brazil, the search for the validation of tests and computerized measures is essential for two main reasons: the scarcity of tests validated in Brazil (Atalaia-Silva and Lourenço, 2008) and the verification of the usefulness of computerized evaluation in investigation of cognitive impairments in neurological and psychiatric diseases (Johnson et al, 2008). In this study, it is administered in people with PD to allow this assessment to be capable, even with the motor losses inherent to the condition. This study aims to investigate the accuracy of the CompCog to screen PD among patients assisted in a neurology outpatient clinic at a public hospital in Rio de Janeiro city.

\section{METHODOLOGY}

\section{Sample}

The sample for this study consisted of neurology outpatients of a public hospital in Rio de Janeiro city. Thirty-two patients with PD diagnosis and 32 healthy subjects were investigated. The PD diagnosis was the gold standard 
adopted by the medical staff based on the UK Parkinson's Society Brain Bank (Hughes et al, 1992; Litvan et al, 2012).

The patients were referred by the neuropsychologist, which performed a screening with an evaluation protocol established. The inclusion criteria to participate in the study was: a) be a user of the hospital's neurology service, b) have a PD diagnosis and c) be over than 45 years of age. Were excluded patients a) presenting serious systemic diseases (hormonal, brain disorders, among others that can cause cognitive decline) b) a recent history of alcohol or other drug dependence, c) use of psychotropics that affect cognition, such as benzodiazepines, d) existence of cardiovascular diseases, hypertension and diabetes no controlled, e) visual and/or hearing disorders without correction; f) presence of current or previous neurological diseases and g) fulfill dementia criteria, based on the clinical evaluation of the medical team.

The group of 32 healthy subjects was selected from a social program offered by the government of Rio de Janeiro city of the Special Secretariat for Healthy Aging and Quality of Life of Rio de Janeiro city. The inclusion criteria to participate in the study was: a) be a user of the Casas de Convivência, b) be over than 45 years of age, c) having no neurological and/or psychiatric illness. Were excluded people a) presenting serious systemic diseases (hormonal, brain disorders, among others that can cause cognitive decline), b) a recent history of alcohol or other drug dependence, c) use of psychotropics that affect cognition, such as benzodiazepines; d) existence of cardiovascular diseases, hypertension and diabetes no controlled, e) visual and/or hearing disorders without correction; f) presence of current or previous neurological diseases and g) fulfill dementia criteria, based on the clinical evaluation of the medical team.

\section{Ethical aspects}

This study was approved by the Research Ethics Committees of the the State Servers Federal Hospital from Rio de Janeiro city (3.271.273) and Catholic Pontifical University from Rio de Janeiro city (21/2019). People participated in this research by signing a term of informed consent, according to Resolution $466 / 12$ of the National Health Council, which deals with the guidelines and standards for research involving humans. 


\section{Instruments}

The following instruments were applied: a) structured interview (with questions regarding clinical and socio-demographic aspects), b) CompCog - IPad version (Table 1) and c) Brief Cognitive Screening Battery that includes the following tests: Mini-Mental State Examination (MMSE), Figure Memory Tests (FMT), Clock Drawing Test (TDR), Animal Verbal Fluency Test (AVFT) and Beck Depression Inventory (BDI).

Table 1. CompCog subtests, variables and description

\begin{tabular}{|c|c|c|}
\hline Subtests & Variables & Description \\
\hline $\begin{array}{c}\text { Simple Reaction } \\
\text { Time }\end{array}$ & Median reaction time & $\begin{array}{l}\text { There is a white rectangle at the } \\
\text { bottom of the screen. As soon as a } \\
\text { white square appears in the middle } \\
\text { of the screen, the person should } \\
\text { touch the rectangle. }\end{array}$ \\
\hline $\begin{array}{c}\text { Choice Reaction } \\
\text { Time }\end{array}$ & $\begin{array}{l}\text { Median reaction time, } \\
\text { correct answers and } \\
\text { revised median reaction } \\
\text { time (choice reaction time } \\
\text { - simple reaction time) }{ }^{\star}\end{array}$ & $\begin{array}{l}\text { There are two rectangles, a white } \\
\text { and an orange one, at the bottom of } \\
\text { the screen. As a white or orange } \\
\text { square appears in the middle of the } \\
\text { screen, the person should touch the } \\
\text { rectangle of the same color. }\end{array}$ \\
\hline $\begin{array}{c}\text { Implicit Learning } \\
\text { Test }\end{array}$ & $\begin{array}{l}\text { Median reaction time in } \\
\text { each of five tasks and } \\
\text { implicit learning (median } \\
\text { reaction time in sequence } \\
4-\text { median reaction time } \\
\text { in sequence } 1)^{\star}\end{array}$ & $\begin{array}{l}\text { There are } 10 \text { grey squares } \\
\text { distributed on the screen. One } \\
\text { square becomes white at a time and, } \\
\text { as the person touches it, another } \\
\text { one lights up. There is a fixed } \\
\text { sequence of } 25 \text { squares that is } \\
\text { repeated } 4 \text { times and one last } \\
\text { random sequence of also } 25 \\
\text { squares. The difference between } \\
\text { reactions of subsequent sequences } \\
\text { are used as an implicit learning } \\
\text { measure. }\end{array}$ \\
\hline $\begin{array}{l}\text { Visual and Spatial } \\
\text { Short-Term Memory }\end{array}$ & $\begin{array}{l}\text { Correct answers, direct } \\
\text { order SPAN, reaction time } \\
\text { in direct order, inverse } \\
\text { order SPAN and reaction } \\
\text { time in direct order }\end{array}$ & $\begin{array}{l}\text { There are, as there were in the last } \\
\text { test, } 10 \text { grey squares distributed on } \\
\text { the screen. One will become white at } \\
\text { a time, making a sequence that must } \\
\text { be reproduced. The sequence } \\
\text { increases in number if the person } \\
\text { gets two of four attempts right. The } \\
\text { test starts with a message stating } \\
\text { the type of sequence - first forward } \\
\text { and then reverse - and the number } \\
\text { of squares that will appear in } \\
\text { sequence - from } 2 \text { to } 8 \text {. When the } \\
\text { forward sequences end, the reverse } \\
\text { sequences starts. Results are } \\
\text { measured by the span reached. }\end{array}$ \\
\hline
\end{tabular}




\begin{tabular}{|c|c|c|}
\hline and Memory & $\begin{array}{l}\text { median reaction time for } \\
\text { each of the four tasks }\end{array}$ & $\begin{array}{l}\text { faces are presented for } 30 \text { seconds } \\
\text { on the screen with the instruction for } \\
\text { memorizing the faces. After that the } \\
\text { person should choose between } 10 \\
\text { pairs of faces which one was among } \\
\text { those initially shown for } \\
\text { memorization. The task is repeated } \\
\text { three times in a row and again after } \\
20 \text { minutes. }\end{array}$ \\
\hline $\begin{array}{c}\text { Inhibitory Control } \\
\text { Test }\end{array}$ & $\begin{array}{l}\text { Median reaction time, } \\
\text { correct answers, correct } \\
\text { answers median reaction } \\
\text { time, errors median } \\
\text { reaction time and errors }\end{array}$ & $\begin{array}{l}\text { Squares of different colors will } \\
\text { appear in the middle of the screen } \\
\text { for one second each, the white ones } \\
\text { should be avoided. }\end{array}$ \\
\hline Stroop Test & $\begin{array}{l}\text { Interference, median } \\
\text { reaction time and errors } \\
\text { for each of the three } \\
\text { tasks }\end{array}$ & $\begin{array}{l}\text { This test includes three tasks, like } \\
\text { the original Stroop paradigm. All } \\
\text { tasks have } 4 \text { rectangles (green, } \\
\text { red, blue and yellow) located at the } \\
\text { bottom of the screen. The person } \\
\text { should touch the one matching the } \\
\text { stimuli (first: a colored square, } \\
\text { second: fruit names written in } \\
\text { different colors than the actual } \\
\text { color of the fruit, and third: color } \\
\text { names that are written in another } \\
\text { color) that appears in the middle of } \\
\text { the screen considering its color. }\end{array}$ \\
\hline Survey Test & $\begin{array}{l}\text { Median reaction time, } \\
\text { correct answers, } \\
\text { reaction time of correct } \\
\text { answers, errors and } \\
\text { reaction time of errors } \\
\text { for each of the three } \\
\text { tasks }\end{array}$ & $\begin{array}{l}\text { Squares of different colors will } \\
\text { appear in the middle of the screen } \\
\text { for one second each. Results are } \\
\text { measured by reaction time and the } \\
\text { percentage of errors and correct } \\
\text { answers. }\end{array}$ \\
\hline
\end{tabular}

* possible variables to be calculated

\section{Procedures}

The Neurology outpatient clinic of the Federal Hospital of the State Servers (FHSS) was the place where the research was carried out and the PD patient received a call scheduling the evaluation. Once in the hospital for his appointment, he signed the Free and Informed Consent (FIC) and, subsequently, the evaluation started with an anamnesis (interview), evaluating the inclusion and exclusion criteria of the project and starting the application of the instruments. For healthy subjects from the Casas de Convivência, neuropsychological assessments were carried out at the institution itself. 


\section{Data Analysis}

Comparisons between means of demographic, clinical profile data and CompCog results were performed through the t-test or chi-square test. ROC curves were used to evaluate the accuracy of each test and define cutoff points for each variable. A diagnosis model using the short battery was proposed from the logistic regression analyses. That model generated an equation that determined the probability for each individual to present clinically probable diagnosis of PD. These results classified the subjects and defined the sensitivity and specificity of the computerized neuropsychological battery for the diagnosis of PD in the studied sample.

These data analyses were performed with the aid of statistical software Statistical Package for Social Sciences (SPSS) version 22.0. For all analysis the value of significance was set at $\mathrm{p}<0.05$.

\section{RESULTS}

Below there is a description of the two groups, both the sociodemographic data (Table 2) and the neuropsychological profile (Table 3) based on the Brief Cognitive Screening Battery.

\section{Table 2. Socio-demographic data}

\begin{tabular}{|c|c|c|}
\hline & Control group $(n=32)$ & PD group $(n=32)$ \\
\hline Gender & $25 \mathrm{~W} \times 7 \mathrm{M}$ & $15 \mathrm{~W} \times 17 \mathrm{M}$ \\
\hline Age & $\begin{array}{c}\text { 53-63y } 6.3 \% \\
64-74 y \quad 25 \% \\
\text { Above } 75 y \quad 18.8 \%\end{array}$ & $\begin{array}{c}\text { 42-52y } 9.4 \% \\
53-63 y \quad 12.5 \% \\
64-74 \text { y } 21.9 \% \\
\text { Above } 75 y \quad 6.3 \%\end{array}$ \\
\hline Schooling & $\begin{array}{c}\text { Elementary school } 3.2 \% \\
\text { High school } 10.9 \% \\
\text { Graduation } 10.9 \% \\
\text { Post-araduation } 25 \%\end{array}$ & $\begin{array}{c}\text { Illiterate } 3.1 \% \\
\text { Elementary school } 18.7 \% \\
\text { High school } 17.2 \% \\
\text { Graduation } 7.8 \%\end{array}$ \\
\hline
\end{tabular}

W: women, M: men, y: years.

The mean age of PD patients was $64( \pm 10.18)$ years and $8.77( \pm 4.10)$ years of schooling. The mean age of the control group was $71.48( \pm 6.90)$ years and $14.32( \pm 4.13)$ years of schooling.

Table 3. Neuropsychologic profile 


\begin{tabular}{rcc}
\hline & Control group $(\mathbf{n}=\mathbf{3 2})$ & PD group $(\mathbf{n}=\mathbf{3 2})$ \\
\hline MMSE & $27.48( \pm 1.98)$ & $25.12( \pm 2.79)$ \\
MFT (Nomination) & 10 & $10.33( \pm 2.10)$ \\
(Incidental Memory) & $5.81( \pm 1.47)$ & $5.33( \pm 1.73)$ \\
(Mem Imediata 1) & $8.32( \pm 1.40)$ & $7.55( \pm 1.30)$ \\
(Mem Imediata 2) & $9.13( \pm 1.02)$ & $8.39( \pm 1.25)$ \\
(Late Memory) & $8.58( \pm 1.54)$ & $7.67( \pm 1.78)$ \\
(Recognition) & $9.90( \pm 0.30)$ & $9.94( \pm 0.36)$ \\
Animals FVT & $20.68( \pm 4.02)$ & $17.21( \pm 3.86)$ \\
CDT & $7.16( \pm 2.45)$ & $4.42( \pm 1.07)$ \\
\hline
\end{tabular}

It was observed significant difference between groups only in CDT $[\mathrm{t}(55)=5.288, \mathrm{p}<.01] . \quad \mathrm{T}$ test did not show difference between MMSE [ $\mathrm{t}(62)=3.881, \mathrm{p}=.087]$, Nomination [ $\mathrm{t}(62)=-, 883, \mathrm{p}=.051]$, Incidental Memory $[\mathrm{t}(62)=1.177, \mathrm{p}=.478]$, Late Memory [t(62)=2.188, $\mathrm{p}=.596]$, Recognition $[\mathrm{t}(60)=-$ $.383, \mathrm{p}=.505]$ and AVFT $[\mathrm{t}(62)=3.517, \mathrm{p}=.919]$.

Below are presented and compared the results of the CompCog of each group (Table 4):

Table 4. Description and comparison of CompCog results of both groups

\begin{tabular}{rrcc}
\hline & Control group $(\mathbf{n}=\mathbf{3 2})$ & PD group $(\mathbf{n}=\mathbf{3 2})$ \\
\hline & Median Time & $468.32( \pm 307.03) \mathrm{ms}$ & $818.79( \pm 350.53) \mathrm{ms}$ \\
Total Time & $59.66( \pm 39.40) \mathrm{s}$ & $95.93( \pm 41.51) \mathrm{s}$ \\
& & & \\
Choice Reaction Time & & & \\
& Median Time & $684.97( \pm 128.77) \mathrm{ms}$ & $1060.62( \pm 185.91) \mathrm{ms}$ \\
& Total Time & $72.63( \pm 14.79) \mathrm{s}$ & $109.91( \pm 21.94) \mathrm{s}$ \\
& Correct Answers & $98.19( \pm 1.89)$ & $97.21( \pm 3.08)$ \\
& & \\
Implicit Learning Test & & $706.53( \pm 125.29) \mathrm{ms}$ & $994.36( \pm 196.28) \mathrm{ms}$ \\
Reaction Median Time Seq 1 & Total Time Seq 1 & $37.56( \pm 6.54) \mathrm{s}$ & $54.47( \pm 12.53) \mathrm{s}$ \\
Reaction Median Time Seq 2 & $648.14( \pm 115.16) \mathrm{ms}$ & $944.63( \pm 161.38) \mathrm{ms}$ \\
Total Time Seq 2 & $32.81( \pm 5.79) \mathrm{s}$ & $48.60( \pm 9.71) \mathrm{s}$ \\
Reaction Median Time Seq 3 & $624.17( \pm 114.34) \mathrm{ms}$ & $934.67( \pm 172.13) \mathrm{ms}$ \\
Total Time Seq 3 & $31.70( \pm 5.43) \mathrm{s}$ & $48.50( \pm 10.23) \mathrm{s}$ \\
Reaction Median Time Seq 4 & $611.25( \pm 106.88) \mathrm{ms}$ & $913.52( \pm 159.88) \mathrm{ms}$ \\
Total Time Seq 4 & $31.49( \pm 5.02) \mathrm{s}$ & $47.13( \pm 8.99) \mathrm{s}$ \\
Reaction Median Time Seq 5 & $645.28( \pm 86.57) \mathrm{ms}$ & $941.86( \pm 192.13) \mathrm{ms}$ \\
Total Time Seq 5 & $32.18( \pm 4.31) \mathrm{s}$ & $49.53( \pm 14.14) \mathrm{s}$ \\
Implicit Learning & $.793( \pm .250)$ & $.922( \pm .093)$ \\
Shert-Term Visuospatial Memory & & \\
\hline
\end{tabular}




\begin{tabular}{|c|c|c|}
\hline $\begin{array}{r}\text { Reaction Median Time } \\
\text { Total Time } \\
\text { Correct Answers } \\
\text { Longest Direct Sequence } \\
\text { Longest Indirect Sequence }\end{array}$ & $\begin{array}{c}679.81( \pm 248.88) \mathrm{ms} \\
150.26( \pm 64.31) \mathrm{s} \\
67.84( \pm 14.07) \\
4.10( \pm 1.49) \\
3.74( \pm 1.13)\end{array}$ & $\begin{array}{c}1148.41( \pm 785.98) \mathrm{ms} \\
114.29( \pm 60.10) \mathrm{s} \\
56.83( \pm 23.34) \\
3.36( \pm 1.55) \\
2.64( \pm 1.31)\end{array}$ \\
\hline \multicolumn{3}{|l|}{ Face Recognition and Memory } \\
\hline $\begin{array}{r}\text { Reaction Median Time } \\
\text { Total Time } \\
\text { Correct Answers } \\
\text { First Block Reaction Median Time } \\
\text { First Block Correct Answers } \\
\text { Second Block Reaction Median Time } \\
\text { Second Block Correct Answers } \\
\text { Third Block Reaction Median Time } \\
\text { Third Block Correct Answers } \\
\text { Late Test Reaction Median Time } \\
\text { Late Test Correct Answers }\end{array}$ & $\begin{array}{c}1513.15( \pm 317.033) \mathrm{ms} \\
72.58( \pm 19.58) \mathrm{s} \\
96.77( \pm 6.48) \\
2088.03( \pm 764.47) \mathrm{ms} \\
92.71( \pm 12.50) \\
1530.03( \pm 362.89) \mathrm{ms} \\
97.29( \pm 13.32) \\
1390.24( \pm 267.64) \mathrm{ms} \\
99.38( \pm 2.45) \\
1389.74( \pm 324.29) \mathrm{ms} \\
97.71( \pm 4.72)\end{array}$ & $\begin{array}{c}2399.12( \pm 1456.15) \mathrm{ms} \\
108.37( \pm 55.06) \mathrm{s} \\
84.57( \pm 19.75) \\
3302.71( \pm 2218.25) \mathrm{ms} \\
80( \pm 20.67) \\
2402.51( \pm 1461.63) \mathrm{ms} \\
86.52( \pm 25.34) \\
2168.38( \pm 1271.39) \mathrm{ms} \\
86.09( \pm 21.48) \\
2035.81( \pm 1071.13) \mathrm{ms} \\
85.65( \pm 17.01)\end{array}$ \\
\hline \multicolumn{3}{|l|}{ Inhibitory Control Test } \\
\hline $\begin{array}{r}\text { Reaction Median Time } \\
\text { Total Time } \\
\text { Correct Answers }\end{array}$ & $\begin{array}{c}627.08( \pm 93.82) \mathrm{ms} \\
70.46( \pm 6.89) \mathrm{s} \\
94.96( \pm 14.29)\end{array}$ & $\begin{array}{c}743.64( \pm 131.19) \mathrm{ms} \\
78.81( \pm 8.82) \mathrm{s} \\
90.09( \pm 14.70)\end{array}$ \\
\hline \multicolumn{3}{|l|}{ Stroop Test } \\
\hline $\begin{array}{r}\text { Total Time } \\
\text { First Block Reaction Median Time } \\
\text { First Block Correct Answers } \\
\text { Second Block Reaction Median Time } \\
\text { Second Block Correct Answers } \\
\text { Third Block Reaction Median Time } \\
\text { Third Block Correct Answers } \\
\text { Stroop Effect }\end{array}$ & $\begin{array}{c}304.95( \pm 62.14) \mathrm{s} \\
844.80( \pm 133.47) \mathrm{ms} \\
99.48( \pm 0.77) \\
934.39( \pm 174.44) \mathrm{ms} \\
98.06( \pm 4.34) \\
1054.12( \pm 249.00) \mathrm{ms} \\
92.42( \pm 19.24) \\
1.30( \pm .24)\end{array}$ & $\begin{array}{c}396.14( \pm 141.96) \mathrm{s} \\
1061.73( \pm 269.45) \mathrm{ms} \\
95.45( \pm 16.68) \\
1177.28( \pm 338.92) \mathrm{ms} \\
96.63( \pm 4.77) \\
1299.80( \pm 395.23) \mathrm{ms} \\
86.73( \pm 25.26) \\
1.20( \pm .20)\end{array}$ \\
\hline \multicolumn{3}{|l|}{ Survey } \\
\hline $\begin{array}{r}\text { Total Time } \\
\text { First Block Reaction Median Time } \\
\text { First Block Correct Answers } \\
\text { Second Block Reaction Median Time } \\
\text { Second Block Correct Answers } \\
\text { Third Block Reaction Median Time } \\
\text { Third Block Correct Answers }\end{array}$ & $\begin{array}{c}124.07( \pm 7.76) \mathrm{s} \\
663.65( \pm 87.62) \mathrm{ms} \\
96.04( \pm 12.72) \\
626.91( \pm 95.34) \mathrm{ms} \\
97.36( \pm 5.58) \\
625.17( \pm 86.57) \mathrm{ms} \\
94.21( \pm 6.57)\end{array}$ & $\begin{array}{c}135.70( \pm 8.90) \mathrm{s} \\
653.27( \pm 268.16) \mathrm{ms} \\
86.73( \pm 25.26) \\
682.21( \pm 237.25) \mathrm{ms} \\
86.64( \pm 16.08) \\
680.17( \pm 231.16) \mathrm{ms} \\
80.01( \pm 24.89)\end{array}$ \\
\hline
\end{tabular}

After comparing the results of the healthy and PD groups, a significant difference was observed in the following variables: Choice Reaction Time (CRT) median reaction time $(\mathrm{MRT})[\mathrm{t}(47.451)=-8.931, \mathrm{p}=.010]$, CRT total time $(\mathrm{TT})$ [t(46.641)=-7.572, $\mathrm{p}=.004]$, Implicit Learning Test (ILT) first sequence MRT [t(45.040)=-6.634, $\mathrm{p}=.008]$, ILT first sequence $\operatorname{TT}[\mathrm{t}(39.743)=-6.387, \mathrm{p}=.001]$, ILT second sequence MRT [t(48.342)=-8.046, p=.003], ILT second sequence TT [ $\mathrm{t}(43.107)=-7.487, \mathrm{p}=.002]$, ILT third sequence MRT [t(46.205)=-8.071, $\mathrm{p}=.002]$, ILT third sequence TT [t(40.174)=-7.757, $\mathrm{p}<.001]$, ILT fourth sequence MRT $[\mathrm{t}(46.392)=-8.444, \mathrm{p}=.004]$, ILT fourth sequence TT $[\mathrm{t}(41.407)=-8.129, \mathrm{p}<.001]$, 
ILT fifth sequence MRT [t(36.701)=-7.509, $\mathrm{p}<.001]$, ILT fifth sequence TT [t(31.530)=-6.237, $\mathrm{p}<.001]$, Visuospatial Short-Term Memory MRT direct sequence [t(31.877)=-3.021, p=.002], Face Recognition and Memory (FRM) MRT [t(29.313)=-3.153, p=.003], FRM TT [t(33.130)=-3.259,p=.004], FRM first block MRT [t(32.764)=-2.754, p=002], FRM second block MRT [t(30.007)=3.074, p=.001], FRM third block MRT [t(29.163)=-3.176, p=.006], FRM late test MRT [t(30.151)=-3.016, p=.008), Control Inhibitory Test MRT [t(46.353)=3.840, $\mathrm{p}=.025)$, Stroop Test (ST) TT [t(31.391)=-2.989, $\mathrm{p}=0.47]$, ST first block MRT [t(33.392)=-3.678, p=.042), Survey first block MRT [t(26.818)=-.520, $\mathrm{p}=.006]$, Survey second block MRT [t(28.765)=-1.076, p=0.19] and Survey third block MRT [t $(28.012)=-1.107, \mathrm{p}=.029]$.

The cutoff points, the sensibility, and specificity for each variable were generated by a Receiver Operating Characteristic (ROC) analysis and presented in Table 5. Only those variables with an area under the curve (AUC) $>.8$ and pvalue $<.05$ were included in the table 5 . Sensitivity was prioritized over specificity, and it's preferable to find false positives during the neuropsychological assessment at first and, subsequently, investigate better if there is suspicion of cognitive impairment.

Table 5. Cut-off scores of the most discriminative significant variables

\begin{tabular}{cccccc}
\hline $\begin{array}{c}\text { Subtests - } \\
\text { Variable }\end{array}$ & $\begin{array}{c}\text { Area under the } \\
\text { curve, Range 95\% } \\
\text { confidence interval }\end{array}$ & $\mathbf{p}$ & $\begin{array}{c}\text { Cut-off } \\
\text { scores }\end{array}$ & $\begin{array}{c}\text { Sensitivity } \\
(\%)\end{array}$ & $\begin{array}{c}\text { Specificity } \\
(\%)\end{array}$ \\
\hline $\begin{array}{c}\text { Choice Reaction } \\
\text { Time - MRT }\end{array}$ & $.936, .879-.993$ & $<.001$ & $804.96 \mathrm{~ms}$ & 100 & 83 \\
$\begin{array}{c}\text { Choice Reaction } \\
\text { Time - TT }\end{array}$ & $.912, .843-.981$ & $<.001$ & $81.25 \mathrm{~s}$ & 100 & 78,7 \\
ILT - Seq 1 - MRT & $.906, .820-.993$ & $<.001$ & $751.04 \mathrm{~ms}$ & 86.7 & 70.2 \\
ILT - Seq 1 - TT & $.899, .806-.992$ & $<.001$ & $39.80 \mathrm{~s}$ & 86.7 & 74,5 \\
ILT - Seq 2 - MRT & $.939, .878-1.000$ & $<.001$ & $687.33 \mathrm{~ms}$ & 100 & 74,5 \\
ILT - Seq 2 - TT & $.945, .888-1.000$ & $<.001$ & $34.62 \mathrm{~s}$ & 100 & 78,7 \\
ILT - Seq 3 - MRT & $.932, .867-.997$ & $<.001$ & $655,77 \mathrm{~ms}$ & 93.3 & 70.2 \\
ILT - Seq 3 - TT & $.942, .882-1.000$ & $<.001$ & $33,25 \mathrm{~s}$ & 93,3 & 72.3 \\
ILT - Seq 4 - MRT & $.940, .878-1.000$ & $<.001$ & $640.70 \mathrm{~ms}$ & 100 & 70,2 \\
ILT - Seq 4 - TT & $.950, .891-1.000$ & $<.001$ & $33,17 \mathrm{~s}$ & 93,2 & 72.3
\end{tabular}




$\begin{array}{cccccc}\text { ILT - Seq 5 - MRT } & .919, .844-.994 & <.001 & 671.35 \mathrm{~ms} & 86.7 & 70.2 \\ \text { ILT - Seq 5 - TT } & .915, .835-995 & <.001 & 32.88 \mathrm{~s} & 86,7 & 70,2 \\ \text { VSTM - MRT D } & .833, .728-.938 & <.001 & 675.00 \mathrm{~ms} & 86.7 & 70.2 \\ \text { FRM - MRT } & .835, .713-.958 & <.001 & 1593.29 \mathrm{~ms} & 80 & 70.2 \\ \text { FRM - TT } & .821, .702-.941 & <.001 & 76.90 \mathrm{~s} & 73.3 & 70.2 \\ \text { FRM - BL2 - MRT } & .813, .687-.939 & <.001 & 1543.03 \mathrm{~ms} & 73.3 & 70.2 \\ \begin{array}{c}\text { FRM - BL3 -MRT } \\ \text { FRM - Tardio - }\end{array} & .871, .769-.973 & <.001 & 1455.73 \mathrm{~ms} & 86.7 & 70,2 \\ \quad \text { MRT } & .828,707-.950 & <.001 & 1533.70 \mathrm{~ms} & 80 & 70.2 \\ \begin{array}{c}\text { STROOP - BL1 - } \\ \text { MRT }\end{array} & .882, .799-.966 & <.001 & 853.78 \mathrm{~ms} & 93.3 & 70.2 \\ \begin{array}{c}\text { STROOP - BL3 - } \\ \text { MRT }\end{array} & .824, .713-.935 & <.001 & 1155.60 \mathrm{~ms} & 73.3 & 70.2 \\ \quad \begin{array}{c}\text { SUR - TT } \\ \text { I }\end{array} & .834, .716-.952 & <.001 & 128.38 \mathrm{~s} & 73.3 & 70.2\end{array}$

ms: millisseconds; s: seconds; MRT: Median Reaction Time; TT: Total Time; ILT: Implicit Learning Test; Seq: Sequence; VSTM: Visuospatial Short-Term Memory; FRM: Face Recognition and Memory; Stroop: Stroop Test; SUR: Survey.

It was demonstrated that, in general, time variables, like choice reaction time and total time, were good to discriminate the sample of healthy subjects from the sample of people with PD, mainly in tasks of choice of stimulus, implicit learning, visuospatial memory, memory and recognition of faces and inhibitory control.

The ROC curves (Figures 1, 2, 3 and 4) are presented below for PD versus CG.

Figure 1. ROC Curve - sensibility and specificity for Choice Reaction Time Median Reaction Time and Total Time for PD versus CG. 


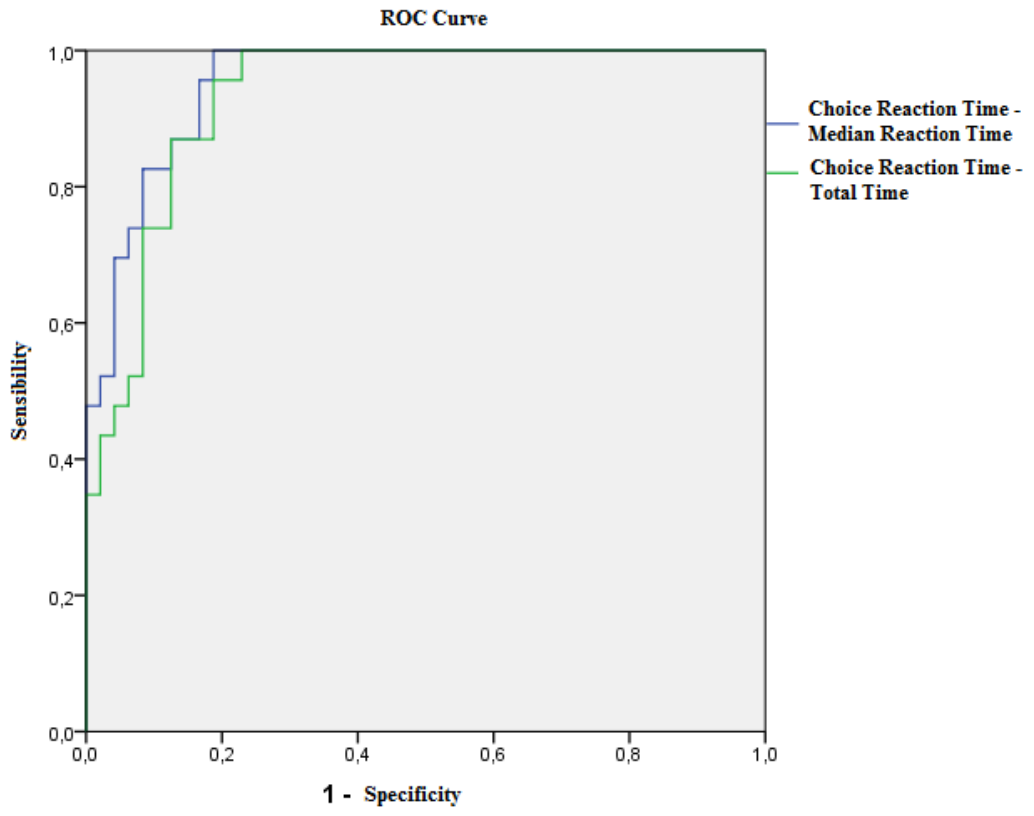

Figure 2. ROC Curve - sensibility and specificity for Implicit Learning Test Median Reaction Time and Total Time for PD versus CG.

ROC Curve

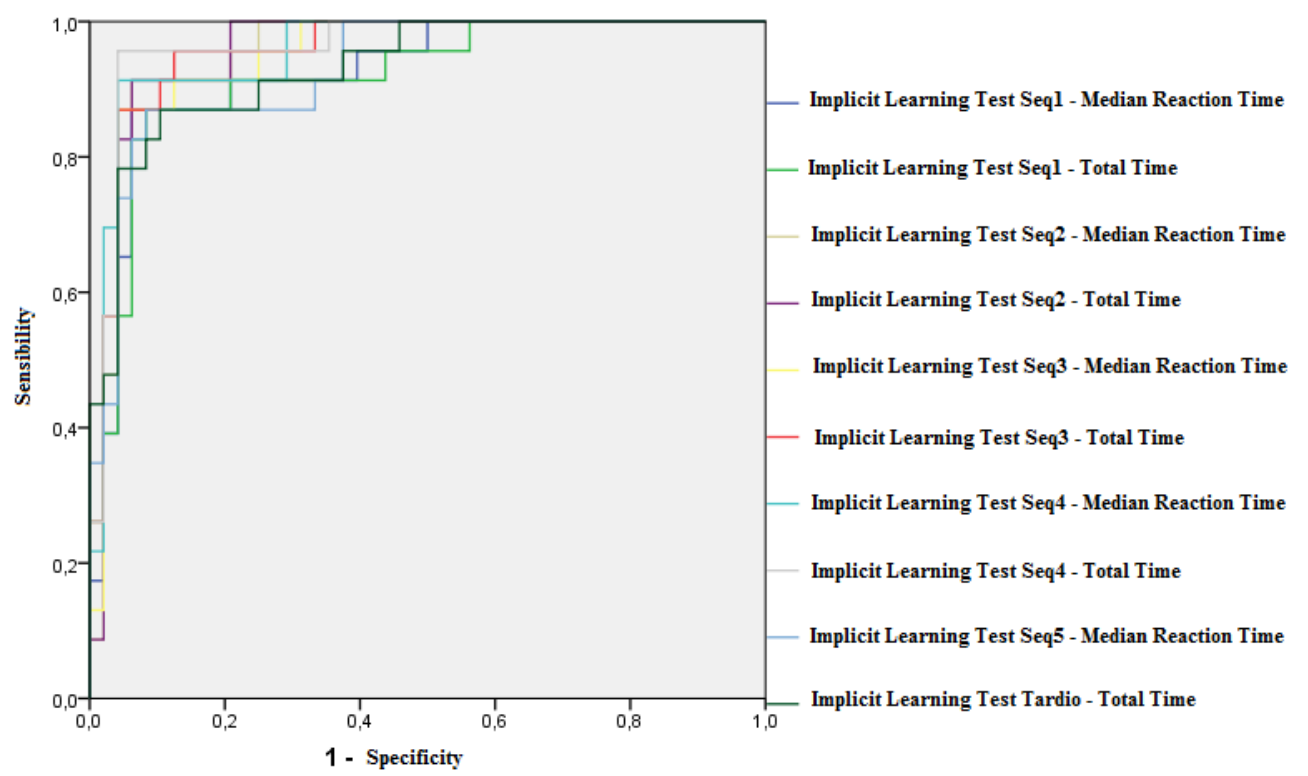

Figure 3. ROC Curve - sensibility and specificity for Visuospatial Short-Term Memory, Stroop Test and Survey Median Reaction Time and Total Time for PD versus CG. 


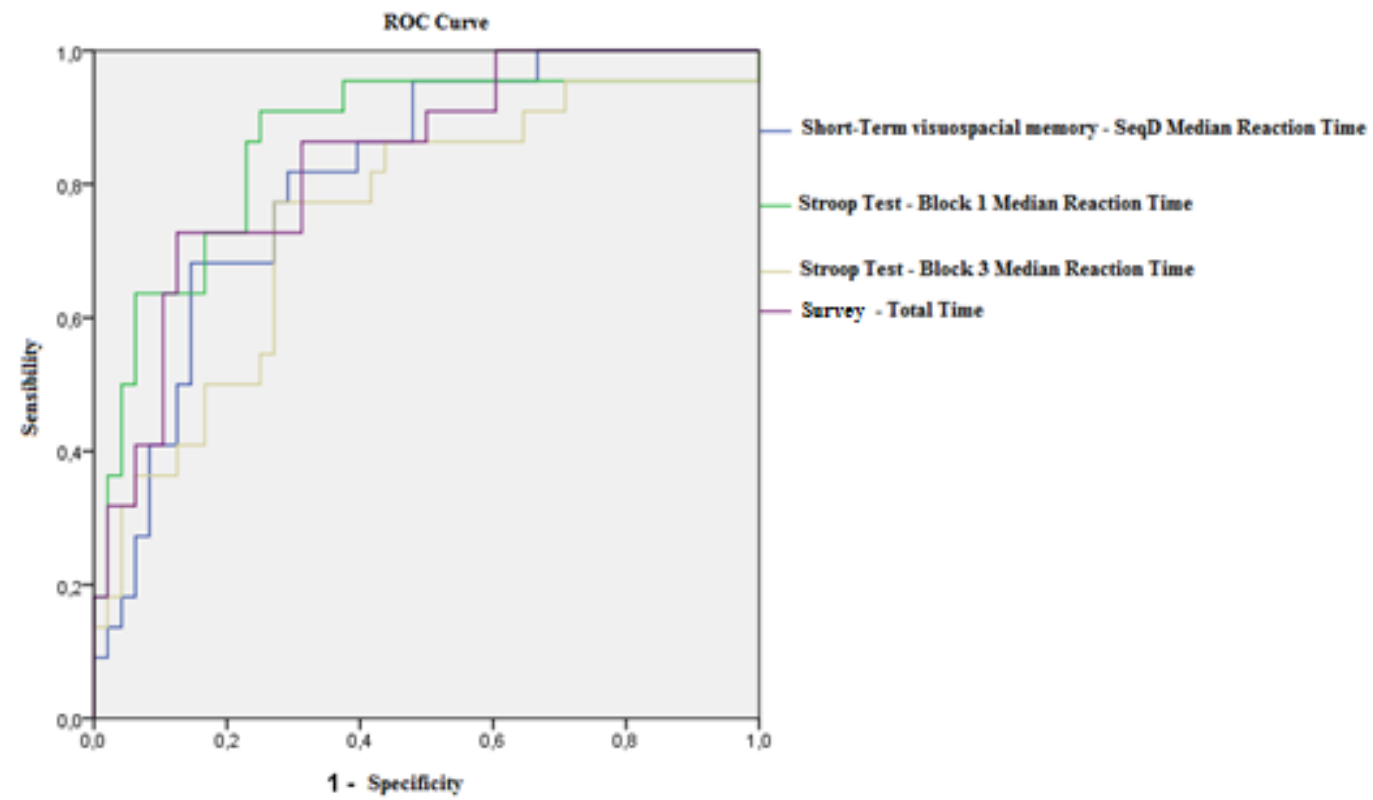

Figure 4. ROC Curve - sensibility and specificity for Face Recognition and Memory Median Reaction Time and Total Time for PD versus CG.

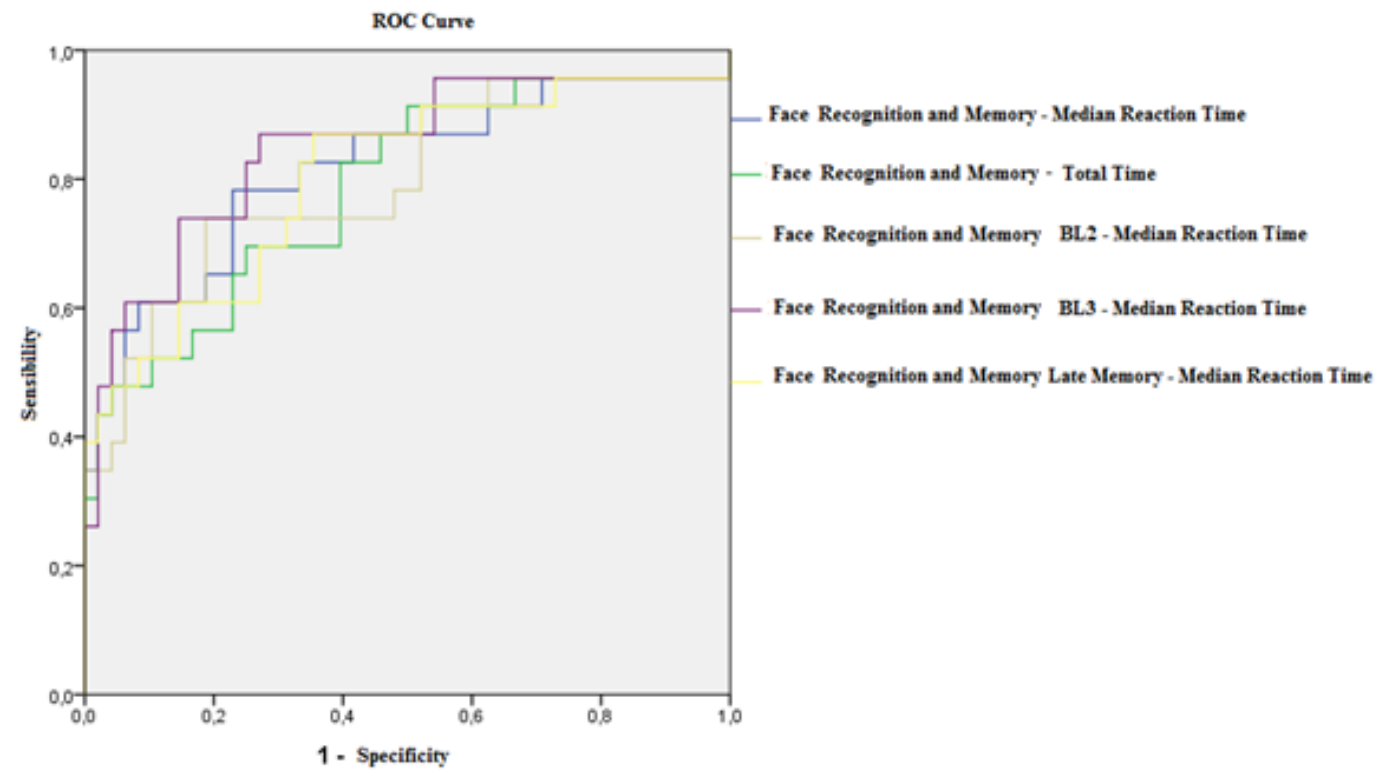

The Foward method was used during logistic regression analysis because we're looking for a simple model with as few variables as possible to promote faster tracking. The final model included 4 variables: Choice Reaction Time Median Reaction Time, Implicit Learning Test - First Sequence Reaction Time, Implicit Learning Test - Fourth Sequence Total Time and Stroop Test - Block 2 Median Reaction Time. This model correctly classified 100\% of cases, with $100 \%$ of specificity and $100 \%$ sensitivity. The final model had a chi-square value of 
87.15 (4), $\mathrm{p}<. .001$. The -2 Log likelihood was <.001, with Cox \& Snell R Square of 0.712 and 1.000 Nagelkerke R Square.

\section{DISCUSSION}

The screening of the patient's cognitive functioning is usually performed in studies to characterize the sample and identify the compromises to be analyzed. However, comparing cognitive data from different populations and using different tests generates conflicts in the literature, mainly because they use screening instruments that do not have the sensitivity to detail cognitive functioning sufficiently (Heluani, 2014). The batteries of computerized tests have been applied in several clinical populations, helping in diagnoses, drug and psychoeducative interventions. These evidences corroborate the relevance regarding the validation of computerized batteries benefiting from the new technologies applied to Psychology.

PD patients without dementia have impaired verbal comprehension, the identification of grammatically complex sentences, repetitive speech, decreased capacity for abstraction, slow processing speed and deficit in attention (Melo, Barbosa \& Carameli, 2007). Regarding the processing speed, the slowing down of decision-making processes is a cognitive alteration that can arise early in the evolution of $\mathrm{PD}$, without representing the installation of a dementia. This progressive decrease in processing is already expected over the years, being enhanced with the disease.

Memory impairment for non-verbal content, which is usually greater than for verbal content, is also present. In this regard, the difficulties in slowing down mental processing could corroborate the difficulty presented by the patient in nonverbal memory - represented here by the repetition of the 5 sequences of white squares arranged on the screen. PD patients show normal performance in several measures of explicit memory and recognition. CompCog was able to discriminate the performance of the two samples in these aspects.

Visual perception is divided into discriminative capacity (ability to analyze a new stimulus) and ability to recognize (ability to identify a familiar visual stimulus). The visual recognition task requires preserved memory for previously learned visual information and accurate visual perception for interpretation. Visual recognition is preserved in patients with PD. What was discriminated by 
the computerized battery was not the successes or errors, but the difference in time for this identification and recognition. Parkinsonian patients also have difficulty in identifying specific figures involved in more complex patterns, which can be associated with the third task of Stroop, which in addition to attention also requires inhibitory control.

Levodopa acts on some aspects of cognition, such as flexibility and working memory without beneficial changes in other functions, such as visuospatial recognition, verbal ability or associative learning. Knowing this, it is necessary to emphasize that the executive function can worsen in the OFF phase, so it is the use of levodopa that is extremely important to occur before the neuropsychological assessment (Svenningsson et al, 2012; Yang et al, 2016) which did not happen in all cases.

There are several advantages of using this computerized battery: the dynamic and colorful interface, the possibility of more accurately measuring response times discreetly throughout the evaluation process; control the time and order of presentation of stimuli; record latencies and response types; develop several forms of the same test; reduce financial costs by reducing the use of paper; reduce the examiner's effects and provide automatic performance correction, restricting the possibility of errors by the examiner (Cernich et al, 2007; Charchat et al, 2001; Schatz and Browndyke, 2002). Once explained and/or read, hardly any doubt or difficulty was presented by the subjects. Patients with visual difficulties could see the stimuli well, people with low education and/or who were not used to using technology were able to understand and respond to commands.

Other important issues are: the most standardized application format for computerized instruments; faster corrections, test scores and results are obtained, almost immediately (Ritsner et al, 2006). Allied to this, they reduce the time of administration and training of professionals when compared to traditional tests (Wild et al, 2008). What seems to stand out the most is the greater sensitivity to detect cognitive changes (Mattos, 1998; Wild et al, 2008). Among these measures, specific and complex variables stand out, such as reaction time (RT) in milliseconds. According to Charchat et al (2001), RT is a measure that allows a more detailed and refined assessment of cognitive functioning, as seen in that study. 
It is interesting to think about why other variables did not differ. First, this sample had a very small number of participants due to difficulties already clarified in the methodology. A more robust sample would be needed to carry out a more forceful analysis. In addition, successes and errors were not enough to distinguish the stages, but rather time variables - be it the average reaction or the total completion of the task. That is, it is not enough to know the patient's final score to infer something about his performance, but it tells us much more how long it took him to react to the stimulus and to finish the task. PD patients constantly complain of generalized slowness, causing a longer delay to perform the usual tasks.

And in this way, we perceive the great contribution of the clinical validation of this instrument to this population, which has an impacting aspect on the time spent performing tasks, but which is not always considered in evaluations and, much less, measured. CompCog offers this measure for all subtests.

Some of the limitations of this study were that, despite being performed at the neurology outpatient clinic of a public hospital, the care for patients with PD was performed only one day a week - which prevented a much larger sample until the analysis was closed; for the same reason, all evaluations were performed by only one neuropsychologist, whereas if there were more space and days of attendance, simultaneous or alternate evaluations could be performed; despite being engaged, the patients were anxious for the neurologist's assistance and, sometimes, they did not completely disconnect from the outside; and the impossibility of increasing the sample due to not being able to recover the results of the patients evaluated at the end of the year.

For the future, the intention is to increase the samples to guarantee more reliable analyzes and more robust results. 


\section{REFERENCES}

Atalaia-Silva KC, Lourenço RA. Tradução, adaptação e validação de construto do Teste do Relógio aplicado entre idosos no Brasil. Revista de Saúde Pública, 2008, v. 42, n. 5, p. 930-937.

Cernich AN et al. Sources of error in computerized neuropsychological assessment. Archives of Clinical Neuropsychology, 2008, v. 22S, p. S39-S48.

Charchat, H. (1999). Desenvolvimento de uma bateria de testes neuropsicológicos computadorizados para o diagnóstico precoce da Doença de Alzheimer. Dissertação (Mestrado) não-publicada. Curso de Pós-Graduação de Neurociências e Comportamento, Instituto de Psicologia, Universidade de São Paulo. São Paulo, SP.

Charchat $\mathrm{H}$ et al. Investigação de Marcadores Clínicos dos Estágios Iniciais da Doença de Alzheimer com Testes Neuropsicológicos Computadorizados. Psicologia: Reflexão e Crítica, 2001; v. 14, n. 2, p. 305-316.

Fichman, HC et al. Age and educational level effects on the performance of normal elderly on category verbal fluency tasks. Dementia and Neuropsychologia. [online]. 2009, v.3, n.1, p.49-54.

Heluani AS. Cognição, humor e atividades funcionais em pacientes com doença de Parkinson submetidos à estimulação cerebral profunda bilateral em núcleo subtalâmico. 2014. Dissertação (mestrado) - Faculdade de Medicina, Universidade de São Paulo, 2014.

Hughes AJ, Daniel SE, Kilford L, Lees AJ. Accuracy of clinical diagnosis of idiopathic Parkinson's disease: a clinicopathological study of 100 cases. Journal of Neurology, Neurosurgery and Psychiatry, v. 55, n. 3, p. 181-184, 1992.

Johnson DR et al. Reliability and construct validity of the Automated Neuropsychological Assessment Metrics (ANAM) mood scale. Archives of Clinical Neuropsychology, 2008, v. 23, p. 73-85.

Litvan I et al. Diagnostic criteria for mild cognitive impairment in Parkinson's disease: Movement Disorder Society Task Force guidelines. Moviment Disorder, 2012, v. 27, n. 3, p. 349-356.

Mattos P. Uso de testes computadorizados em neuropsicologia. Em: Gagliardi RJ, Reimao R (Org.). Clínica Neurológica, São Paulo: Lemos, 1998, p. 319-322.

Melo LM, Barbosa ER, Caramelli, P. Declínio cognitivo e demência associados à doença de Parkinson: características clínicas e tratamento. Revista de Psiquiatria Clínica, 2007, v. 34, n. 4, p. 176-183.

Ritsner MS, Blumenkrantz H, Dubinsky T, Dwolatzky T. The detection of neurocognitive decline in schizophrenia using the Mindstreams Computerized Cognitive Test Battery. Schizophrenia Research, 2006, v. 82, p. 39-49. 
Schatz P, Browdyke J. Applications of Computer-based Neuropsychological Assessment. Journal of Head Trauma Rehabilitation, 2002, v. 17, n. 5, p. 395410.

Schneider JS, Sendek S, Yang C. Relationship between Motor, Cognitive, and Demographic Variables in PD. PLOS ONE, 2015, v. 10, n. 4.

Wild K, Howieson D, Webbe F, Seelye A, Kaye J. Status of computerized cognitive testing in aging: A systematic review. Alzheimer's \& Dementia, 2008, v. 4, p. $428-437$.

Woo H. Computerized Neuropsychological Assessments. CNS Spectrums, 2008, v. 13, n. 10 Suppl 16, p. 14-17. 
\begin{tabular}{|l|}
\hline ARTICLE 4 \\
Eduarda Naidel Barboza e Barbosa, Larissa Marques Francisco, Jose Augusto \\
Nasser dos Santos and Helenice Charchat Fichman, What cognitive functions \\
discriminate ON e OFF stages in people with Parkinson Disease after Subtalamic \\
Nucleos Deep Brain Stimulation. (in preparation)
\end{tabular}

\section{ABSTRACT}

Introduction: In addition to drug treatment, surgical intervention represents an alternative for some PD patients with motor deficits. The most common intervention is deep brain stimulation of the subthalamic nucleus (STN-DBS). It is extremely important to carry out a neuropsychological assessment in patients with STN-DBS, not only to identify losses related to the disease, but also to compare the influence on cognition in the pre and postoperative period. Objective: The objective of this study was to compare the cognitive profile of PD patients who underwent STN-DBS implantation surgery in the ON and OFF stages, that is, with the stimulus on and off to check if there is any influence of the stimulus on the performance of cognitive tasks. Method: Nine patients with PD and STNDBS were evaluated. Various instruments were used (Brief Cognitive Screening Battery that includes Mini Mental State Examination, Picture Memory Test, Clock Drawing Test and Animal Verbal Fluency Test, in addition to FAS Verbal Fluency Test, Verbal Rey Auditory Learning Test, Digits, Stroop Test, Visual Hooper Test Organization and Beck Depression Inventory) with the stimulation ON for the neuropsychological assessment and CompCog was used with the stimulation ON and OFF for comparison. Results: After analyzing the results of CompCog, a computerized neuropsychological battery, it was observed that time variables, such as reaction time of incidental and episodic memory and inhibitory control, were good for discriminating stages ON and OFF. In addition, CompCog showed a tendency to discriminate attention and processing speed reaction times and and total time in episodic memory. Conclusion: This discrete differentiation may be due to the small sample size, but provides data important factors to be considered in the search for discriminatory aspects at both stages and $\mathrm{m}$ PD patients with STN-DBS and perhaps PD with medication alone.

\section{Keywords}

Parkinson's Disease; Neuropsychological Assessment; Deep Brain Stimulation; CompCog 


\section{RESUMO}

Introdução: Além do tratamento medicamentoso, a intervenção cirúrgica representa uma alternativa para alguns pacientes com DP com déficits motores. A intervenção mais comum é a estimulação cerebral profunda do núcleo subtalâmico (STN-DBS). É extremamente importante a realização de uma avaliação neuropsicológica em pacientes com STN-DBS, não apenas para identificar perdas relacionadas à doença, mas também para comparar a influência na cognição no pré e pós-operatório. Objetivo: O objetivo deste estudo foi comparar o perfil cognitivo de 9 pacientes em DP submetidos à cirurgia de implantação de STNDBS nos estágios ON e OFF, ou seja, com o estímulo ligado e desligado para verificar se há alguma influência do estímulo no estímulo. desempenho nas tarefas propostas. Método: Foram avaliados 9 pacientes com DP e STN-DBS. Foram utilizados vários instrumentos (Bateria Breve de Rastreio Cognitivo que inclui Mini Exame do Estado Mental, Teste de Memória de Figuras, Teste de Desenho de Relógio e Teste de Fluência Verbal Animal, além de Teste de Fluência Verbal FAS, Teste de Aprendizagem Auditiva Verbal Rey, Dígitos, Teste de Stroop, Organização Visual Hooper Teste e Inventário de Depressão de Beck) com a estimulação ligada para a avaliação neuropsicológica e o CompCog foi usado com a estimulação ligada e desligada para comparação. Resultados: Após analisar os resultados do CompCog, uma bateria neuropsicológica computadorizada, observou-se que variáveis de tempo, como tempo de reação da memória incidental e episódica e controle inibitório, eram boas para discriminar os estágios $\mathrm{ON}$ e OFF. Além disso, o CompCog mostrou uma tendência a discriminar os tempos de reação da atenção e da velocidade de processamento e o tempo total na memória episódica. Conclusão: Essa diferenciação discreta pode ser devida ao pequeno tamanho da amostra, mas fornece dados importantes a serem considerados na busca de aspectos discriminatórios em ambos os estágios em pacientes com DP com STN-DBS e, talvez, com DP apenas com medicação.

\section{Palavras-Chave}

Doença de Parkinson; Avaliação Neuropsicológica; Estimulação Cerebral Profunda; CompCog 


\section{What cognitive functions discriminate ON e OFF stages in people with Parkinson Disease after Subtalamic Nucleos Deep Brain Stimulation.}

One of the most aggressive non-motor symptoms of Parkinson Disease (PD) is cognitive impairment, which occurs more quickly in attentional and visuospatial functions, as well as executive functions and skill learning (implicit) (Wang, 2018). In the early stages of the disease, cognitive impairment was found in memory (20\%), in addition to executive functions (30\%) and global cognitive functioning (50\%) (Muslimovic et al, 2005). In the systematic review conducted by Barbosa and Charchat-Fichman (2019b) was demonstrated that the global cognitive functioning is quite assessed, as well as different aspects of executive functions and memory.

It is difficult to correlate neuropathology with cognitive decline in PD, but studies show that impairment of executive functions, visuospatial skills and global functioning are related to the APOE4 allele (Ding et al, 2015). Vasconcellos et al (2017) found structural abnormalities by observing MRI of both people with PD and controls with mild cognitive impairement (MCI) and attention, memory and executive function impairment were the functions more severe in amnestic PDMCI group. In cases in which PD is associated with MCI, partial atrophy of the partial gray matter is observed in the frontal, temporal and parietal cortices, as well as in the regions of the hippocampus, amygdala and putamen. When compared with PD patients without MCI, they have significantly depleted performance in virtually all cognitive domains: executive functions, attention, memory and language (Ding et al, 2015). Deficits in executive funtions are the result of a change in dopaminergic transmission and visuospatial, language and memory deficits are the result of a change in cholinergic transmission.

The clinical presentation of PD is (motor symptoms) with rest tremor, stiffness, bradykinesia and postural instability, hypomimia, decreased eye blinking and hypophonia, micrograph, sialorrhea (non-motor symptoms) gastrointestinal, urinary and sexual disorders, sleep disorders and respiratory disorders and neuropsychiatric disorders, including cognitive deficits. The ON 
and OFF stages appear in the intermediate stage of PD (between 3 and 5 years of the disease) and are related to the effect of the medication: at ON stage there is an improvement in parkinsonian symptoms and at OFF stage they reappear (Cardoso, 1995; de Paixão et al, 2016). After taking a dose of the medicine, the patient usually feels his symptoms controlled or ceased. With the end of the dose effect, the symptoms are noticed again. The amount of medication taken by patients with PD is around 5 or 4 doses a day.

Fifty-four por cent of PD patients do not adhere to drug treatment because forget and/or confuse the dose, the hour or even taking an extra dose. These difficulties affect the patient's clinical evolution and quality of life (Marchi et al, 2011). Over time, this maintenance becomes more and more complicated, with ON periods being shorter and needing medication replacement earlier and earlier.

Deep Brain Stimulation (DBS) consists in the application of low intensity electric current, generally high frequency and variable pulse width continuously or by intermittent cycles to previous selected nervous structures inside the brain. This neuromodulation relieves symptoms of various diseases, according to the target of the electrodes. In the case of PD, the targets are the subthalamic nuclei or globuspallidus (GPi) for motor symptoms control, effects on cognition - for example - may occur. While some studies show improvement in cognitive functions after DBS (Aguilar, Soto and Esguerra, 2011; Asahi et al, 2014; Vonberg et al, 2016), in visual working memory (Ventre-Dominey et al, 2016), in decision making (Boller et al, 2014), in executive functions (Pham et al, 2015), verbal memory (Tang et al, 2015). In others, the opposite effect is found, that is, worsening cognitive functions (Krishnan et al, 2016), verbal fluency (Houvenaghel et al, 2015; Tang et al, 2015). Massano \& Garrett, (2012), Yilmaz et al (2015) and Tremblay et al (2015) did not observe changes in the assessed functions, in the understanding of metaphor and verbal fluency/visuospatial orientation, respectively. In assessing mood, anxiety levels decreased in Tang et al (2015) and Pham et al (2015) and that of apathy increased in Houvenaghel et al (2015).

The literature points to an evident motor and quality of life improvement after DBS in patients with PD, however studies dedicated to the investigation of 
the relationship between DBS-STN and cognitive functioning are controversial, making further studies investigating this relationship necessary. Cognitive decline in PD is associated with an increased risk of developing dementia and affecting the functionality of patients, as well as promoting an increase in psychiatric comorbidities (Campos et al, 2014). In this context, the investigation of the cognitive effects of STN-DBS in PD becomes essential and here we are using, besides conventional neuropsychological battery to evaluate the neuropsychological patients profile, a neuropsychological computerized battery to promote more accurate information.

\section{METHODOLOGY}

\section{Sample}

The sample consisted of patients from a private clinic in Rio de Janeiro city, Neuroclínica, by neurosurgeon José Augusto Nasser dos Santos. Nine patients with PD diagnosis and STN-DBS were evaluated. The gold standard adopted was the diagnosis of PD performed by the neurosurgeon. Some of the criteria required for the diagnosis of PD, according to the UK PD Brain Society Bank (Litvan et al, 2009), are bradykinesia and at least one of the following symptoms: muscle stiffness, tremor at rest (clinically assessed) and non postural instability caused by vestibular, cerebellar or proprioceptive visual disturbances.

The patients were selected by the neurosurgeon for having already undergone implantation surgery. Patients who are selected for surgery are those with disabling motor complications. In addition, having been diagnosed with PD for at least 5 years, have a good response to levodopa and none or very mild cognitive impairment and absence of psychiatric or controlled disease - including dementia. Twenty-six patients referred by the neurosurgeon were evaluated, however not all met the inclusion criteria for this study, some were afraid to turn off the device $(n=3)$, even in the presence of the physician, some would still have the surgery and the evaluation had another objective $(n=6)$, there was still a problem with the computerized neuropsychological battery that prevented access to the data of some patients $(n=4)$ and some had complications that impaired the assessment, whether motor or cognitive $(n=4)$. 
The patients were referred by the neuropsychologist, which performed a screening with an evaluation protocol established. The inclusion criteria to participate in the study was: a) be a patient selected by the neurosurgeon with PD diagnosis and STN-DBS and be over than 45 years of age. Were excluded patients a) presenting serious systemic diseases (hormonal, brain disorders, among others that can cause cognitive decline) b) a recent history of alcohol or other drug dependence, c) use of psychotropics that affect cognition, such as benzodiazepines, d) existence of cardiovascular diseases, hypertension and diabetes no controlled, e) visual and/or hearing disorders without correction; f) presence of current or previous neurological diseases and g) fulfill dementia criteria, based on the clinical evaluation of the physician.

\section{Ethical aspects}

This study was approved by the Research Ethics Committees of the Catholic Pontifical University (21/2019). People participated in this research by signing a term of informed consent, according to Resolution 466/12 of the National Health Council, which deals with the guidelines and standards for research involving humans.

\section{Instruments}

The following instruments were applied with the stimulation $\mathrm{ON}$ for establishing a neuropsychological profile: a) structured interview (with questions regarding clinical and socio-demographic aspects), b) CompCog - IPad version (Table 1) and c) Brief Cognitive Screening Battery that includes the following tests: Mini-Mental State Examination (MMSE), Figure Memory Tests (FMT), Clock Drawing Test (TDR), Animal Verbal Fluency Test (AVFT) and FAS Verbal Fluency Test (FAS), Rey Auditory Verbal Learning Test (RVALT), Digits, Stroop Test (Stroop), Visual Hooper Organization Test (Hooper) and Beck Depression Inventory (BDI). CompCog was applied with stimulation OFF to compare cognitive performance on both stages (table 1). 
Table 1. CompCog subtests, variables and description

\begin{tabular}{|c|c|c|}
\hline Subtests & Variables & Description \\
\hline $\begin{array}{c}\text { Simple Reaction } \\
\text { Time }\end{array}$ & Median reaction time & $\begin{array}{l}\text { There is a white rectangle at the } \\
\text { bottom of the screen. As soon as a } \\
\text { white square appears in the middle } \\
\text { of the screen, the person should } \\
\text { touch the rectangle. }\end{array}$ \\
\hline $\begin{array}{c}\text { Choice Reaction } \\
\text { Time }\end{array}$ & $\begin{array}{l}\text { Median reaction time, } \\
\text { correct answers and } \\
\text { revised median reaction } \\
\text { time (choice reaction time } \\
\text { - simple reaction time) })^{*}\end{array}$ & $\begin{array}{l}\text { There are two rectangles, a white } \\
\text { and an orange one, at the bottom of } \\
\text { the screen. As a white or orange } \\
\text { square appears in the middle of the } \\
\text { screen, the person should touch the } \\
\text { rectangle of the same color. }\end{array}$ \\
\hline $\begin{array}{l}\text { Implicit Learning } \\
\text { Test }\end{array}$ & $\begin{array}{l}\text { Median reaction time in } \\
\text { each of five tasks and } \\
\text { implicit learning (median } \\
\text { reaction time in sequence } \\
4-\text { median reaction time } \\
\text { in sequence } 1)^{*}\end{array}$ & $\begin{array}{l}\text { There are } 10 \text { grey squares } \\
\text { distributed on the screen. One } \\
\text { square becomes white at a time and, } \\
\text { as the person touches it, another } \\
\text { one lights up. There is a fixed } \\
\text { sequence of } 25 \text { squares that is } \\
\text { repeated } 4 \text { times and one last } \\
\text { random sequence of also } 25 \\
\text { squares. The difference between } \\
\text { reactions of subsequent sequences } \\
\text { are used as an implicit learning } \\
\text { measure. }\end{array}$ \\
\hline $\begin{array}{l}\text { Visual and Spatial } \\
\text { Short-Term } \\
\text { Memory }\end{array}$ & $\begin{array}{l}\text { Correct answers, direct } \\
\text { order SPAN, reaction time } \\
\text { in direct order, inverse } \\
\text { order SPAN and reaction } \\
\text { time in direct order }\end{array}$ & $\begin{array}{l}\text { There are, as there were in the last } \\
\text { test, } 10 \text { grey squares distributed on } \\
\text { the screen. One will become white at } \\
\text { a time, making a sequence that must } \\
\text { be reproduced. The sequence } \\
\text { increases in number if the person } \\
\text { gets two of four attempts right. The } \\
\text { test starts with a message stating } \\
\text { the type of sequence - first forward } \\
\text { and then reverse - and the number } \\
\text { of squares that will appear in } \\
\text { sequence - from } 2 \text { to } 8 \text {. When the } \\
\text { forward sequences end, the reverse } \\
\text { sequences starts. Results are } \\
\text { measured by the span reached. }\end{array}$ \\
\hline $\begin{array}{l}\text { Face Recognition } \\
\text { and Memory }\end{array}$ & $\begin{array}{l}\text { Correct answers and } \\
\text { median reaction time for } \\
\text { each of the four tasks }\end{array}$ & $\begin{array}{l}\text { At first, } 10 \text { drawings of unknown } \\
\text { faces are presented for } 30 \text { seconds } \\
\text { on the screen with the instruction for } \\
\text { memorizing the faces. After that the } \\
\text { person should choose between } 10 \\
\text { pairs of faces which one was among } \\
\text { those initially shown for } \\
\text { memorization. The task is repeated } \\
\text { three times in a row and again after } \\
20 \text { minutes. }\end{array}$ \\
\hline $\begin{array}{c}\text { Inhibitory Control } \\
\text { Test }\end{array}$ & $\begin{array}{l}\text { Median reaction time, } \\
\text { correct answers, correct } \\
\text { answers median reaction }\end{array}$ & $\begin{array}{l}\text { Squares of different colors will } \\
\text { appear in the middle of the screen } \\
\text { for one second each, the white ones }\end{array}$ \\
\hline
\end{tabular}




\begin{tabular}{|c|c|c|}
\hline & $\begin{array}{l}\text { time, errors median } \\
\text { reaction time and errors }\end{array}$ & should be avoided. \\
\hline Stroop Test & $\begin{array}{l}\text { Interference, median } \\
\text { reaction time and errors } \\
\text { for each of the three } \\
\text { tasks }\end{array}$ & $\begin{array}{l}\text { This test includes three tasks, like } \\
\text { the original Stroop paradigm. All } \\
\text { tasks have } 4 \text { rectangles (green, } \\
\text { red, blue and yellow) located at the } \\
\text { bottom of the screen. The person } \\
\text { should touch the one matching the } \\
\text { stimuli (first: a colored square, } \\
\text { second: fruit names written in } \\
\text { different colors than the actual } \\
\text { color of the fruit, and third: color } \\
\text { names that are written in another } \\
\text { color) that appears in the middle of } \\
\text { the screen considering its color. }\end{array}$ \\
\hline Survey Test & $\begin{array}{l}\text { Median reaction time, } \\
\text { correct answers, } \\
\text { reaction time of correct } \\
\text { answers, errors and } \\
\text { reaction time of errors } \\
\text { for each of the three } \\
\text { tasks }\end{array}$ & $\begin{array}{l}\text { Squares of different colors will } \\
\text { appear in the middle of the screen } \\
\text { for one second each. Results are } \\
\text { measured by reaction time and the } \\
\text { percentage of errors and correct } \\
\text { answers. }\end{array}$ \\
\hline
\end{tabular}

* possible variables to be calculated

\section{Procedures}

Two evaluations were performed on the same day: one with stimulation on, ON stage, comprising CompCog and the conventional tests (pencil and paper) and, then, with stimulation off, OFF stage, comprising only CompCog subtests. The duration of the CompCog tasks takes between half an hour and an hour, depending on the degree of motor or cognitive difficulty of the patient. In addition, the evaluations with the stimulation off were performed with the subject under the effect of levodopa, as it would be impracticable to carry out the tests without the medication. The neuropsychologist herself, previously trained to do so, turned off the device and turned it back on as needed. The assessments took place in the responsible neurosurgeon clinic Neuroclínica.

\section{Data Analysis}

Comparisons between means of demographic, clinical profile data and CompCog subtests results were performed through the t-test or chi-square test. In addition, the non-parametric test Wilcoxon 2 related samples, were used to 
compare the performances of each subject in attention, processing speed, implicit learning, episodic and working memory and inhibitory control, checking if there are significant differences between their results in the two stages, ON and OFF. Cognitive data did not presented a normal distribution, so the non-parametric test were used.

These data analysis were performed with the aid of statistical software Statistical Package for Social Sciences (SPSS) version 22.0. For all analysis the value of significance was set at $\mathrm{p}<0.05$.

\section{RESULTS}

The mean age of PD patients with STN-DBS was 60,56 $( \pm 10.13)$ years and $12( \pm 5.45)$ years of schooling. Table 2 shows patients social and clinical caractherists and table 3 shows the neuropsychological profile of the sample with the stimulation $\mathrm{ON}$.

Table 2. Patients social and clinical caractheristics

\begin{tabular}{|c|c|c|c|c|c|}
\hline Patients & Age & Schooling & Profession & Comorbidities & Medication \\
\hline WMS & 60 & 5 & Merchant & High pressure & $\begin{array}{c}\text { "for high } \\
\text { pressure" name } \\
\text { not informed* }\end{array}$ \\
\hline HSB & 79 & 14 & Legal analyst & - & $\begin{array}{l}\text { Prolopa, Sifrol } \\
\text { and Entacapona }\end{array}$ \\
\hline SLGS & 52 & 15 & Physiotherapist & Diabetes & $\begin{array}{l}\text { Prolopa, Akington } \\
\text { and Glifage }\end{array}$ \\
\hline AOCS & 62 & 11 & Militar & - & $\begin{array}{l}\text { Prolopa, Azilet } \\
\text { and Contan }\end{array}$ \\
\hline ESG & 67 & 15 & Lawyer & - & $\begin{array}{l}\text { Levodopa, Sifrol, } \\
\text { Niar and Aztec }\end{array}$ \\
\hline VHSM & 44 & 22 & $\begin{array}{l}\text { Physician and e } \\
\text { acupuncturist }\end{array}$ & High pressure & $\begin{array}{l}\text { Levodopa + } \\
\text { Carbidopa, } \\
\text { Amantatina, } \\
\text { Rasagilina and } \\
\text { Rotigotina }\end{array}$ \\
\hline MSMO & 53 & 11 & Merchant & High pressure & $\begin{array}{l}\text { Prolopa and } \\
\text { Conversyl Plus }\end{array}$ \\
\hline APM & 66 & 4 & Seller & $\begin{array}{l}\text { High pressure } \\
\text { and arthrosis }\end{array}$ & $\begin{array}{c}\text { Prolopa, } \\
\text { Rasagilina, } \\
\text { Pinazan, Zytiga, } \\
\text { Predinisona and }\end{array}$ \\
\hline
\end{tabular}


Natrilix

$\begin{array}{llllll}\text { RFJ } & 62 & 11 & \text { Public agent } & - & \text { Prolopa and }\end{array}$ Jumexil

* does not use any PD medication because he maintains the habit of drinking alcohol

Table 3. Patients neuropsychological profile on ON stage

\begin{tabular}{|c|c|c|}
\hline Tests & Results (n=9) & Cut-off points \\
\hline MMSE & $25,89( \pm 2,85)$ & $\begin{array}{c}1 \text { to } 4 \text { y schooling - } 24,8 \\
\text { Brucki et al (2003) }\end{array}$ \\
\hline $\begin{array}{r}\text { MFT } \\
\text { (Nomination) } \\
\text { (Incidental Memory) } \\
\text { (Immediate Memory 1) } \\
\text { (Immediate Memory 2) } \\
\text { (Late Memory) } \\
\text { (Recognition) }\end{array}$ & $\begin{array}{c}10,00(0) \\
6,33( \pm 1,73) \\
7,00( \pm 2,06) \\
7,67( \pm 1,66) \\
6,88( \pm 2,03) \\
9,78( \pm 0,67)\end{array}$ & $\begin{array}{c}\quad<10 \\
\leq 7 \\
\leq 7 \\
\leq 7 \\
\leq 5 \\
\leq 7\end{array}$ \\
\hline Animals FVT & $16,11( \pm 6,05)$ & $\begin{array}{l}1 \text { to } 4 \text { y schooling }-10,73 \\
\text { (Silva et al, 2011) }\end{array}$ \\
\hline FAS FVT & $25.78( \pm 14.21)$ & \\
\hline Clock Drawing Test & $5.89( \pm 1.83)$ & $\begin{array}{l}\leq 9 \\
\text { (Sunderland et al, 1989; } \\
\text { Fichman et al, 2013) }\end{array}$ \\
\hline $\begin{array}{r}\text { RAVLT } \\
\text { (Learning A1A5) } \\
\text { Interference A6 } \\
\text { Late Memory A7 } \\
\text { Forgetting Speed } \\
\text { Proactive Interference } \\
\text { Retroactive Interference }\end{array}$ & $\begin{array}{c}37( \pm 14.20) \\
4.44( \pm 3.00) \\
4.56( \pm 3.94) \\
1.05( \pm 0.91) \\
0.867( \pm 0.388) \\
0.396( \pm 0.228)\end{array}$ & $\begin{array}{c}45.7( \pm 9.7) \\
9.4( \pm 3.1) \\
9.5( \pm 3.2) \\
1.02( \pm 0.19) \\
0.82( \pm 0.29) \\
0.82( \pm 0.19) \\
\text { (de Paula and Malloy- } \\
\text { Diniz, 2018) }\end{array}$ \\
\hline Digit Span & $11.11( \pm 3.33)$ & $\begin{array}{c}\text { (Wechsler, 1997; } \\
\text { Nascimento, 2005) }\end{array}$ \\
\hline $\begin{array}{r}\text { Stroop } \\
\text { Stroop 1 } \\
\text { Stroop 2 } \\
\text { Stroop 3 } \\
\text { Stroop Effect }\end{array}$ & $\begin{array}{c}20( \pm 8.0) \\
22.44( \pm 11.24) \\
45.63( \pm 13.63) \\
2.37( \pm 0.63)\end{array}$ & \\
\hline Hooper & $18.28( \pm 7.18)$ & $\begin{array}{l}10 \text { to } 19 \text { - moderate } \\
\text { (Malak et al, 2016) }\end{array}$ \\
\hline $\begin{array}{l}\text { Beck Depression } \\
\text { Inventory }\end{array}$ & $9.00( \pm 5.90)$ & $\begin{array}{c}0 \text { to } 11-\text { minimum } \\
\text { symptoms } \\
\text { (Cunha, 2001) }\end{array}$ \\
\hline
\end{tabular}

The patients had an average performance of $25.89( \pm 2.85)$ in the MMSE, which, as suggested by Brucki et al (2003), is a result higher than expected for 
subjects with schooling between 1 and 4 years (the lowest level of education was 4 years), both for the hospital and home context. There is no specific cutoff point for this group. It indicates preserved cognitive functioning in temporal and spatial orientation, attention and calculation, memory, language and constructive skills. In FMT, incidental and immediate memory were the ones impaired (Nitrini, 1994). The Animals FVT was generally preserved, while the CDT was compromised with concentrated numbers (Sunderland et al, 1989; Fichman et al, 2013). Regarding the BDI, it presented a minimum degree of depression (Cunha, 2001).

All patients had PD diagnosed for more than 5 years, had the electrodes implanted in the STN and Medtronic programmer and were evaluated in 2016.

Wilcoxon pairing was performed between the CompCog variables in the $\mathrm{ON}$ and OFF stages of PD patients. The variables with $\mathrm{p}<0.05$ were considered and it was observed the following variables showing significantly difference between both stages: ON Face Recognition and Memory - Late MRT from OFF Face Recognition and Memory - Late MRT ( $\mathrm{z}=-2.310, \mathrm{p}=.021, \mathrm{r}=-.77)$, ON Face Recognition and Memory - first block MRT from OFF Face Recognition and Memory - first block MRT ( $\mathrm{z}=-2.666, \mathrm{p}=.008, \mathrm{r}=-.889)$, ON Stroop Test third block MRT from OFF Stroop Test third block MRT ( $\mathrm{z}=-2.666, \mathrm{p}=.008, \mathrm{r}=-.889$ ).

However, other variables showed a tendency for significantly difference between both stages: ON Face Recognition and Memory TT from OFF Face Recognition and Memory TT ( $\mathrm{z}=-1.955, \mathrm{p}=.051, \mathrm{r}=-.652)$, ON Choice Reaction Time TT from OFF Choice Reaction Time TT $(\mathrm{z}=-1.955, \mathrm{p}=.051, \mathrm{r}=.652)$ and ON Stroop Test first block MRT from OFF Stroop Test first block MRT (z=-1.955, $\mathrm{p}=.051, \mathrm{r}=-.652)$.

Table 4. Comparison of CompCog results of both stages

\begin{tabular}{rrcc}
\hline \multirow{2}{*}{ Patients } & Subtests & ON & OFF \\
& Choice Reaction Time TT* & $103,2638 \mathrm{~s}$ & $121,3631 \mathrm{~s}$ \\
\multirow{2}{*}{ WMS } & Face Recognition and Memory TT* & $94,6501 \mathrm{~s}$ & $87,7447 \mathrm{~s}$ \\
& Face Recognition and Memory - Late MRT & $2119,067 \mathrm{~ms}$ & $1911,333 \mathrm{~ms}$ \\
& Face Recognition and Memory - 1b MRT & $2712,8810 \mathrm{~ms}$ & $2037,6580 \mathrm{~ms}$ \\
& Stroop Test 1b MRT* & $1236,8320 \mathrm{~ms}$ & $1269,325 \mathrm{~ms}$ \\
& Stroop Test 3b MRT & $2665,771 \mathrm{~ms}$ & $1365,562 \mathrm{~ms}$ \\
\hline
\end{tabular}


HSB

SLGS

AOCS

ESG

MSMO

APM

RFJ

Choice Reaction Time TT* Face Recognition and Memory TT* Face Recognition and Memory - Late MRT Face Recognition and Memory - 1b MRT Stroop Test $1 \mathrm{~b} \mathrm{MRT}^{\star}$ Stroop Test 3b MRT

Face Recognition and Memory TT*

Face Recognition and Memory - Late MRT

Face Recognition and Memory - 1b MRT

Stroop Test $1 \mathrm{~b} M \mathrm{MRT}^{*}$

Stroop Test 3b MRT

Choice Reaction Time TT
Face Recognition and Memory TT*

Face Recognition and Memory - Late MRT

Face Recognition and Memory - 1b MRT Stroop Test $1 \mathrm{~b} \mathrm{MRT}^{*}$

Stroop Test 3b MRT

Face Recognition and Memory TT*

Face Recognition and Memory - Late MRT

Face Recognition and Memory - 1b MRT

Stroop Test $1 \mathrm{~b} \mathrm{MRT}^{*}$

Stroop Test 3b MRT

Face Recognition and Memory TT*

Face Recognition and Memory - Late MRT

Face Recognition and Memory - 1b MRT

Stroop Test $1 \mathrm{~b}$ MRT*

Stroop Test 3b MRT

Choice Reaction Time TT
Face Recognition and Memory TT*

Face Recognition and Memory - Late MRT

Face Recognition and Memory - 1b MRT

Stroop Test $1 \mathrm{~b} M \mathrm{MRT}^{*}$

Stroop Test 3b MRT
$107,6928 \mathrm{~s}$

$81,9339 \mathrm{~s}$

$1581,329 \mathrm{~ms}$

$2180,144 \mathrm{~ms}$

$1254,086 \mathrm{~ms}$

$1948,673 \mathrm{~ms}$

$95,3231 \mathrm{~s}$

$67,7881 \mathrm{~s}$

$2054,938 \mathrm{~ms}$

$1223,623 \mathrm{~ms}$

$966,1565 \mathrm{~ms}$

$1181,825 \mathrm{~ms}$

$100,8276 \mathrm{~s}$

$73,8819 \mathrm{~s}$

$2373,4380 \mathrm{~ms}$

$1377,6960 \mathrm{~ms}$

$1205,17 \mathrm{~ms}$

$1237,347 \mathrm{~ms}$

$99,6133 \mathrm{~s}$

$113,6087 \mathrm{~s}$

$4082,4580 \mathrm{~ms}$

$1543,443 \mathrm{~ms}$

$942,0075 \mathrm{~ms}$

$1388,804 \mathrm{~ms}$

$82,9802 \mathrm{~s}$

$82,8587 \mathrm{~s}$

$3420,9110 \mathrm{~ms}$

$1630,6940 \mathrm{~ms}$

$996,9505 \mathrm{~ms}$

$1341,13 \mathrm{~ms}$

$96,9133 \mathrm{~s}$

$70,6400 \mathrm{~s}$

$1478,996 \mathrm{~ms}$

$1534,8910 \mathrm{~ms}$

$1011,6040 \mathrm{~ms}$

$1348,813 \mathrm{~ms}$

$85,7498 \mathrm{~s}$

$104,6703 \mathrm{~s}$

$2822,0950 \mathrm{~ms}$

$1910,1490 \mathrm{~ms}$

$941,3310 \mathrm{~ms}$

$1355,4500 \mathrm{~ms}$

$85,1279 \mathrm{~s}$

$78,1840 \mathrm{~s}$

$2689,3740 \mathrm{~ms}$

$1206,2970 \mathrm{~ms}$

$988,5155 \mathrm{~ms}$

$1101,8520 \mathrm{~ms}$
$137,0019 \mathrm{~s}$

$78,7689 \mathrm{~s}$

$1983,527 \mathrm{~ms}$

$1923,97 \mathrm{~ms}$

$1253,589 \mathrm{~ms}$

$1724,907 \mathrm{~ms}$

$130,7281 \mathrm{~s}$

$76,0310 \mathrm{~s}$

$1943,213 \mathrm{~ms}$

$1607,086 \mathrm{~ms}$

$1445,23 \mathrm{~ms}$

$1525,924 \mathrm{~ms}$

$117,2430 \mathrm{~s}$

$70,4697 \mathrm{~s}$

$2372,44 \mathrm{~ms}$

$1615,9570 \mathrm{~ms}$

$990,0635 \mathrm{~ms}$

$1277,844 \mathrm{~ms}$

$97,5163 \mathrm{~s}$

$109,1237 \mathrm{~s}$

$3199,1750 \mathrm{~ms}$

$1589,09 \mathrm{~ms}$

$949,4655 \mathrm{~ms}$

$1365,0810 \mathrm{~ms}$

$98,3556 \mathrm{~s}$

$73,5678 \mathrm{~s}$

$1935,131 \mathrm{~ms}$

$1910,888 \mathrm{~ms}$

$1389,82 \mathrm{~ms}$

$1581,593 \mathrm{~ms}$

$96,9233 \mathrm{~s}$

$70,6399 \mathrm{~s}$

$1534,89 \mathrm{~ms}$

$1478,9960 \mathrm{~ms}$

$1011,60 \mathrm{~ms}$

$1348,81 \mathrm{~ms}$

$88,1841 \mathrm{~s}$

$88,9504 \mathrm{~s}$

$1907,6610 \mathrm{~ms}$

$2033,2380 \mathrm{~ms}$

$924,9935 \mathrm{~ms}$

$1173,1820 \mathrm{~ms}$

$85,4049 \mathrm{~s}$

$66,4248 \mathrm{~s}$

$1653,5140 \mathrm{~ms}$

$1510,0410 \mathrm{~ms}$

$884,6790 \mathrm{~ms}$

$998,8005 \mathrm{~ms}$ 
TT: total time; MRT: median reaction time; $1 \mathrm{~b}$ : first block; $3 b$ : third block *showed a tendency to discriminate

It was observed that the median reaction time was able to distinguish the performance of subjects with stimulation on and off in incidental and delayed episodic memory, in addition to inhibitory control. The total time showed a tendency to distinguish between the two stages in episodic memory, while the average reaction time showed this same trend in processing speed and attention.

\section{DISCUSSION}

Cognitive changes in PD are explained by the fact that in addition to projections of the motor cortex, the striatum receives projections from cortical areas of association, in the sensitive cortex. Currently five circuits are well defined: the motor circuit, which originates in the supplementary motor area; the oculomotor circuit, originating in the frontal cortex in Broadmann's area; and the dorsolateral, lateral orbitofrontal and anterior cingulate circuits, all originating in the prefrontal cortex. All circuits share the same structures: frontal, striated lobe, GPi, nigra substance and thalamus. They are contiguous circuits, but they remain anatomically segregated along the neuronal loop of each circuit (Yang, 2016).

Of the above circuits, the three originating in prefrontal cortex apparently does not have a motor function. Therefore, it is not surprising that many clinical findings reveal the involvement of the basal ganglia nuclei in a wide variety of non-motor functions.

There are discussions in literature about the impairment of PD patients' performance in tasks involving implicit memory associating activation of the basal ganglia nuclei. In addition to it, there is also a deficit in tests of response inhibition, retention and manipulation of information and planning - activities that require working memory (Pavão, 2007). With the dopaminergic deficit and the degeneration of the neurons of the basal ganglia nuclei in the pathology of PD, this processing and the level of pre-activation of priming and procedural learning are impaired. Barbosa and Charchat-Fichman (2019b) brought results of several studies showing that executive functions were the most impaired function after DBS, however we cannot consider it something unique due to its characteristic of encompassing different aspects such as flexibility, monitoring and inhibitory 
control - aspects that showed a difference between the ON stages and OFF. Attention appears both discriminating the two stages and having a tendency to discrimination and, obviously, causing a reduction in latency in simple reaction time and with choice, as noted, but normally isn't much assessed (Barbosa and Charchat-Fichman, 2019b). The DBS is an instrument for controlling motor symptoms and its electrodes are placed in specific areas (subthalamic nucleus or GPi), involved in the motor circuit. Although they may get worse over the years (Pavão, 2007; Lewis et al, 2014), this may be the result of the disease evolution in a way that could occur, even more quickly, if the surgery had not happened.

More important than the functions themselves that appeared discriminating the two stages, but the time variables that were capable of that instead of the success and error variables, showing how much the influence of stimulation on the motor part, helps in the performance of cognitive tasks. CompCog subtests can be performed in order to reduce the impact that impaired physical ability can have on running a test. In addition, it is possible to record and compare the subject's performance in the highly efficient way during the course of the disease. A neuropsychological assessment prior to surgery is of great importance due to the fact that the presence of any cognitive impairment before surgery, especially in executive function and memory, should serve as an exclusion criterion and lower cognitive functioning at the baseline is predictive worse cognitive outcome after surgery.

Some of the limitations were the difficulty in evaluating these patients who had already undergone the surgery due to the fact that they had a large interval between one return and another to the neurosurgeon, when they returned. In addition, some did not want to turn off the device for fear of experiencing or increasing motor symptoms again. The future perspective is to investigate other aspects before and after surgery, such as mood and quality of life, to see if they are influenced by motor improvements and/or influence other aspects. Besides, it is important to increase the sample and replicate the analyzes. 


\section{REFERENCES}

Asahi T, Nakamichi N, Takaiwa A, Kashiwazaki D, Koh M, Dougu N, Takashima S, Tanaka K, Kuroda S. Impact of bilateral subthalamic stimulation on motor/cognitive functions in Parkinson's disease. Neurologia medico-chirurgica. 2014; 54(7): 529-536.

Barbosa ENB, Charchat-Fichman H. Systematic review of neuropsychological instruments used in subthalamic nucleus deep brain stimulation in Parkinson's disease patients. Dementia and Neuropsychologia. 2019a; 13(2): 162-171.

Barbosa ENB, Charchat-Fichman H. How is cognition in subthalamic nucleus deep brain stimulation Parkinson's disease patients? 2007-2017 Systematic Review. Dementia Neuropsycholia. 2019b; 13(4): 367-377.

Brucki SMD, Nitrini R, Caramelli P, Bertolucci PHF, Okamoto IH. Suggestions for utilization of the Mini-Mental State Examination in Brazil. Arquivos de Neuropsiquiatria. 2003; 61: 777-781.

Cardoso F. Tratamento da Doença de Parkinson. Arquivos de Neuropsiquiatria. 2015; 53(1): 1-10.

Cunha JA. Escalas Beck. São Paulo: Casa do Psicólogo; 2011.

de Paixão AO, de Jesus AVF, Silva FS, Messias GMS, Nunes TLGM, Nunes TLGM, Santos TB, Gomes MZ, Correia MGS. Doença de Parkinson: Uma Desordem Neurodegenerativa. Cadernos de Graduação - Ciências Biológicas e da Saúde. 2016; 1(16): 57-65

de Paula, Jonas \& Malloy-Diniz, Leandro. Manual RAVLT: Teste de Aprendizagem Auditivo-Verbal de Rey. 2018.

Ding W, Ding LJ, Li FF, Han Y, Mu L. Neurodegeneration and cognition in Parkinson's disease: a review. European Review for Medical and Pharmacological Sciences. 2015; 19: 2275-2281.

Houvenaghel JF, Jeune F, Dondaine T, Esquevin A, Robert G, Péron J, Haegelen C, Drapier S, Jannin P, Lozachmeur C, Argaud S, Duprez J, Drapier D, Vérin M, Sauleau P. Reduced Verbal Fluency following Subthalamic Deep Brain Stimulation: A Frontal-Related Cognitive Deficit? PLoS One. 2015; 10(10).

Krishnan S, Prasad S, Pisharady K, Sarma G, Sarma S, Kishore A. The decade after subthalamic stimulation in advanced Parkinson's disease: A balancing act. (Original Article)(Report) Neurology India. 2016; 64(1): 81

Malak ALSB, Vasconcellos LF, Pereira JS, Greca DV, Cruz M, Alves HVD, Spitz M, Charchat-Fichman H. Symptoms of depression in patients with mild cognitive impairmentn Parkinson's disease. Dementia and Neuropsychology, 2017; 11(2): 146-153.

Massano J, Garret C. Deep brain stimulation and cognitive decline in Parkinon's disease: a clinical review. Frontiers in Neurology. 2012; 3(66). 
Muslimovic D, Post B, Speelman JD, Schmand B. Cognitive profile of patients with newly diagnosed Parkinson disease. Neurology 2005; 65: 1239-1245.

Nascimento, E. (2005). WAIS-III: Escala de Inteligência Wechsler para Adultos manual técnico. São Paulo: Casa do Psicólogo.

Nasser JA, Falavigna A, Alaminos A, Bonatelli AP, Ferraz F. Estimulação Cerebral Contínua (DBS) Talâmica para Controle do Tremor. Arquivos de Neuropsiquiatria, 2002; 60(2-B): 429-434.

Nitrini R, Lefevre BH, Mathias SC, et al. Neuropsychological tests of simple application for diagnosing dementia. Arquivos de Neuropsiquiatria. 1994; 52: 457-465

Pavão R. Aprendizagem Implícita e Doença de Parkinson. Dissertação de mestrado - Instituto de Biociências da Universidade de São Paulo. Departamento de Fisiologia, 2007

Pham UHG, Andersson S, Toft M, Pripp AH, Konglund AE, Dietrichs E, Malt UF, Skogseid IM, Haraldsen IRH, Solbakk AK. Self-Reported Executive Functioning in Everyday Life in Parkinson's Disease after Three Months of Subthalamic Deep Brain Stimulation. Parkinson's Disease. 2015; 461453.

Sunderland T, Hill JL, Mellow AM, Lawlor BA, Gundersheimer J, Newhouse PA, Grafman JH. Clock drawing in Alzheimer's disease:A novel measure of dementia severity. Jounal of American Geriatric Society. 1989; 37(8): 725-729.

Svenningsson P, Westman E, Ballard C, Aarsland D. Cognitive impairment in patients with Parkinson's disease: diagnosis, biomarkers, and treatment. The Lancet Neurology, 2012; 11(8): 697-707.

Tang V, Zhu C, Chan D, Lau C, Chan A, Mok V, Yeung J, Poon W. Evidence of improved immediate verbal memory and diminished category fluency following STN-DBS in Chinese-Cantonese patients with idiopathic Parkinson's disease. Neurological Sciences. 2015; 36(8): 1371-1377.

Tremblay C, Macoir J, Langlois M, Cantin L, Prudhomme M, Monetta L. The effects of subthalamic deep brain stimulation on metaphor comprehension and language abilities in Parkinson's disease. Brain and Language. 2015; 141: 103109.

Vasconcellos LF, et al. Correlation of MRI Visual Scales with Neuropsychological Profile in Mild Cognitive Impairment of Parkinson's Disease. Parkinson's Disease, 2017: 7380102.

Ventre-Dominey J, Mollion H, Thobois S, Broussolle E. Distinct effects of dopamine vs STN stimulation therapies in associative learning and retention in Parkinson disease. Behavioral Brain Research. 2016; 302: 131-141.

Vonberg I, Ehlen F, Fromm O, Kühn A, Klostermann F. Deep Brain Stimulation of the Subthalamic Nucleus Improves Lexical Switching in Parkinsons Disease Patients. PLoS One. 2016; 11(8). 
Wang XP, et al. Cognitive Changes and Promotion in Parkinson's Disease. Parkinson's Disease, 2018, 2p.

Yang et al. Parkinson's Disease and Cognitive Impairment. Parkinson's Disease. 2016; 8 . 


\section{FINAL CONSIDERATIONS}

The neuropsychological evaluation provides information about the interaction between the neurological, psychological and behavioral functioning of the patient, thus defines the clinical management and its subsequent results. The analysis of the neuropsychological and neuropsychiatric aspects is well described in the literature and they serve both in screening and in the evolution of the patients undergoing surgery (VAZQUEZ et al, 2013).

The general purpose of this thesis was to think and develop innovative perspectives for diagnosis and treatment and, in this context, it was possible to validate a computerized instrument for a neuropsychological assessment of PD patients in a sensitive and specific way and we verified, at least in this small sample, that the use of DBS does not compromise the cognitive functioning of patients who underwent this intervention.

The first part of this work focused on understanding the neuropsychological profile of patients with PD who underwent DBS implantation. The systematic review focused on observing which instruments were used to assess these subjects (BARBOSA and CHARCHAT-FICHMAN, 2019a) and whether there were changes in their cognitive profile (BARBOSA and CHARCHAT-FICHMAN, 2019b). In clinical settings, these findings have great impact because it can be established as a neuropsychological assessment protocol, or that facilitates the creation of standards and the comparison between different specifications with specificities. This can guide both health professionals and researchers to better understand how the cognitive profile of these patients occurs and identify, as soon as possible, when the onset of the compromise begins

The second part of this work focused on put into practice the use of the neuropsychological assessment protocol in PD patients from a public hospital in the state of Rio de Janeiro as well as clinically validate a computerized neuropsychological battery for this population. In addition, take advantage of this computerized neuropsychological battery and compare two moments of patients with PD who have DBS: ON and OFF stages, on and off stimulation, to see if there is any influence of surgery on the cognitive profile of this group. In clinical settings, these findings allow the use of a new instrument, with high sensitivity 
and specificity to assist in the identification of the disease, in addition to offering very detailed and precise information regarding the subject's cognitive performance - which was perceived when used, bringing average data on reaction time, learning and processing speed.

In conclusion, this thesis shows the importance of studying and developing innovative methods to identify and treat PD due to its wide reach currently in the population and the need for improvement in the way it has been worked. The risk for the evolution of a cognitive impairment in different cognitive functions for a MCI and hence for dementia is great and it is necessary to neuropsychological assessment of these patients periodically in order to prevent and remedy, as soon as possible. 


\section{REFERENCES}

AARSLAND D, et al. Range of neuropsychiatric disturbances in patiens with Parkinson's disease. Journal of Neurology, Neurosurgery and Pshychiatry, 2009, v. 67, p. 492-496.

AGUILAR OM, SOTO CA, Esguerra M. Cambios neuropsicológicos asociados a estimulación cerebral profunda en enfermedad de parkinson: revisión teórica. Suma Psicológica, 2011, v. 18, n. 2, p. 89-98.

ALBERTS JL. Bilateral subthalamic stimulation impairs cognitive-motor performance in Parkinson's disease patients. Brain, 2008, v. 131, n. 12, p. 33483360 .

ASAHI $\mathrm{T}$ et al. Impact of bilateral subthalamic stimulation on motor/cognitive functions in Parkinson's disease. Neurologia medico-chirurgica, 2014, v. 54, n. 7, p. 529-536.

ATALAIA-SILVA KC, LOURENÇO RA. Tradução, adaptação e validação de construto do Teste do Relógio aplicado entre idosos no Brasil. Revista de Saúde Pública, 2008, v. 42, n. 5, p. 930-937.

BARBOSA ENB, CHARCHAT-FICHMAN H. Neuropsychological assessment contribuition to Mild Cognitive Impairment (MCI): methodological issues. 144p. Dissertação de Mestrado - Departamento de Psicologia, Pontifícia Universidade Católica do Rio de Janeiro, 2015.

BARBOSA ENB, CHARCHAT-FICHMAN. Systematic review of neuropsychological instruments used in subthalamic nucleus deep brain stimulation in Parkinson's disease patients. Dementia and Neuropsychologia, 2019, v. 13, n. 2, p. 162-171.

BARBOSA ENB, CHARCHAT-FICHMAN, H. How is cognition in subthalamic nucleus deep brain stimulation Parkinson's disease patients? Dementia \& neuropsychologia, 2019, v. 13, n. 4, p. 367-377.

BARBOSA, MT; CARDOSO, F. Prevalência da Doença de Parkinson e outros tipos de Parkinsonismo em idosos: estudo de Bambuí. Universidade de São Paulo, São Paulo, 2005.

BADDELEY, A. Working Memory: Theoris, Models and Controversies. Annual Review of Psychology. 2012, v. 63, p. 1-29.

BROWN RG, MACCARTHY B. Psychiatric morbidity in patients with Parkinson's disease. Psychological Medicine. 1990, v. 20, n. 1, p. 77-87.

BUTCHER JN, PERRY J, HAHN J. Computers in clinical assessment: Historical developments, present status, and future challenges. Journal of Clinical Psychology. 2004, v. 60, n. 3, p.331-345. 
CAPOVILLA AGS. Desenvolvimento e validação de instrumentos neuropsicológicos para avaliar funções executivas. Avaliação Psicológica, 2006, v. 5 , n. 2, p. 239-241.

CARDOSO F. Tratamento da Doença de Parkinson. Arquivos de Neuropsiquiatria, 1995, v. 53, n. 1, p. 1-10.

CASTELLI et al. Apathy and verbal fluency in STN-stimulated PD patients. Journal of Neurology, 2007, v. 254, n. 9, p. 1238-1243.

CASTELLI et al. Motor and cognitive outcome in patients with Parkinson's disease 8 years after subthalamic implants. Parkinsonism and Related Disorders, 2010, v. 16, n. 2, p. 115-118.

CERNICH AN, BRENNANA DM, BARKER LM, BLEIBERG J. Sources of error in computerized neuropsychological assessment. Archives of Clinical Neuropsychology, 2008, v. 22S, p. S39-S48.

CHARCHAT, H. (1999). Desenvolvimento de uma bateria de testes neuropsicológicos computadorizados para o diagnóstico precoce da Doença de Alzheimer. Dissertação de Mestrado não-publicada. Curso de Pós-Graduação de Neurociências e Comportamento, Instituto de Psicologia, Universidade de São Paulo. São Paulo, SP.

CHARCHAT H, NITRINI R, CARAMELLI P, SAMESHIMA K. Investigação de Marcadores Clínicos dos Estágios Iniciais da Doença de Alzheimer com Testes Neuropsicológicos Computadorizados. Psicologia: Reflexão e Crítica, 2001, v. 14, n. 2, p. 305-316.

CILIA R, et al.. Brain networks underlining verbal fluency decline during STNDBS in Parkinson's disease: An ECD-SPECT study. Parkinsonism and Related Disorders, 2007, v. 13, n. 5, p. 290-294.

CHRISCHILLES EA, et al. Linking clinical variables to health-related quality of life in Parkinson's disease. Parkinsonism Related Disorders, 2003, v. 8, p. 199209.

DANIELS C, et al. Risk factors for executive dysfunction after subthalamic nucleus stimulation in Parkinson's disease. Movement Disorders, 2010, v. 25, n. 11, p. 1583-1589.

DE BOER AGEM, et al. Disease-specific quality of life: is it one construct? Quality of Life Research, Oxford, 1998, v. 7, p. 135-142.

DE LAU LM, BRETELER MMB. Epidemiology of Parkinson's Disease. The Lancet Neurology, 2006, v. 5, p. 525-535.

DE OLIVEIRA MD, MACHADO DMS. Cognitive decline in Parkinson's disease: contributions of Neuropsychology. Revista de Medicina de Minas Gerais, 2014, v. 24, n. 3, p. 349-354

DE PAIXÃO AO, et al. Doença de Parkinson: Uma Desordem Neurodegenerativa. Cadernos de Graduação - Ciências Biológicas e da Saúde, 2016, v. 1, n. 16, p. 57-65. 
DING W, et al. Neurodegeneration and cognition in Parkinson's disease: a review. European Review for Medical and Pharmacological Sciences, 2015, v. 19, p. $2275-2281$.

DRIVER JA, LOGROSCINO G, GAZIANO JM, KURTH T. Incidence and remaining lifetime risk of Parkinson disease in advanced age. Neurology. 2009 , v. 72 , n. 5 , p. $432-438$.

FASANO A, et al. A Neuropsychological changes 1-year after subthalamic DBS in PD patients: A prospective controlled study. Brain, 2010, v. 133, n. 9, p. 2664-2676, 2010.

FICHMAN HC, et al. Age and educational level effects on the performance of normal elderly on category verbal fluency tasks. Dementia and Neuropsychology, 2009, v. 3, n. 1, p. 49-54.

GALHARDO MMAM, DO AMARAL AKFJ, VIEIRA ACC. Caracterização dos distúrbios cognitivos na Doença de Parkinson. Revista CEFAC, 2009, v. 11, n. 2, p. 251-257.

GROVER S, et al. Psychiatric aspects of Parkinson's disease. Journal of Neuroscience Rural Practice, 2015, v. 6, n. 1, p. 65-76.

HARIZ M. Deep brain stimulation plus best medical therapy versus best medical therapy alone for advanced Parkinson's disease. Lancet Neurology, 2009, v. 8, n. 3, p. 223-224.

HELUANI AS. Cognição, humor e atividades funcionais em pacientes com doença de Parkinson submetidos à estimulação cerebral profunda bilateral em núcleo subtalâmico. 2014. Dissertação de mestrado - Faculdade de Medicina, Universidade de São Paulo.

HEO JH, et al. The effects of bilateral Subthalamic Nucleus Deep Brain Stimulation (STN DBS) on cognition in Parkinson disease. Journal of the Neurological Sciences, 2008, v. 273, n. 1, p. 19-24.

HOUVENAGHEL JF, et al. Reduced Verbal Fluency following Subthalamic Deep Brain Stimulation: A Frontal-Related Cognitive Deficit? PLoS One, 2015, v. 10, n. 10.

ISRAELI-KORN S et al. Subthalamic Nucleus Deep Brain Stimulation Does Not Improve Visuo-Motor Impairment in Parkinsons Disease. PLoS One, 2013, v. 8, n. 6 .

JOHNSON DR, et al. Reliability and construct validity of the Automated Neuropsychological Assessment Metrics (ANAM) mood scale. Archives of Clinical Neuropsychology, 2008, v. 23, p. 73-85.

JUNIOR AS, CABRAL ACJ. Alterações Psiquiátricas na Doença de Parkinson. In Neuropsiquiatria geriátrica. São Paulo: Editora Atheneu, 2000.

KIM HJ, et al. Initial cognitive dip after subthalamic deep brain stimulation in Parkinson disease. Journal of Neurology, 2013, v. 260, n. 8, p. 2130-2133. 
KLEMPIROVA O. et al. Deep brain stimulation of the subthalamic nucleus and cognitive functions in Parkinson's disease. Prague Medical Report, 2007, v. 108, n. 4 , p. $315-323$.

KRISHNAN S. et al. The decade after subthalamic stimulation in advanced Parkinson's disease: A balancing act. Neurology India, 2016, v. 64, n. 1, p. 81.

LANG AE, LOZANO AM. Parkinson's disease. First of two parts. New England Journal of Medicine, 1998, v. 339, n. 15, p. 1044-1053.

LEWIS CJ, et al. Parkinson's disease patients with subthalamic stimulation and carers judge quality of life differently. Parkinsonism Related Disorders, 2014, v. 20, n. 5 , p. $514-519$.

LOURENÇO RA, VERAS RP, RIBEIRO PCC. Confiabilidade teste-reteste do mini-exame do estado mental em uma população idosa assistida em uma unidade ambulatorial de saúde. Revista Brasileira de Geriatria e Gerontologia, 2008, v. 11, p. 7-16.

LUEKEN U, et al. Impaired performance on the Wisconsin Card Sorting Test under left- when compared to right-sided deep brain stimulation of the subthalamic nucleus in patients with Parkinson's disease. Journal of Neurology, 2008; v. 255, n. 12, p. 1940-1948.

MACHADO FA, REPPOLD CT. The effect of deep brain stimulation on motor and cognitive symptoms of Parkinson's disease - A literature review. Dementia and Neuropsychology, 2015, v. 9, n. 1, p. 24-31.

MACUGLIA GR, RIEDER CRM, DE ALMEIDA RMM. Funções executivas na doença de Parkinson: Revisão da Literatura. PSICO. 2012, v. 43, n. 4, p. 552561 .

MARCHI KC. Impacto da depressão na qualidade de vida e na adesão a levodopa em pacientes com Doença de Parkinson. Ribeirão Preto, 2011. 69 p. Dissertação de Mestrado apresentada à Faculdade de Enfermagem de Ribeirão Preto da Universidade de São Paulo

MARKSER A, et al. Deep brain stimulation and cognitive decline in Parkinson's disease: The predictive value of electroencephalography. Journal of Neurology, 201 , v. 262 , n. 10 , p. $2275-2284$.

MASSANO J, GARRET C. Deep brain stimulation and cognitive decline in Parkinon's disease: a clinical review. Frontiers in Neurology, 2012, v. 3, n. 66.

MATTOS P. Uso de testes computadorizados em neuropsicologia. Em: Gagliardi RJ, Reimao R (Org.). Clínica Neurológica, São Paulo: Lemos, 1998, p. 319-322.

MELO LM, BARBOSA ER, CARAMELLI P. Declínio cognitivo e demência associados à doença de Parkinson: características clínicas e tratamento. Revista de Psiquiatria Clínica, 2007, v. 34, n. 4, p. 176-183.

NAVARRO-PETERNELLA FM, MARCON SS. Qualidade de vida de indivíduos com Parkinson e sua relação com tempo de evolução e gravidade da doença. Revista Latino-Americana de Enfermagem, 2012, v. 20, n. 2, p. 384-391. 
NASSER JA et al. Estimulação Cerebral Contínua (DBS) Talâmica para Controle do Tremor. Arquivos de Neuropsiquiatria, 2002, v. 60, n. 2-B, p.429-434.

NOMBLELA C, et al. Genetic impact on cognition and brain function in newly diagnosed Parkinson's disease: ICICLE-PD study. Brain, 2016, v. 137, p. 26252631.

PAVÃO R. Aprendizagem Implícita e Doença de Parkinson. 2007. Dissertação de mestrado - Instituto de Biociências, Universidade de São Paulo. Departamento de Fisiologia, São Paulo, 2007.

PHAM UHG, et al. Self-Reported Executive Functioning in Everyday Life in Parkinson's Disease after Three Months of Subthalamic Deep Brain Stimulation. Parkinson's Disease, 2015.

POLIAKOFF E, SMITH-SPARK JH. Everyday cognitive failures and memory problems in Parkinson's patients without dementia. Brain Cognition, 2008, v. 67, n. 3, p. 340-350.

POSTUMA RB, et al. MDS clinical diagnostic criteria for Parkinson's disease. Movement Disorders, 2015, v. 30, n. 12.

RITA HJP. REIS AI. Dissociação da memória explícita e implícita da Doença de Parkinson. 2012. 56p. Dissertação (Mestrado) - Human Sciences and Social College. Universidade do Algarve.

RITSNER MS, BLUMENKRANTZ H, DUBINSKY T, DWOLATZKY T. The detection of neurocognitive decline in schizophrenia using the Mindstreams Computerized Cognitive Test Battery. Schizophrenia Research, 2006, v. 82, p. 39-49.

RIZZONE MG, et al. Long-term outcome of subthalamic nucleus DBS in Parkinson's disease: From the advanced phase towards the late stage of the disease? Parkinsonism and Related Disorders, 2014, v. 20, n. 4, p. 376-381.

SCHATZ P, BROWNDYKE J. Applications of Computer-based Neuropsychological Assessment. Journal of Head Trauma Rehabilitation, 2002, v. 17, n. 5, p. 395-410.

SCHNEIDER JS, SENDEK S, YANG C. Relationship between Motor Symptoms, Cognition, and Demographic Characteristics in Treated Mild/Moderate Parkinson's Disease. PLoS One, 2015, v. 10, n. 4, p. 1-11.

STELLA F, et al. Early impairment of cognitive functions in Parkinson's disease. Arquivos de Neuro-Psiquiatria, 2007, v. 65, 2b, p. 406-410.

TANG V, et al. Evidence of improved immediate verbal memory and diminished category fluency following STN-DBS in Chinese-Cantonese patients with idiopathic Parkinson's disease. Neurological Sciences,. 2015, v. 36, n. 8, p. 13711377.

TEMEL Y, et al. The functional role of the subthalamic nucleus in cognitive and limbic circuits. Progress in Neurobiology. 2005, v. 76, n. 6, p. 393-413. 
TOULOUSE A, SULLIVAN AM. Progress in Parkinson's Disease - Where do we stand? Progress in Neurobiology. 2008, v. 85, n. 4, p. 376-392.

TREMBLAY C, et al. The effects of subthalamic deep brain stimulation on metaphor comprehension and language abilities in Parkinson's disease. Brain and Language. 2015, v. 141, p. 103-109.

VAN WOUWE NC, et al. Deep Brain Stimulation of the Subthalamic Nucleus Improves Reward-Based Decision-Learning in Parkinson's Disease. Frontiers in Human Neuroscience, 2011, v. 5.

VASCONCELLOS LF, et al. Correlation of MRI Visual Scales with Neuropsychological Profile in Mild Cognitive Impairment of Parkinson's Disease. Parkinson's Disease, 2017.

VÁSQUEZ RS, et al. Estimulación Cerebral Profunda y Enfermedad de Parkinson: Documento Instructivo para el Manejo Multidisciplinario en el Hospital Regional Dr. Teodoro Maldonado Carbo. Revista Ecuateriana de Neurologia, 2013, v. 22, n. 1-3.

VENTRE-DOMINEY J, et al. Distinct effects of dopamine vs STN stimulation therapies in associative learning and retention in Parkinson disease. Behavioural Brain Research, 2016, v. 302, p. 131-141.

VONBERG I, et al. Deep Brain Stimulation of the Subthalamic Nucleus Improves Lexical Switching in Parkinsons Disease Patients. PLoS One. v. 11, n. 8.

WANG XP, et al. Cognitive Changes and Promotion in Parkinson's Disease. Parkinson's Disease, 2018, p. 1-2.

WERNECK ALS. Doença de Parkinson: Etiopatogenia, Clínica e Terapêutica. Revista Hospital Universitário Pedro Ernesto, 2010, v. 9, p. 10-19.

WILD K, et al. Status of computerized cognitive testing in aging: A systematic review. Alzheimer's \& Dementia, 2008, v. 4, p. 428-437.

WILLIAMS A, et al. Deep brain stimulation plus best medical therapy versus best medical therapy alone for advanced Parkinson's disease (PD SURG trial): a randomised, open-label trial. Lancet Neurology, 2010, v. 9, p. 581-591.

WITT K, et al. Neuropsychological and psychiatric changes after deep brain stimulation for Parkinson's disease: a randomised, multicentre study. Lancet Neurology, 2008, v. 7, n. 7, p. 605-614.

WOO H. Computerized Neuropsychological Assessments. CNS Spectrums, 2008, v. 13, n. 10 Suppl 16, p. 14-17.

YÁGUEZ L, et al. Cognitive predictors of cognitive change following bilateral subthalamic nucleus deep brain stimulation in Parkinson's disease. Journal of Clinical Neuroscience, 2014, v. 21, n. 3, p. 445-450. 
YORK MK, et al. Relationship between neuropsychological outcome and DBS surgical trajectory and electrode location. Journal of the Neurological Sciences. v. 287 , n. 1, p. 159-171, 2009.

ZANGAGLIA R, et al. Deep brain stimulation and cognitive functions in Parkinson's disease: A three-year controlled study. Movement Disorders, 2009, v. 24, n. 11, p. 1621-1628. 